(11) Nordic Council of Ministers

\title{
Particle emissions \\ in Belarus and in the Nordic countries
}

Emission inventories and integrated assessment modelling of black carbon and PM2.5 



\section{Particle emissions in Belarus and in the Nordic countries}

Emission inventories and integrated assessment modelling of black carbon and PM2.5

Sergey Kakareka, Hanna Malchykhina, Olga Krukowskaya, Katarina Yaramenka, Karin Kindbom, Ingrid Mawdsley, Stefan Åström, Ole-Kenneth Nielsen, Marlene Plejdrup, Jesper Bak, Kristina Saarinen and Mikko Savolahti,

TemaNord 2018:544 
Particle emissions in Belarus and in the Nordic countries

Emission inventories and integrated assessment modelling of black carbon and PM2.5

Sergey Kakareka, Hanna Malchykhina, Olga Krukowskaya, Katarina Yaramenka, Karin Kindbom, Ingrid

Mawdsley, Stefan Åström, Ole-Kenneth Nielsen, Marlene Plejdrup, Jesper Bak, Kristina Saarinen and Mikko Savolahti,

ISBN 978-92-893-5766-1 (PRINT)

ISBN 978-92-893-5767-8 (PDF)

ISBN 978-92-893-5768-5 (EPUB)

http://dx.doi.org/10.6027/TN2018:544

TemaNord 2018:544

ISSN $0908-6692$

Standard: PDF/UA-1

ISO 14289-1

(c) Nordic Council of Ministers 2018

Print: Rosendahls

Printed in Denmark

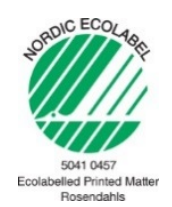

\section{Disclaimer}

This publication was funded by the Nordic Council of Ministers. However, the content does not necessarily reflect the Nordic Council of Ministers' views, opinions, attitudes or recommendations.

\section{Rights and permissions}

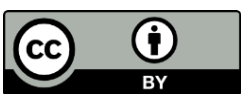

This work is made available under the Creative Commons Attribution 4.0 International license (CC BY 4.0) https://creativecommons.org/licenses/by/4.0.

Translations: If you translate this work, please include the following disclaimer: This translation was not produced by the Nordic Council of Ministers and should not be construed as official. The Nordic Council of Ministers cannot be held responsible for the translation or any errors in it.

Adaptations: If you adapt this work, please include the following disclaimer along with the attribution: This is an adaptation of an original work by the Nordic Council of Ministers. Responsibility for the views and opinions expressed in the adaptation rests solely with its author(s). The views and opinions in this adaptation have not been approved by the Nordic Council of Ministers. 
Third-party content: The Nordic Council of Ministers does not necessarily own every single part of this work. The Nordic Council of Ministers cannot, therefore, guarantee that the reuse of third-party content does not infringe the copyright of the third party. If you wish to reuse any third-party content, you bear the risks associated with any such rights violations. You are responsible for determining whether there is a need to obtain permission for the use of third-party content, and if so, for obtaining the relevant permission from the copyright holder. Examples of third-party content may include, but are not limited to, tables, figures or images.

Any queries regarding rights and licences should be addressed to:

Nordic Council of Ministers/Publication Unit

Ved Stranden 18

DK-1061 Copenhagen $\mathrm{K}$

Denmark

Phone +4533960200

pub@norden.org

Nordic co-operation

Nordic co-operation is one of the world's most extensive forms of regional collaboration, involving Denmark, Finland, Iceland, Norway, Sweden, and the Faroe Islands, Greenland and Åland.

Nordic co-operation has firm traditions in politics, economics and culture and plays an important role in European and international forums. The Nordic community strives for a strong Nordic Region in a strong Europe.

Nordic co-operation promotes regional interests and values in a global world. The values shared by the Nordic countries help make the region one of the most innovative and competitive in the world.

\section{The Nordic Council of Ministers}

Nordens Hus

Ved Stranden 18

DK-1061 Copenhagen K, Denmark

Tel.: +453396 o200 www.norden.org

Download Nordic publications at www.norden.org/nordpub 



\section{Contents}

Preface

1. Background and introduction

2. $\mathrm{PM}_{2.5}$ and $\mathrm{BC}$ emission inventories and projections in Belarus .................................... 13

$2.1 \quad \mathrm{PM}_{2.5}$ emission inventories and projections in Belarus ....................................

2.2 Black carbon emission inventory in Belarus ..................................................... 20

2.3 $\mathrm{PM}_{2.5}$ and $\mathrm{BC}$ emission inventories and projections in Belarus - further improvement

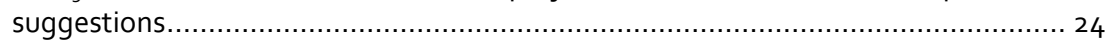

3. $\mathrm{PM}_{2.5}$ and $\mathrm{BC}$ emission inventories in the Nordic countries .....................................27

3.1 Black carbon emission inventories and projections in the Nordic countries -

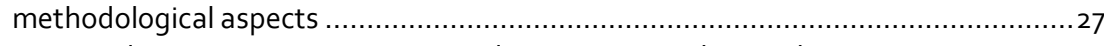

3.2 $\mathrm{PM}_{2.5}$ and $\mathrm{BC}$ emission inventories and projections in the Nordic countries - summary

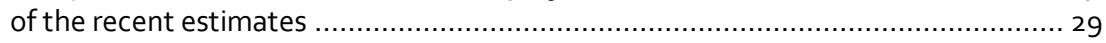

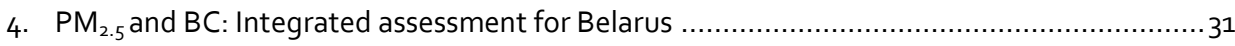

4.1 Baseline emissions, MFR and emission reduction potentials ................................ 31

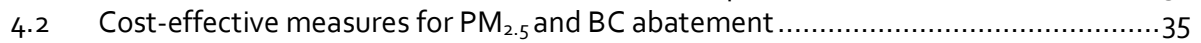

4.3 Gap closure in the stationary sector - possible ambition levels for policy decisions . 40

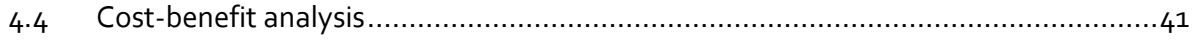

4.5 Alternative emission factor datasets for key emitting sources in Belarus................. 44

4.6 $\mathrm{PM}_{2.5}$ and $\mathrm{BC}$ integrated assessment for Belarus - conclusions........................... 48

5. $\mathrm{PM}_{2.5}$ and $\mathrm{BC}$ : Integrated assessment for the Nordic countries...................................51

5.1 Baseline emissions, MFR and emission reduction potentials ................................ 51

5.2 Cost-effective measures for $\mathrm{PM}_{2.5}$ and $\mathrm{BC}$ abatement..................................... 52

5.3 Gap closure in the stationary sector - possible ambition levels for policy decisions .54

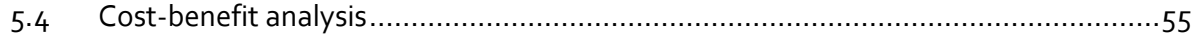

5.5 Transboundary effects from the implementation of MFR scenarios ...................... 56

5.6 Alternative BC emission factor datasets for heating stoves in the Nordic countries .. 57

$5.7 \quad \mathrm{PM}_{2.5}$ and $\mathrm{BC}$ integrated assessment for the Nordic countries - conclusions............ 58

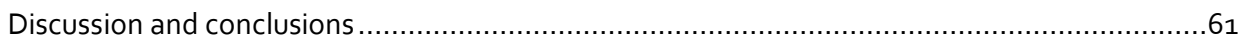

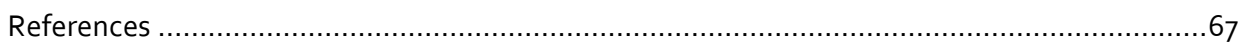

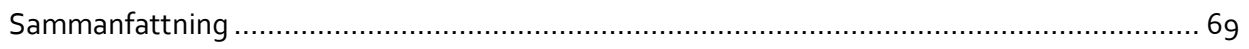

Annex 1. Emission factors used in the $\mathrm{PM}_{2.5}$ inventories in Belarus ...................................... 71

Annex 2. National statistic on TSP emissions in Belarus in 2014 ...................................... 73

Annex 3. National guidelines for calculation of soot emissions ........................................75

Annex 4. $\mathrm{PM}_{2.5}$ cost curves for stationary emission sources - specification of measures .............77

Annex 5 . Black carbon cost curve for stationary emission sources in Belarus - specification of

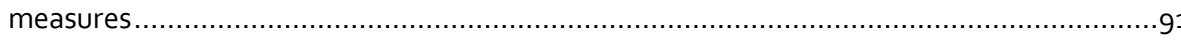

Annex 6. Alternative emission factors sets for industrial processes in Belarus ....................... 95

Annex 7. Emission factors for heating stoves...........................................................97

Annex 8. Baseline emissions and emission reduction potentials in the Nordic countries in 2030

Annex 9. Ranking of black carbon reduction measures for stationary emission sources by marginal costs, the Nordic countries ................................................................ 101

Annex 10. Transboundary effects from the implementation of MFR scenarios......................109 



\section{Preface}

The present report summarizes the results of the multilateral Nordic-Belarus cooperation project "Development of $\mathrm{PM}_{2.5}$ and black carbon emission inventory and GAINS modelling in Belarus - sharing Nordic experience and strengthening cooperation". The project was financed by the Nordic Council of Ministers and partly by the in-kind work of the national experts.

The overall goal of the project is to stimulate decision-makers in Belarus to prioritize abatement measures aimed at black carbon in their efforts to reduce emissions of $\mathrm{PM}_{2.5}$ as encouraged in the Gothenburg protocol under the UNECE CLRTAP. To reach this purpose and in order to build up scientific basis necessary for further policy development, a comprehensive analysis of $\mathrm{PM}_{2.5}$ and black carbon emissions, emission reduction potentials and cost-effective abatement measures in Belarus has been conducted. The present report summarizes the results of the analysis.

The main part of the analysis included in the project has been conducted by national experts from the Institute for Nature Management in Belarus, with methodological support provided by the three participating Nordic countries Denmark, Finland and Sweden.

The project team would like to thank Robert Sander from the International Institute for Applied System Analysis (IIASA) for quick and efficient technical support regarding GAINS model issues.

Stockholm 2018-08-06

Sergey Kakareka, Hanna Malchykhina, Olga Krukowskaya, Institute for Nature Management of the National Academy of Sciences, Belarus

Katarina Yaramenka, Karin Kindbom, Ingrid Mawdsley, Stefan Åström, IVL Swedish Environmental Research Institute, Sweden

Ole-Kenneth Nielsen, Marlene Plejdrup, Jesper Bak, Aarhus University, Denmark Kristina Saarinen, Mikko Savolahti, Finnish Environment Institute SYKE, Finland 



\section{Summary}

The purpose of the project is to stimulate decision-makers in Belarus to prioritize abatement measures aimed at black carbon in their efforts to reduce emissions of $\mathrm{PM}_{2.51}$ as encouraged in the Gothenburg protocol under the United Nations Economic Commission for Europe, Convention on Long-range Transboundary Air Pollution (UNECE CLRTAP). To reach this purpose and in order to build up scientific basis necessary for further policy development, a comprehensive analysis of $\mathrm{PM}_{2.5}$ and black carbon emissions, emission reduction potentials and cost-effective abatement measures in Belarus have been conducted. The present report summarizes the results of the analysis.

The report presents two main parts of the conducted analysis: a part focused on the emission inventories, and a part summarizing the results of the integrated assessment modelling. The main focus is on analysis for Belarus; however, a range of modelling results have been obtained for the three participating Nordic countries -Denmark, Finland and Sweden. Years 2014-2015 are considered to represent the current situation while for the future scenarios 2030 is chosen as a target year.

The report covers several important aspects of the integrated analysis of particle emissions in Belarus (and to a certain extent in the Nordic countries) and provides scientists and decision-makers in Belarus with the following results:

- An improved emission inventory of $\mathrm{PM}_{2.5}$ following the methodology specified in the EMEP/EEA Air Pollutant Emission Inventory Guidebook (2013);

- The first black carbon emission inventory in Belarus;

- Estimates of baseline emissions of $\mathrm{PM}_{2.5}$ and $B C$ in 2030, emissions according to the maximum feasible emission reduction (MFR) scenario, and emission reduction potentials;

- Separate sets of the most cost-effective measures to reduce emissions of $\mathrm{PM}_{2.5}$ and $B C$ in Belarus - either to a desired level of emissions or within a specified budget - including detailed specification of each measure's emission reduction potential and marginal costs;

- Sector-specific and total technical costs for several ambition levels regarding potential emission reductions in a range between the baseline and the MFR emissions (a gap closure approach);

- Estimates of societal benefits and cost-effectiveness of implementation of emission reduction measures at different ambition levels;

- Analysis of transboundary pollution regarding particle emissions (populationweighted concentrations of $\mathrm{PM}_{2.5}$, related health effects and their valuations);

- Analysis of the impact of using alternative (based on the EMEP/EEA Guidebook) emission factors for certain key emitting sectors. 
According to the improved emission inventory, 33.4 ktonnes of $\mathrm{PM}_{2.5}$ was emitted in Belarus in 2014. Total national black carbon emissions during the same year are estimated at 3.87 ktonnes, originating mostly from residential wood combustion.

The integrated assessment modelling results estimate the total baseline emissions of $\mathrm{BC}$ in Belarus at 3.6 ktonnes, and emissions of $\mathrm{PM}_{2.5}$ at 52 ktonnes in 2030. The total emission reduction potential (emission difference between the baseline scenario and the maximum feasible reduction scenario - MFR) is estimated at 35.2 ktonnes for $\mathrm{PM}_{2.5}$ and 2.5 ktonnes for BC. In general, high emission reduction potentials are observed in sectors with the largest contribution to the total emissions, implying that mitigation efforts should be taken in the key source sectors.

Cost curves for $\mathrm{PM}_{2.5}$ and for $\mathrm{BC}$ have been compiled. A cost curve lists all measures necessary to close the gap between the emission levels corresponding to the baseline and MFR scenarios, in the order of their cost-effectiveness, starting with the lowest marginal costs. The most cost-effective measures for $\mathrm{BC}$ emissions in Belarus according to this analysis are end-of-pipe solutions (electrostatic precipitators, high-efficiency dedusters) for industrial furnaces and residential boilers, as well as replacement of conventional boilers with improved devices. These measures would result in significant black carbon emission reductions at relatively low costs.

The total (brutto) societal benefits from full implementation of the MFR scenario in Belarus are estimated at between EUR 600 (VOLY - Value of a Life Year lost) and 2,100 (VSL - Value of Statistical Life)) million annually, depending on the chosen valuation metric. About half of it corresponds to avoided negative impacts on population health in the neighbouring countries. In case VOLY is used as the main valuation metric, emission reductions in Belarus appear to be cost-effective (in terms of in-country benefits exceeding costs) even at the high level of ambition - but not at the MFR level. If benefits are valued in VSL, emission reductions even at the MFR level would be cost-effective the net benefit within the country in this case is estimated at EUR 220 million. Only health effects are included in the valuation of societal benefits in this study.

Analysis of the transboundary effects, performed by consequently reducing emissions down to the MFR level in each country, indicates that particle emissions in each of the considered countries affect population in the other countries, with the exception of Belarus-to-Denmark and Finland-to-Denmark cases (there is either no effect or too small effect to be captured in the GAINS model). Reductions of particle emissions in Belarus would affect population in other European countries (mostly Russia, Ukraine and Poland) almost as much as the country's own population.

In order to investigate the effect of the emission factors on the emissions and emission reduction potentials, simulation runs with a set of alternative emission factors (based on default values provided in the EMEP/EEA Guidebook) for key sources have been done. For Belarus, applying the alternative emission factors for $\mathrm{PM}_{2.5}$ results in significantly (by $\sim 21$ ktonnes) lower emissions than using current GAINS emission factors.

The results of this study can be used as a scientific basis for decision-making in the development of national strategies to reduce particle emissions in Belarus (and to a certain extent in the Nordic countries), and for negotiations within international agreements, such as the revised Gothenburg protocol under the UNECE CLRTAP. 


\section{Background and introduction}

Black carbon (BC), or soot, is a component of fine particulate matter $\left(\mathrm{PM}_{2.5}\right)$ and one of the short-lived climate pollutants (SLCP) that has been paid much attention to in the last years. Black carbon is a climate pollutant absorbing solar radiation, but it also causes negative effects on people's health. This is exacerbated by long-distance transportation of black carbon, which makes the substance a transboundary problem. The substance is included in the revised Gothenburg protocol under the United Nations Economic Commission for Europe, Convention on Long-range Transboundary Air Pollution (UNECE CLRTAP). As stated in the amendment to the protocol, "the Parties should, in implementing measures to achieve their national targets for particulate matter, give priority, to the extent they consider appropriate, to emission reduction measures which also significantly reduce black carbon in order to provide benefits for human health and the environment and to help mitigation of near-term climate change". The parties are encouraged to submit black carbon emission inventories to the UNECE CLRTAP on a voluntary basis, and most of the EU countries have already done this. One of the parties to the UNECE CLRTAP actively working towards ratification of the Gothenburg protocol is Belarus. In 2011 Belarus asked to include its target emission levels in the revised Gothenburg protocol of the Convention.

The current energy strategy in Belarus is aimed at maximizing the share of local energy resources in order to decrease the level of dependency on gas import. Local energy resources are to a large extent represented by peat, brown coal, shale oil, and various wood-based fuels. In the rural areas, houses are most often heated by coal briquettes and firewood. Current knowledge indicates that combustion of solid fuels, especially in the residential sector, is one of the major sources of black carbon emissions. This means that black carbon emissions and impacts in Belarus should not be neglected.

The purpose of the project is to stimulate decision-makers in Belarus to prioritize abatement measures aimed at black carbon in their efforts to reduce emissions of $\mathrm{PM}_{2.5}$, as encouraged in the Gothenburg protocol under the UNECE CLRTAP. To reach this purpose and in order to build up the scientific basis necessary for further policy development, a comprehensive analysis of black carbon emissions, emission reduction potentials and cost-effective abatement measures in Belarus has been conducted. The present report summarizes the results of the analysis.

The report presents two main parts of the conducted analysis: a part focused on the emission inventories, and a part summarizing the results of the integrated assessment modelling. A complete and consistent emission inventory is a good basis for emission projections - but also the inventory results and the underlying data can be very useful as input data for integrated assessment modelling that makes more focus on emission reduction potentials, measures, technical costs and societal benefits. 



\section{2. $P M_{2.5}$ and $B C$ emission inventories and projections in Belarus}

Chapter 2 discusses methods, principles and main results of the first black carbon emission inventory in Belarus. In order to estimate black carbon emissions, the $\mathrm{PM}_{2.5}$ emission inventory has been revised and restructured to be more in line with the EMEP/EEA Guidebook (previously, emissions were estimated by using a sectoral structure as in the GAINS model - an integrated assessment model described in detail in Chapter 4 below). As a result of this revision, several new emission sources have been included, and default Tier I emission factors have been used for a majority of the emission sources. Belarusian black carbon emissions in 2014 have been calculated by applying default $\mathrm{BC} / \mathrm{PM}_{2.5}$ ratios to $\mathrm{PM}_{2.5}$ emissions according to the revised inventory. Further potential improvements in the inventory methodology in Belarus are suggested.

\section{1 $\mathrm{PM}_{2.5}$ emission inventories and projections in Belarus}

Belarus is a party to the UNECE CLRTAP and annually submits emission inventories and accompanying Informative Inventory Report (IIR) to the European Monitoring and Evaluation Programme (EMEP). $\mathrm{PM}_{2.5}$ emissions are reported for the period starting from 2000 and onwards. Belarusian emission inventories submitted to EMEP are based on the principles and methods developed by the Task Force on Emission Inventories and Projections and formulated in the EMEP/EEA Guidebook. In the recent years (prior to Submission 2018), the method based on GAINS modelling, with further aggregation and transformation of the results into the needed format, was used. In underlying calculations for Submission 2018, the EMEP/EEA-method explained in the Guidebook, is applied instead. Major methodological differences, as well as results according to the previous (GAINS-based, as prepared for Submission 2017 and earlier) and improved (EMEP/EEA Guidebook-based, as prepared for Submission 2018) emission inventories are presented and discussed below.

Emission projections are reported by Belarus with a five years interval. The most recent projection was submitted in 2016.

\subsection{1 $P M_{2.5}$ emissions - methodology in the previous inventory}

$\mathrm{PM}_{2.5}$ emission inventories are compiled and verified based on several data sources, including national statistics (on particulate matter emissions, fuel use, industrial production, animal stock, transport, and waste management), the GAINS model database, national emission factors, etc. Methodological details and results presented in the current Chapter are related to the inventory prepared for Submission 2017, in the following entitled the previous inventory. 


\section{Activity data}

Main activity data is statistical data regarding fuel combustion, raw material consumption and industrial production, summarized and reported by the Belarus National Statistical Committee, relevant ministries and other government organisations.

\section{Emission factors}

In the recent inventories, most emission factors used for assessment of $\mathrm{PM}_{2.5}$ have been technology-specific emission factors from the GAINS model database - in particular all emission factors for stationary combustion. A possible disadvantage of this approach might be that unabated emission factors in the model are not updated often enough to include results of the most recently available studies (especially for non-EU countries). The main advantage is a possibility to take into consideration levels of abatement technologies application in the country for each particular time period.

For some sectors (e.g. mobile sources, agriculture) default emission factors from the EMEP/EEA Guidebook were applied. Emission factors used for industrial processes are partly from the EMEP/EEA Guidebook - but some of them are earlier developed national factors. A detailed list of emission factors is presented in Annex 1.

Estimated $\mathrm{PM}_{2.5}$ emissions are further verified by comparison with available national statistics on TSP based on facilities' annual reporting to the National Statistical Committee. Detailed statistical data on TSP emissions in 2014 is given in Annex 2. This verification is also done for the more recent, improved inventory method described in Chapter 2.1.3.

\subsection{2 $P M_{2.5}$ emission trends and sectoral structure in the previous inventory}

\section{Emission trend}

The $\mathrm{PM}_{2.5}$ emission trend is shown in Figure 1. Emissions have been slightly increasing since 2000, mainly due to the growing residential combustion sector, as well as transport and industry (note GNFR ${ }^{1}$ aggregation meaning that industry here comprises both process-related and energy-related emissions). However, there are indications that some recent changes in the implementation of abatement technologies might not have been included in the emission factors applied in the inventory, implying that emissions in recent years might be overestimated.

${ }^{1}$ GNFR = Gridded aggregated NFR sector data; NFR = Nomenclature For Reporting. 
Figure 1: $\mathrm{PM}_{2.5}$ emission trends, by GNFR sector, according to the previous inventory

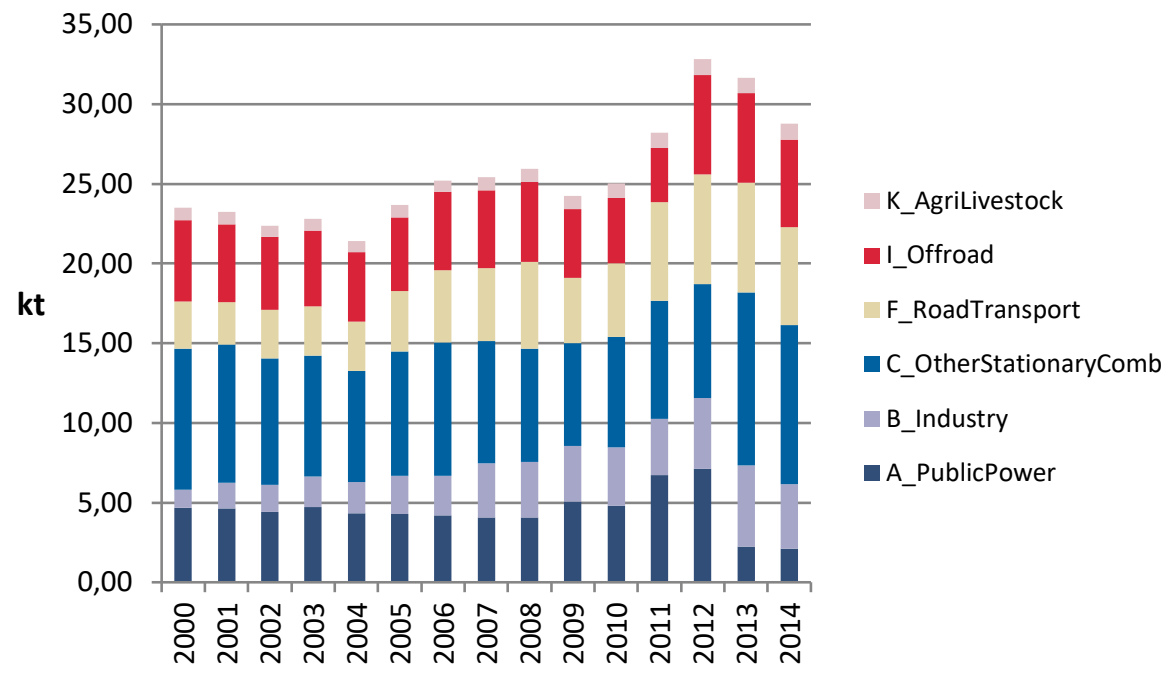

Energy-related $\mathrm{PM}_{2.5}$ emissions in Belarus originate mainly from diesel vehicles and stationary combustion of wood and peat. $\mathrm{PM}_{2.5}$ emissions from combustion of different types of solid fuels are presented in Figure 2. The figure shows an explicit increase of emissions from wood: twice as high in 2014 ( 9.3 ktonnes) than in 2000 (5.0 ktonnes). During the same time period, emissions from coal and peat dropped by $93 \%$ and $50 \%$, respectively. This is most probably the result of the national policy promoting more extensive use of local biofuels (Energy Potential Development Strategy, 2010).

Figure 2: $\mathrm{PM}_{2.5}$ emissions in stationary combustion, by main fuel, according to the previous inventory

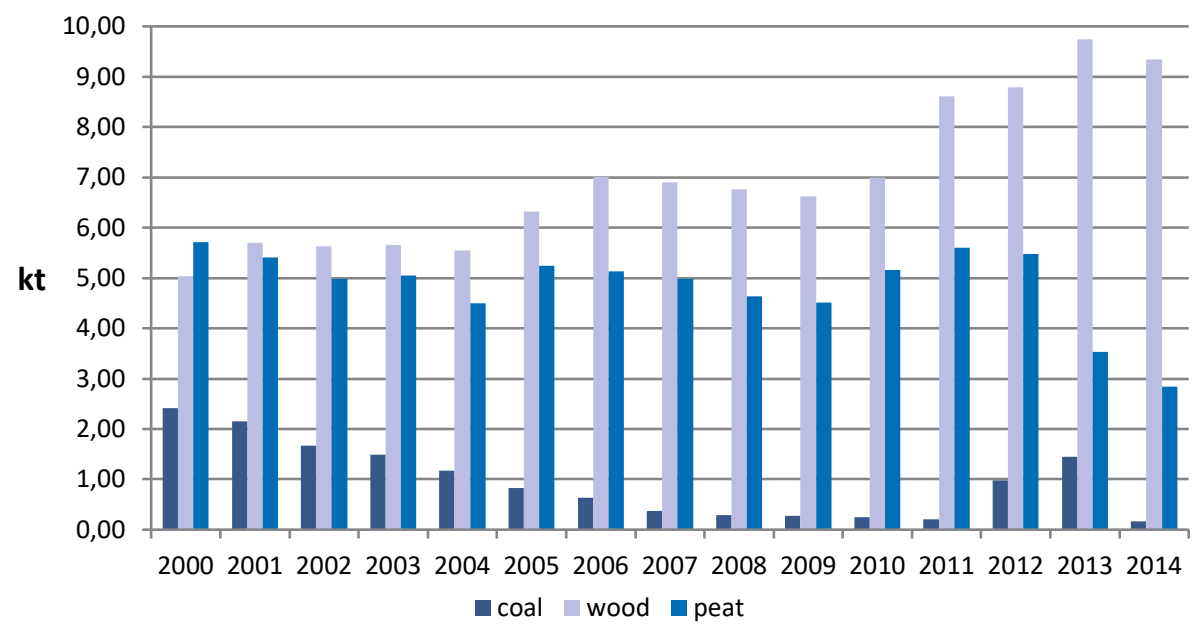

Emission trends by industrial process are displayed in Figure 3. In all sectors, emissions have increased since 2000 - but especially emissions from cement production (204\% since 2000), chemical industries ( $46 \%$ since $\left.2007^{2}\right)$, and glass production ( 0.53 ktonnes, or $>3,000 \%$ since 2000 ). Chemical industries and cement production are two clearly

${ }^{2}$ Emission data for chemical industries are only available from 2007. 
dominating sectors in the industrial process emissions in the recent years, with $37 \%$ of the total emissions in 2014 .

Figure 3: $\mathrm{PM}_{2.5}$ emissions in industry, by industrial process, according to the previous inventory

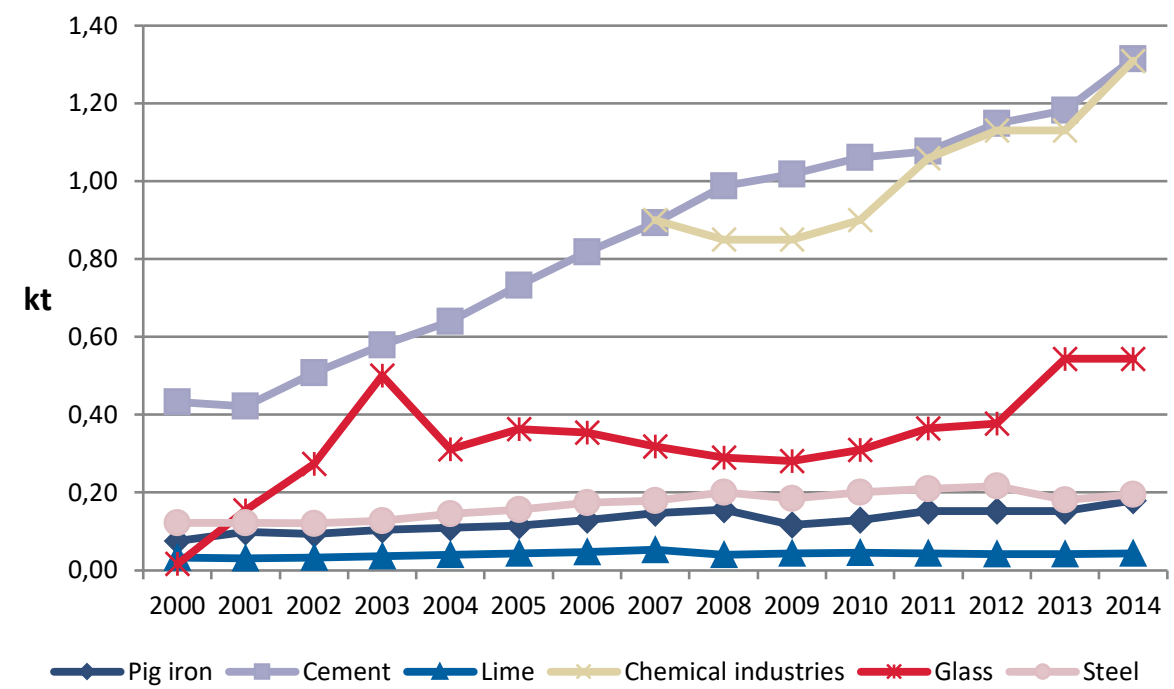

\section{Emission structure in 2014}

The sectoral structure of $\mathrm{PM}_{2.5}$ emissions in 2014 is presented in Figure 4. Most emissions (35\%) originated from residential combustion, followed by road transport (21\%), non-road mobile sources (19\%) and industrial processes (13\%).

Figure 4: $\mathrm{PM}_{2.5}$ emissions in 2014 by sector, according to the previous inventory
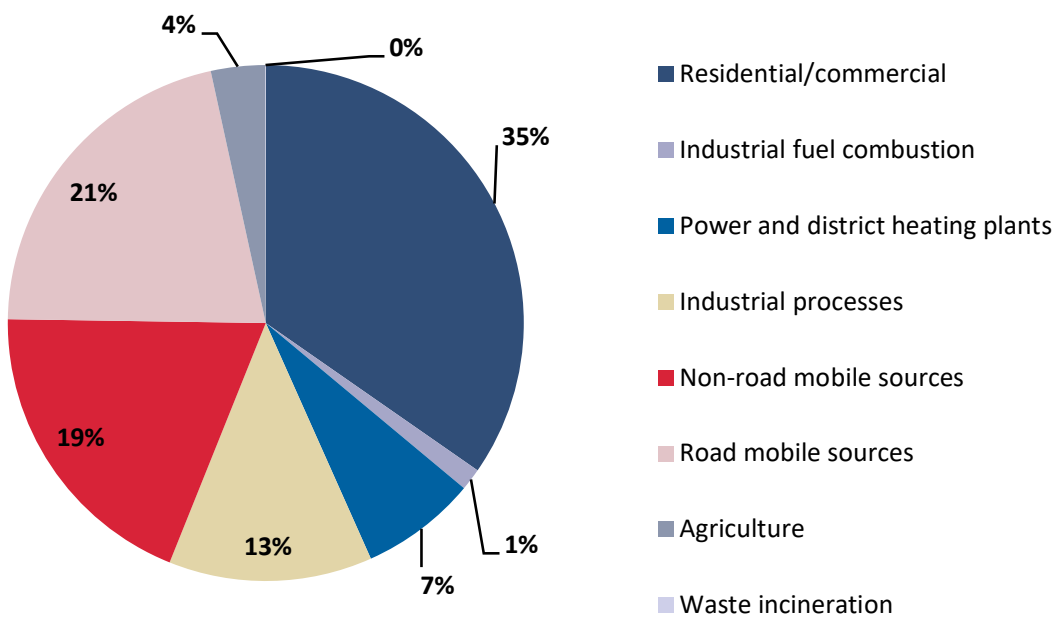

Waste incineration

A more detailed disaggregation of $\mathrm{PM}_{2.5}$ emissions in 2014 by NFR code is presented in Table 1. 


\begin{tabular}{llr}
$1 \mathrm{~A} 1 \mathrm{a}$ & Public electricity and heat production & 2.091 \\
$1 \mathrm{~A} 2 \mathrm{a}$ & Stationary combustion in manufacturing industries and construction & 0.39 \\
$1 \mathrm{~A} 2 \mathrm{fii}$ & Mobile combustion in manufacturing industries and construction & 0.371 \\
$1 \mathrm{~A} 3 \mathrm{bi}$ & Road transport: Passenger cars & 2.773 \\
$1 \mathrm{~A} 3 \mathrm{bii}$ & Road transport: Light duty vehicles & 0.000 \\
$1 \mathrm{~A}$ biii & Road transport: Heavy duty vehicles and buses & 2.975 \\
$1 \mathrm{~A}$ bvi & Road transport: Automobile tyre and brake wear & 0.182 \\
$1 \mathrm{~A} 3 \mathrm{bvii}$ & Road transport: Automobile road abrasion & 0.209 \\
$1 \mathrm{~A} 3 \mathrm{C}$ & Railways & 0.842 \\
$1 \mathrm{~A} 3 \mathrm{~d}$ ii & National navigation (shipping) & 0.004 \\
$1 \mathrm{~A} 4 \mathrm{ai}$ & Commercial/institutional: Stationary & 5.400 \\
$1 \mathrm{~A} 4 \mathrm{bi}$ & Residential: Stationary & 4.577 \\
$1 \mathrm{~A} 4 \mathrm{cii}$ & Agriculture/Forestry/Fishing: Off-road vehicles and other machinery & 4.296 \\
$2 \mathrm{~A} 1$ & Non-metallic minerals production & 2.08 \\
$2 \mathrm{~A} 7 \mathrm{~b}$ & Construction and demolition & 0.048 \\
$2 \mathrm{~B} 5 \mathrm{a}$ & Chemical industry. other & 1.345 \\
$2 \mathrm{C} 1$ & Iron and steel production & 0.196 \\
$4 \mathrm{~B} 1 \mathrm{a}$ & Manure management: dairy cattle & 0.074 \\
$4 \mathrm{~B} 1 \mathrm{~b}$ & Manure management: non-dairy cattle & 0.167 \\
$4 \mathrm{~B} 8$ & Manure management: swine & 0.241 \\
$4 \mathrm{Bga}$ & Manure management: laying hens & 0.493 \\
$4 \mathrm{G}$ & Agriculture. other & 0.000 \\
$6 \mathrm{C}$ & Waste incineration & 0.011 \\
$\mathrm{National}$ & & 28.77 \\
\hline & &
\end{tabular}

\section{Gaps and inconsistencies}

Inconsistencies and gaps in the previous inventory include the following:

- Certain minor emission sources in industries (e.g. road paving with asphalt, asphalt roofing, and paper production) are not included due to lack of activity data and/or emission factors;

- Incomplete estimates for building material industry and fertilizer production;

- For mobile sources, emissions in certain sectors are inconsistent due to methodological changes;

- Incineration of certain waste types, transportation of solid materials and some agricultural processes are not covered by the inventory.

\section{Emission gridding}

Gridded emissions of $\mathrm{PM}_{2.5}$ are not compiled. Gridded emissions of $\mathrm{PM}_{10}$ emissions (assumed to be the same as TSP) in Belarus are compiled every 5 years. The spatial distribution of emissions in the country for the years 2005 and 2010 (at $50 \mathrm{~km}$ grid) is presented in Figure 5. Emission "hot spots" on the map are co-located with the largest cities with extensive traffic and a large number of industrial enterprises. The grid cell with the highest emissions contains the country capital Minsk - a city with $\sim 2$ million people and $\sim 3,700$ industrial enterprises) in 2015 (National Statistical Committee 2016). 


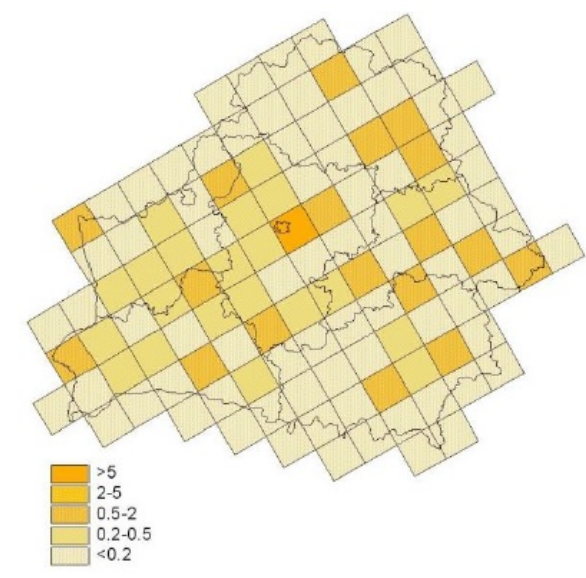

2005

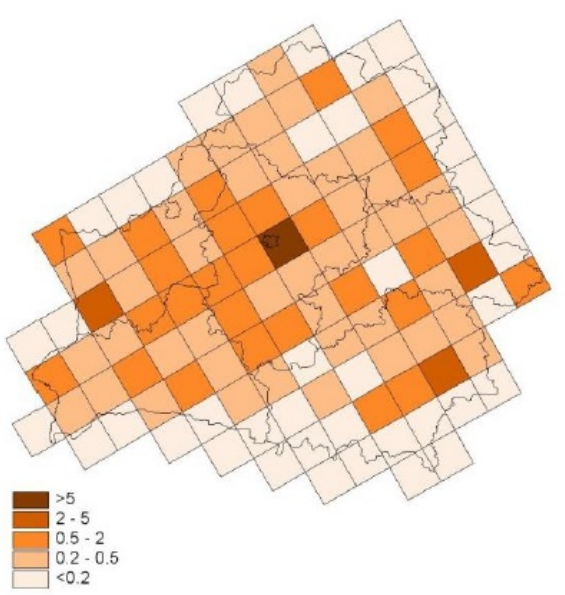

2010

$\mathrm{PM}_{2.5}$ emission projections

The first $\mathrm{PM}_{2.5}$ emission projection in Belarus was produced in 2010-2011 and covered the period until 2020. The most recent emission projection was submitted in 2016 for the years up to 2030. The methodology used to produce projections involves GAINS modelling with the results further transposed into the required reporting format. Activity data for future years are estimated based on available sectoral and national development strategies. According to the projection submitted in 2016, $\mathrm{PM}_{2.5}$ emissions in Belarus will amount to 37.1 ktonnes in 2030 if no further measures or instruments, except for those already agreed in the legislation, are taken into account.

\subsection{3 $P M_{2.5}$-improvements in the emission inventory}

In the emission inventory prepared for Submission 2018, the EMEP/EEA Guidebookbased method is used instead of the previously applied GAINS-based method. The two main differences between these methods include:

- Re-aggregation of the sectoral structure to be in line with the one applied in the EMEP/EEA Guidebook - this resulted in the inclusion of some new emission sources in the inventory, e.g. asphalt roofing and paper production;

- Changing emission factors from GAINS-based to default Tier l emission factors presented in the EMEP/EEA Guidebook has also resulted in re-allocations of certain emission sources. In particular, production of non-metallic minerals has been moved to the industrial combustion sector in order to be able to apply the default emission factors.

The total resulting $\mathrm{PM}_{2.5}$ emissions in 2014 in the improved inventory account to 33.38 ktonnes - an increase by $16 \%$ compared to the previous inventory. The sectoral structure of emissions according to the improved inventory is presented in Figure 2. The most visible change, compared to the structure in the previous inventory (Figure 4 ), is 
the substantially increased share of residential combustion (mainly due to the emission factor changes) and industrial fuel combustion (due to the re-allocation from industrial processes). The total share of emissions from industrial processes has not been changed a lot-the re-allocation of the non-metallic mineral production to the industrial combustion sector is compensated by the inclusion of new emission sources in the inventory.

Figure 6: $\mathrm{PM}_{2.5}$ emissions in 2014 by sector, according to the improved inventory

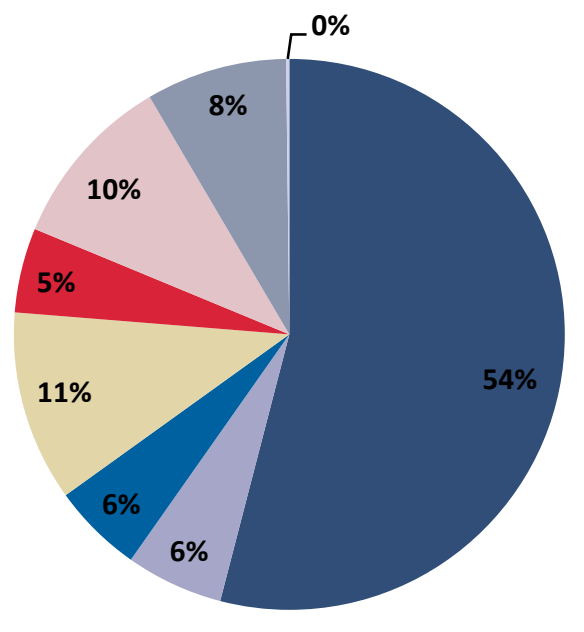

\author{
- Residential/commercial \\ - Industrial fuel combustion \\ - Power and district heating plants \\ Industrial processes \\ non-road mobile sources \\ Road mobile sources \\ Agriculture \\ Waste incineration
}

A more detailed disaggregation of $\mathrm{PM}_{2.5}$ emissions in 2014 by NFR code in the improved inventory is presented in Table 2.

Table 2: $\mathrm{PM}_{2.5}$ emissions in Belarus in 2014 by NFR, according to the improved inventory

Public electricity and heat production

Stationary combustion in manufacturing industries and construction

1.908

Mobile combustion in manufacturing industries and construction

Road transport: Passenger cars

$1 \mathrm{~A} 3 \mathrm{bi}$

Road transport: Light duty vehicles

0.722

1 A3bii

Road transport: Heavy duty vehicles and buses

0.000

1Azbvi

Road transport: Automobile tyre and brake wear

1.658

$1 \mathrm{~A} 3$ bvii

Road transport: Automobile road abrasion

0.674

Railways

0.381

${ }_{1} \mathrm{~A} 3 \mathrm{C}$

National navigation (shipping)

0.281

$1 \mathrm{~A}_{4}$ ai

Commercial/institutional: Stationary

0.005

Commercial/institutional: Stationary

4.115

${ }_{1} \mathrm{~A}_{4} \mathrm{bi}$

${ }_{1} \mathrm{~A}_{4}$ cii

Stationary

13.925

Agriculture/Forestry/Fishing: Off-road vehicles and other machinery

1.239

Construction and demolition

0.043

$2 \mathrm{~B} 5$

$2 D, 2 G, 2 H$

Chemical industry. other

1.057

Other industrial processes and product use (Road paving with asphalt, paper $\quad 0.364$

$2 \mathrm{C}_{1}$

production, asphalt roofing, other product use)

$4 \mathrm{~B} 1 \mathrm{a}$

Iron and steel production

2.274

Manure management: dairy cattle

0.627

$\begin{array}{ll}\text { Manure management: non-dairy cattle } & 0.507\end{array}$

$4 \mathrm{~B} 1 \mathrm{~b}$

$4 B 8$

Manure management: swine

0.186

Manure management: laying hens

1.080

$4 \mathrm{Bga}$

Agriculture. other

0.365

$6 \mathrm{C}$

Waste incineration

0.062 
As for the fuel structure of energy-related $\mathrm{PM}_{2.5}$ emissions in 2014 - it has changed as well in the new method, see Figure 7. The numbers in the improved inventory indicate a much higher contribution to the emissions from wood and natural gas - and a much lower contribution from diesel, compared to the previous inventory. This is due to the change of emission factors used.

Figure 7: Fuel structure of energy-related $\mathrm{PM}_{2.5}$ emissions in 2014

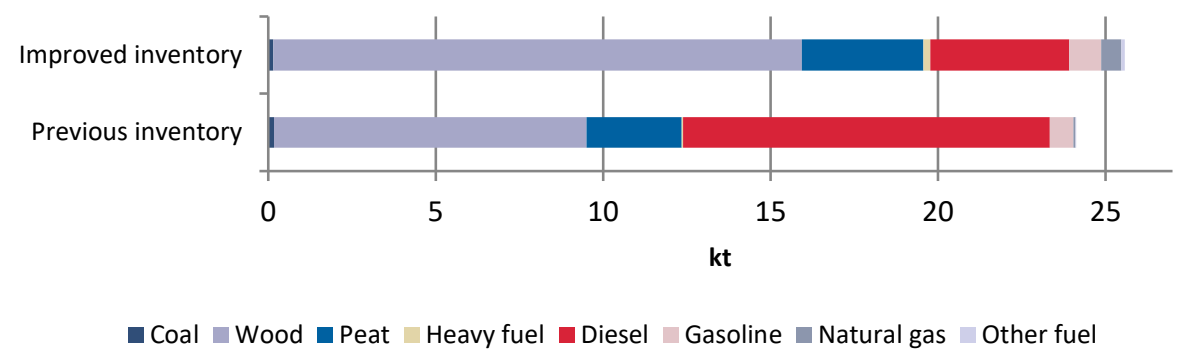

The main differences in the methodologies and the results of the improved (EMEP/EEA Guidebook-based) inventory compared to the previous (GAINS-based) inventories can be summarized as:

- The EMEP/EEA Guidebook-based sectoral structure and default Tier I emission factors are applied;

- More sectors are included: aviation, asphalt roofing, road paving with asphalt, pulp and paper production, cremation, incineration of certain types of waste;

- Higher emissions from agriculture and waste sectors;

- Much higher emissions from the residential combustion sector and industrial combustion;

- Substantially higher emissions from wood (residential combustion) and much less from diesel (mobile sources).

The improved $\mathrm{PM}_{2.5}$ emission inventory is considered to be more complete, more comparable to inventories in other countries, and much more suitable for using as a basis in the compilation of the country's first BC emission inventory.

\subsection{Black carbon emission inventory in Belarus}

This Chapter presents the methodology and the results of the first national black carbon emission inventory in Belarus. The method, like in many other countries, is based on the improved $\mathrm{PM}_{2.5}$ emission inventory and $B C / \mathrm{PM}_{2.5}$ ratios provided in the EMEP/EEA Guidebook. Although national black carbon emissions in Belarus have been estimated for the first time, statistical data on emissions from certain industrial sources has been available in Belarus since the Soviet era. In the statistics, the term soot is used instead of black carbon. Available statistics thus can be considered as a proxy for verification of black carbon emission estimates from certain sources. In this report, we will use the term soot 
when talking about available statistics for particular emission sources, and black carbon when presenting the results of the first national emission inventory.

\subsubsection{Statistical data on soot emissions}

Soot is one of the parameters included in the reporting form 1-OC (air) that over 2,000 industrial facilities in Belarus ${ }^{3}$ are obliged to submit annually to the Ministry of Natural Resources and Environment via the Belarusian Research Center Ecology. Since there is no approved instrumental measurement standard for soot/BC in the country, facilities estimate their emissions by calculation methods, using a range of national guidelines updated in 2006-2011. The available methodological base for soot emission calculations is summarized in Annex 3.

The Ministry of Natural Resources and Environment aggregates facilities' emission data before submitting it to the National Statistical Committee of the Republic of Belarus (Belstat) 4 responsible for publishing. Available historical data for stationary emission sources (Figure 8) indicate a downward trend: emissions have decreased by $68 \%$ between 2001 and 2013 - from 2,615 tonnes to 828 tonnes.

Figure 8: Statistical data on soot emissions from stationary sources in Belarus, tonnes

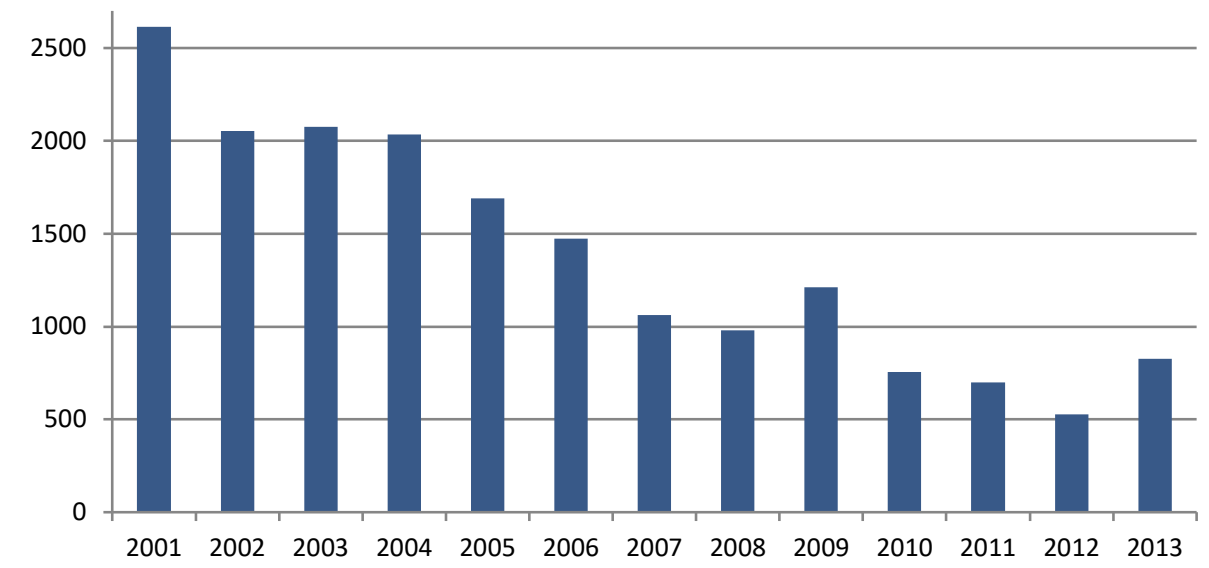

Source: Belstat.

Table 3 presents soot emissions from stationary sources in 2013, as published by the Statistical Committee. The total annual soot emissions in 2013, according to this statistics, amount to $~ 0.8$ ktonnes. The main source of soot emissions is manufacturing industry $-426.1 \mathrm{t}$ ( $51 \%$ of total emissions). There are also significant contributions from the source categories fossil fuels extraction (21\%) and public electricity and heating (18.5\%). The shares from other sources do not exceed $5 \%$. These soot emissions are only part of the actual total national soot emissions since some of the important sources (such as for instance all diesel-fuelled vehicles and residential fuel combustion) are excluded from the statistics.

${ }^{3}$ Facilities emitting over 25 tonnes air pollutants per year.

$4 \mathrm{http}: / /$ www. belstat.gov.by/en/ 
Manufacturing industry

426.13

Including

-Production of coke, petroleum products and nuclear materials $\quad 304.11$

-Metallurgical production $\quad 40.68$

$\begin{array}{ll}\text {-Production of vehicles } & 22.08 \\ \text {-Fod and } & \end{array}$

-Food and drink industry (including tobacco products)

-Chemical industry $\quad 6.88$

-Production of machinery and equipment $\quad 5.09$

\begin{tabular}{ll}
-Textile industries & 4.44 \\
\hline & Producton
\end{tabular}

Production of rubber and plastics 3.48

Public electricity and heating $\quad 153.28$

Fossil fuel extraction $\quad 175.67$

Agriculture and forestry 37.12

Transport and communication enterprises $\quad 30.84$

Other sources $\quad 4.92$

\begin{tabular}{lr} 
Total & 827.96 \\
\hline
\end{tabular}

Spatial distribution of reported soot emissions is not even across the country. The main part of emissions come from the Vitebsk region (see Figure 9) - more than 200 tonnes, or $25 \%$ of the country total. The Vitebsk region is known for the largest oil refinery complex in Belarus, which is the main reason for high emission levels compared to the rest of the country. Relative inputs from other regions are much lower, less than 100 tonnes per region.

Figure 9: Spatial distribution of reported soot emissions in Belarus in 2013, tonnes/region

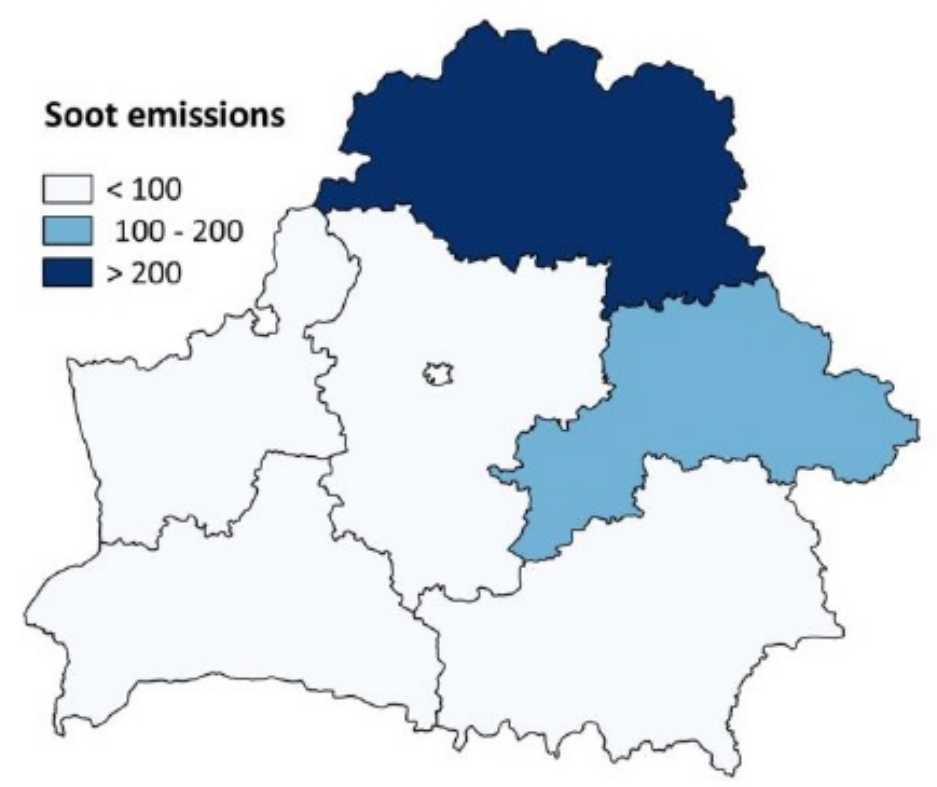

Source: Belstat. 
Methodology

The first Belarusian $B C$ emission inventory was compiled by applying $B C / P M_{2.5}$ ratios available in the EMEP/EEA Guidebook (Table 4 and 5). The $\mathrm{PM}_{2.5}$ emissions used in the calculations were those compiled with the improved emission inventory methodology (as described in Chapter 2.1.3).

Table 4: $\mathrm{BC} / \mathrm{PM}_{2.5}$ as specified in the EMEP/EEA Guidebook - example for stationary combustion, \%

\begin{tabular}{|c|c|c|c|c|c|c|}
\hline NFR & Wood & Coal & Peat & Natural gas & $\begin{array}{l}\text { Other } \\
\text { gaseous fuels }\end{array}$ & Liquid fuels \\
\hline $1 \mathrm{~A}_{1} \mathrm{a}$ & 3.3 & 2.2 & - & 2.5 & 2.5 & 5.6 \\
\hline $1 A_{1} b$ & - & - & - & - & - & 5.6 \\
\hline 1A4ai & - & 6.4 & 6.4 & 2.5 & 4 & 56 \\
\hline $1 \mathrm{~A}_{4} \mathrm{bi}$ & 10 & 6.4 & 6.4 & 5.4 & 5.4 & - \\
\hline${ }_{1} A_{2}$ & 28 & 6.4 & 6.4 & 4 & 4 & 56 \\
\hline
\end{tabular}

Table 5: BC/PM ${ }_{2.5}$ as specified in the EMEP/EEA Guidebook - example for industrial processes, \%

\begin{tabular}{llr} 
NFR & Category & $\%$ of $\mathrm{PM}_{2.5}$ \\
& & \\
$1 \mathrm{~A}_{2} f$ & Lime production & 0.46 \\
$1 \mathrm{~A}_{2} \mathrm{f}$ & Glass production & 0.062 \\
$2 \mathrm{C}_{1}$ & Steel production & 0.36 \\
$2 \mathrm{~B} 10 \mathrm{a}$ & Fertilizer production & 1.8 \\
$2 \mathrm{H} 1$ & Paper production & 2.6 \\
\hline
\end{tabular}

An exception was made for fugitive emission from the fuel production sector, where the accuracy of statistics is considered to be high enough to be used directly in the black carbon emission inventory. Fugitive emissions in this sector are calculated as a difference between the total reported statistical soot emissions at fuel production facilities and the EEA/EMEP Guidebook-based estimate of emissions from fuel combustion at the same facilities.

Results

The resulting black carbon emissions in 2014 are presented by sector and fuel in Figure 10, together with $\mathrm{PM}_{2.5}$ emissions according to the improved inventory. Total national black carbon emissions in 2014 are estimated at 3.87 ktonnes (12\% of the total national $\mathrm{PM}_{2.5}$ emissions in 2014). About 1.35 ktonnes (35\%) originates from residential combustion - which can be compared to 0.8 ktonnes from stationary sources reported in the national soot statistics (see above). Road and non-road mobile sources are the second and the third largest contributors, with 1.00 ktonnes (26\%) and 0.97 ktonnes (25\%) black carbon emissions, respectively. Contribution from other sources, unlike for $\mathrm{PM}_{2.51}$ is insignificant due to much lower $\mathrm{BC} / \mathrm{PM}_{2.5}$ fractions. 

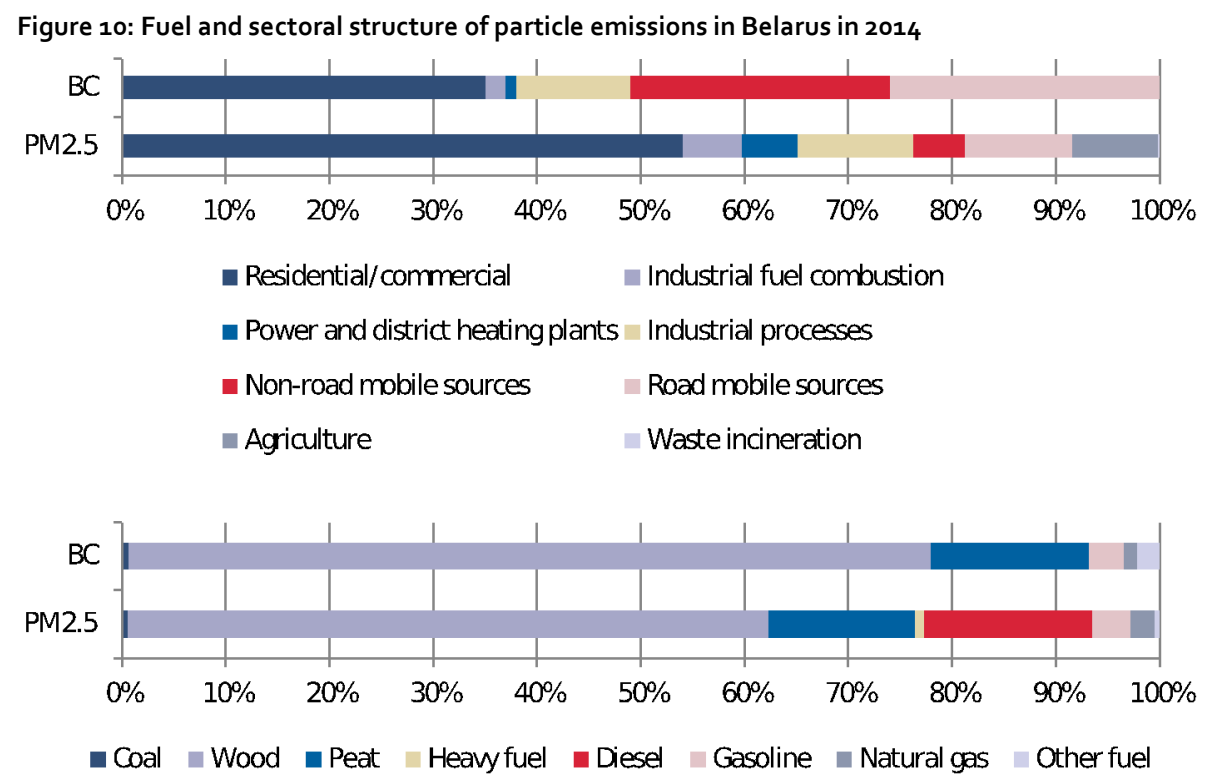

The fuel structure of black carbon emissions is dominated by diesel (45\%) and wood $(40 \%)$. Wood is the main contributing fuel for energy-related stationary sources ( $>70 \%$ of the total energy-related emissions from stationary sources), while emissions from mobile sources are dominated by diesel ( $97 \%$ of the total emissions from vehicles).

Emissions from industrial processes are rather equally split between four major categories - lime (28\%), NPK fertilizers (24\%), paper (22\%) and steel (15\%), as shown in Figure 11.

Figure 11: Black carbon emissions from industrial processes in Belarus in 2014

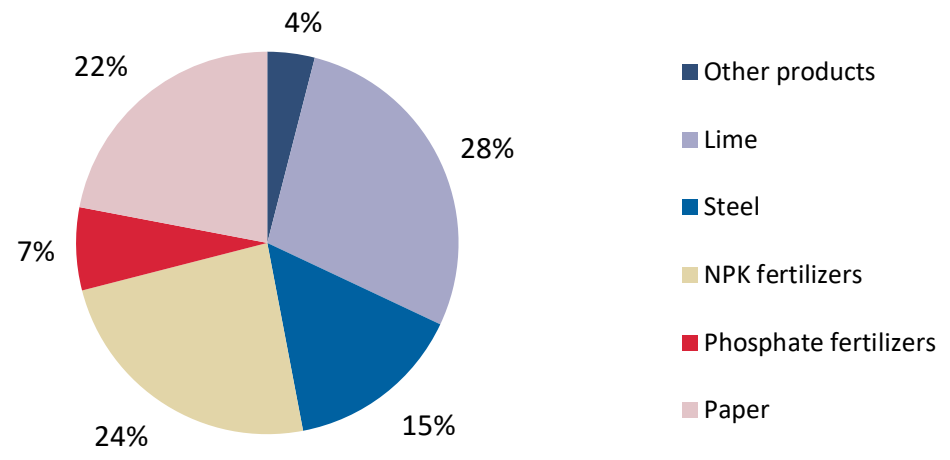

\section{3 $\mathrm{PM}_{2.5}$ and $\mathrm{BC}$ emission inventories and projections in Belarus - further improvement suggestions}

Although the $P M_{2.5}$ emission inventory has been revised for Submission 2018 and has become more complete, there are still areas where further improvements can be made. These could include considering the more detailed Tier II methodologies or developing Tier III (national) emissions factors to be used instead of Tier I defaults where possible (in particular, for the main emission source categories). The choices of default Tier II 
emission factors, as well as the development of Tier III emission factors, often depend on abatement status. Further improvements in the inventory can thus be done by taking into consideration changes of the application rates of abatement technologies over time. This requires regular collection of real-life data on production and abatement status from the industries.

$\mathrm{PM}_{2.5}$ emissions from the following sources are not estimated in the improved inventory:

- Fugitive emissions from solid fuel production/transformation;

- Fossil fuel extraction;

- Handling and transportation of products and fuels;

- Incineration of certain types of waste;

- Waste handling other than incineration;

- Fires and other sources of open burning.

The main reasons for these "gaps" are either the absence of default emission factors in the EMEP/EEA Guidebook or difficulties in obtaining activity data on the desired level of aggregation. However, contributions from these sources to the total $\mathrm{PM}_{2.5}$ emissions (and BC emissions) are considered insignificant.

The main potential for improvements of the compiled black carbon inventory is extending it to cover the time period from the year 2000 in order to reflect the historical trend of emissions - and in order to produce emission projections. Also, there is a need for harmonization of definitions in the national standards (soot, black carbon, elemental carbon etc.). Another improvement would be to analyse the potential use of soot emission statistics (e.g. for stationary diesel generators and railroad transport) in the national black carbon inventory.

For both $\mathrm{PM}_{2.5}$ and $\mathrm{BC}$, there is a need for development of measurement standards that can be applied along with, or instead of, calculation methods widely used by industrial facilities and other institutions to estimate particle emissions. Requirements for statistical reporting can be improved as well, to include more facilities and emission sources in the national statistics. 



\section{3. $P M_{2.5}$ and $B C$ emission inventories in the Nordic countries}

Chapter 3 presents historical and projected $\mathrm{PM}_{2.5}$ and $\mathrm{BC}$ emissions in Denmark, Finland and Sweden (hereinafter referred to as "the Nordic countries"), and discusses differences and similarities in the emission inventory methods and results in the three Nordic countries and Belarus. The two major emission sources of BC emissions in all four countries are residential combustion and use of diesel fuel in the transport sector. According to the available projections, these sources seem to remain significant contributors to the total national emissions also in the future.

\subsection{Black carbon emission inventories and projections in the Nordic countries - methodological aspects}

The Nordic countries produced their first officially reported black carbon emission inventories in 2012-2015. In Finland, black carbon emissions have been modelled since 2005; the first official reporting was however done in 2012. Black carbon emissions cover the time period starting from the year 2000 (data for earlier years are considered to be too uncertain), while $\mathrm{PM}_{2.5}$ emissions usually are reported for the period starting from 1990 .

In Sweden and Denmark, black carbon emissions are estimated by applying $\mathrm{BC}$ / $\mathrm{PM}_{2.5}$ ratios from the Guidebook to $\mathrm{PM}_{2.5}$ emissions. Emissions of $\mathrm{PM}_{2.5}$ are estimated by applying $\mathrm{PM}_{2.5} / \mathrm{TSP}$ ratios, which are most often sector-specific expert estimates or adopted from the EMEP/EEA Guidebook. TSP (and sometimes also $\mathrm{PM}_{10}$ ) emissions are specified by facilities in annual environmental reports. Finland uses national emission factors for certain emission sources - such as residential combustion.

Main efforts to improve the inventories are made in the key emission sectors - such as residential combustion and diesel-fuelled vehicles (emissions by sectors are presented in Chapter 3.2 below). To make emissions from the residential sector more complete and accurate, the countries conduct surveys aimed at collecting more detailed data on combustion. Surveys include questions on both technical aspects (types and age of used installations) and behavioural patterns (load size, ignition method, using bad quality fuel) - all these parameters affect emission factors (Kindbom et al. 2017). A methodological challenge that the Nordic countries struggle with is harmonizing available activity data (most often provided by energy agencies on a rather coarse level of aggregation) with more detailed technology-specific emission factors. Finland has the most developed inventory of particle emissions from residential combustion, which is based on modelling in the national model FRES 5 and also used for integrated assessment modelling. The model operates with several types of appliances

${ }^{5}$ FRES $=$ Finnish Regional Emission Scenario model. 
and wood types and allows for considering so-called "bad" combustion with higher emission factor than "regular" combustion.

Emissions from diesel-fuelled vehicles are estimated using models. In Sweden, the HBEFA $^{6}$ model is used for road transport and a nationally developed model for nonroad transport. Finland is using the national transport emission model LIPASTO that in turn "collects" stock and traffic data flows from several sub-sectoral models (road, railway, water transport, etc.). In Denmark, the COPERT7 methodology is used.

For $\mathrm{BC}$ projections, either national (sectoral) models are used, or projections can be integrated into the same methods that are used to calculate historical emissions (the latter is used in Sweden).

Uncertainties for BC emissions are not yet estimated by all the Nordic countries. In the Finnish emission inventory, the total black carbon emission uncertainty in 2014 was estimated at $-44 \%$ to $58 \%$, using Monte-Carlo simulation. In can be noted that residential combustion is not only one of the largest emission sources - it also seems to be one of the most uncertain ones.

Despite the long-term experience in compilation of emission inventories in the Nordic countries, there is always potential for improvements. Some of the emission sources are not included due to the lack of emission factors, BC/PM 2.5 ratios and/or activity data - examples are road abrasion in Sweden, aviation and fugitive emissions from fuels in Finland, emissions from product use (fireworks, tobacco smoking) in both Sweden and Denmark. In some sectors (such as chemical industries in Sweden) there are data gaps and inconsistencies that require further efforts on data collection and methodology development.

Main emission sources of particles are rather similar in the Nordic countries and in Belarus - residential combustion is a key source in all countries. The main methodological challenge in Belarus is making more accurate estimates of activity data, normally extracted from national fuels statistics where residential combustion is not even separated from other combustion. Data on types and age of appliances are lacking as well. Within the project, several seminars have been held to share the expertise on methodological aspects of emission inventories and integrated assessment modelling with Belarus as well as within the three involved Nordic countries. The following ways forward for improving the residential combustion sector inventory have been identified:

- Further development of survey methods, effective processing of the results and their integration in the inventories;

- Development of methods and standards for measurement of particle emissions for further development of (national) emission factors;

- Development of cooperation with organisations focusing on fuel research, branch associations for appliance producers and professional organisations for chimneysweeps;

- Harmonization of emission inventories and projections with integrated assessment modelling.

${ }^{6}$ HBEFA $=$ HandBook Emission FActors for road transport.

7 http://www.emisia.com/utilities/copert/ 


\section{2 $\quad \mathrm{PM}_{2.5}$ and $\mathrm{BC}$ emission inventories and projections in the Nordic countries - summary of the recent estimates}

Historical trends and projections of black carbon and $\mathrm{PM}_{2.5}$ emissions in Denmark, Finland and Sweden are displayed in Figure 12.

Figure 12: $\mathrm{PM}_{2.5}$ (left) and $\mathrm{BC}$ (right) emissions and projections in the Nordic countries

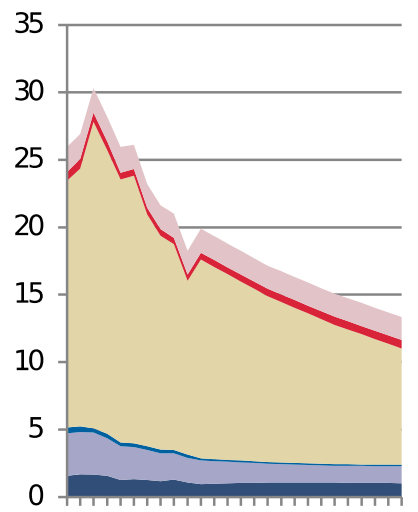

200520102015202020252030

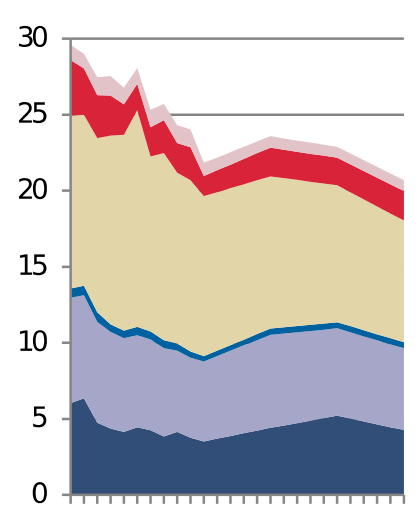

200520102015202020252030

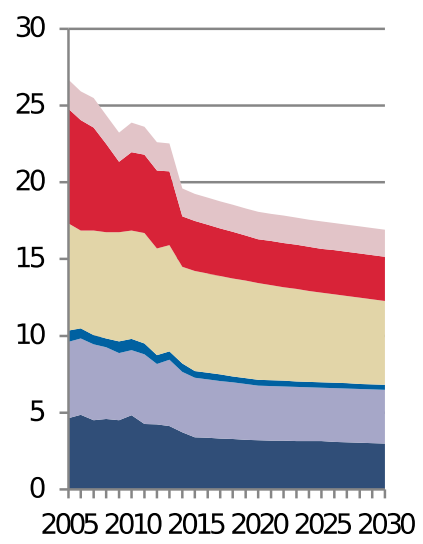

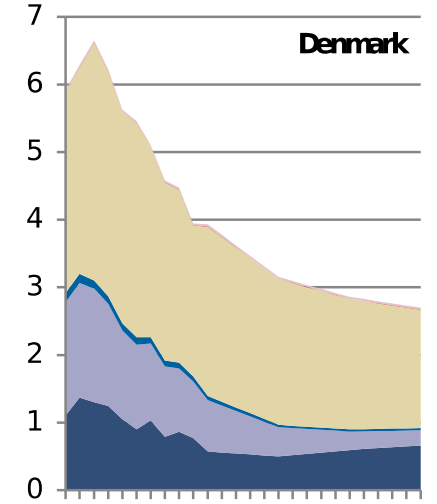

200520102015202020252030
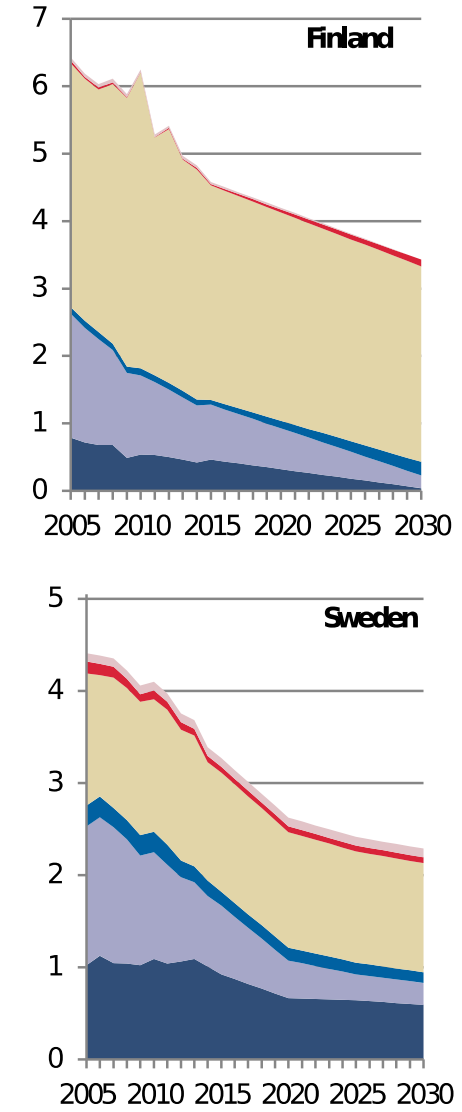

\author{
Agriculture, waste, \\ product use \\ - Industrial Processes \\ Residential \\ combustion (tagr \\ forestry, fishing)) \\ - Off-road transport \\ Road Transport \\ Fuel combustion and
} fugitives

\section{Agriculture, waste, product use \\ - Industrial Processes \\ Residential combustion (tagr. forestry, fishing)) - Off-road transport \\ - Road Transport \\ - Fuel combustion and fugitives \\ Agriculture, waste, product use \\ n Industrial Processes \\ Residential \\ combustion (tagr, forestry, fishing)) \\ n Off-road transport \\ Road Transport \\ - Fuel combustion and fugitives}

Source: Kindbom et al. 2018. 
In all three countries, both $\mathrm{PM}_{2.5}$ and $\mathrm{BC}$ emissions show descending trends - from 2530 ktonnes in 2005 to $13-22$ ktonnes in 2030. For historical emissions of $P M_{2.5}$, residential combustion and road transport have been the key emission sources from 2005 and until now (one other significant source in Sweden seems to be industrial processes). This will also be valid for the year 2030, according to the recent projections (Kindbom et al. 2018).

For $B C$, national totals in 2005 amount to 4-7 ktonnes while the projected emissions in 2030 are 2-4 ktonnes - thus the emissions are expected to decrease by around $50 \%$ in each of the three countries, mostly due to reductions from road traffic and from the energy sector. At the same time, emissions from residential combustion will remain relatively constant, implying much higher share of this sector in the national totals in 2030.

Emissions of $\mathrm{PM}_{2.5}$ and $\mathrm{BC}$ in the Nordic countries in 2014 are estimated at $18-22$ ktonnes and 3.5-4.5 ktonnes, respectively. Emissions in Belarus for the same year are estimated at 33.4 ktonnes $\mathrm{PM}_{2.5}$ and 3.9 ktonnes $\mathrm{BC}$ - this corresponds to the level of particle emissions in the Nordic countries in 2005. Belarus is behind in the emission reductions due to different regulations and a more industrial-focused structure of country economics in general. National totals for black carbon emissions in Belarus are, however, rather close to those in the Nordic countries. The sectoral structure of emissions is similar as well - according to the emission inventory, dominating sectors are residential combustion, transport and industrial processes.

Emission projections are a starting point for the assessment of further emission reduction potential; however, it is not enough to identify effective reduction measures in the key emitting sectors. For this type of analysis, we use integrated assessment modelling, as presented in the following chapters. 


\section{4. $\mathrm{PM}_{2.5}$ and $\mathrm{BC}$ : Integrated assessment for Belarus}

Detailed emission inventories and emission projections provide decision-makers and scientists with a reliable picture of past emission trends and the most probable future development. Most often, emission projections take into consideration only already implemented (or at least agreed) policy instruments and measures. From the policy perspective, however, this is only a starting point, a necessary basis for further analysis. To decide on cost-effective policy instruments in the future, decision-makers need to know more-how high emission reduction potentials are, what emitting sources are the most relevant for abatement measures, what measures are available, how much would they cost, and what benefits to environment and people's health would they bring in the considered and surrounding countries. In the present study, an integrated assessment investigating all these questions has been conducted for both Belarus and the Nordic countries - the results are displayed in this Chapter.

To estimate future emissions and emission reduction potentials, to identify costeffective abatement measures and to calculate the associated costs, we use the GAINS model. GAINS ${ }^{8}$ is an integrated assessment model, an extension of the RAINS ${ }^{9}$ model originally developed within the UNECE CLRTAP to identify and explore cost-effective emission control strategies for air pollutants (Amann et al. 2011b). Later, the possibility to analyse greenhouse gas emissions and measures was included. The model is developed and maintained by the International Institute for Applied System Analysis (IIASA) and is widely used as a unified tool for scientific analysis of economic and environmental consequences of air pollution abatement strategies and climate mitigation measures. With its broad database on abatement measures and in-built emission dispersion parameters, GAINS enables analysis of emissions, costs and health and environmental effects for relevant policy scenarios. Furthermore, a costoptimization mode is available for determining the most cost-effective solutions to reach suggested health or/and environmental targets.

\subsection{Baseline emissions, MFR and emission reduction potentials}

In order to estimate emission reduction potentials, two scenarios need to be analysed:

- Baseline scenario - the one implying efficient enforcement of committed legislation only, with no further action assumed;

\footnotetext{
${ }^{8}$ GAINS = Greenhouse Gas - Air Pollution Interactions and Synergies.
}

${ }^{9}$ RAINS = Regional Air Pollution Information and Simulation. 
- Maximum Feasible Reduction (MFR) - scenario implying maximum possible implementation of the most efficient emission reduction measures available on the market.

The difference in emissions between these two scenarios constitutes emission reduction potential.

\subsubsection{Baseline scenario}

Baseline scenarios in GAINS are updated by IIASA on a regular basis. In our analysis for Belarus, however, we use the baseline scenario developed by the national experts Eclipsev5a_Bel. Though it is based on the most recent publically available baseline developed by IIASA - ECLIPSE_V5a_CLE_base (Stohl et al. 2015) - for a range of sectors national estimates of energy consumption and production numbers are quite different from IIASA's numbers. The national scenario, for instance, assumes rather substantial use of peat in the country's fuel structure (up to $20 \%$ of the total solid fuel use) while in the ECLIPSE_V5a_CLE_base peat consumption is not noticeable at all. Further in this report, by "baseline" for Belarus we mean the national scenario (Eclipsev5a_Bel).

It's worth noting that IIASA's baseline scenarios are continuously developed and improved so that the two consequent baselines may be very different as well. The most recent baseline prior to ECLIPSE_V5a_CLE_base is WPE_2014_CLE from TSAP scenario group (a group of scenarios developed for the European Clean Air and Policy Package presented in 2013 and described in Amann et al. 2015). Those two scenarios show different results for particle emissions in Belarus in 2030 - see Table 6. Emission differences origin in the different assumptions for activity data - in particular, in the industrial production numbers. WPE_2014_CLE assumes much higher numbers for production of fertilizers and steel in 2030 than ECLIPSE_V5a_CLE_base does (see Figure 13), which results in twice as high $\mathrm{PM}_{2.5}$ emissions from industrial processes in the ECLIPSE_V5a_CLE_base ( 32 ktonnes) compared to WPE_2014_CLE ( 15 ktonnes). In other sectors, there is virtually no difference in emissions. $\mathrm{BC}$ emissions are similar since they are not that much affected by assumptions for these two industrial processes.

Table 6: $\mathrm{PM}_{2.5}$ and $\mathrm{BC}$ emissions in Belarus, according to different estimates, ktonnes

\begin{tabular}{|c|c|c|c|c|}
\hline \multirow[t]{2}{*}{ Source /scenario } & \multicolumn{2}{|c|}{$\mathrm{PM}_{2.5}$} & \multicolumn{2}{|c|}{ Black carbon } \\
\hline & $2014 / 15$ & 2030 & $2014 / 15$ & 2030 \\
\hline Emission inventory, previous & 28.8 & - & - & - \\
\hline Emission inventory, improved & 33.4 & - & 3.87 & - \\
\hline National emission projection & - & 37.1 & - & - \\
\hline WPE_2014_CLE (Amann et al. 2015) & 51.5 & $54 \cdot 5$ & 6.8 & $7 \cdot 4$ \\
\hline ECLIPSE_V ${ }_{5}$ a_CLE_base & 58.0 & 70.9 & 6.9 & $7 \cdot 5$ \\
\hline Eclipsev5a_Bel & 53.7 & 52.0 & 4.6 & 3.6 \\
\hline
\end{tabular}


Figure 13: Discrepancies in activity data for industrial processes in Belarus underlying different baseline scenarios

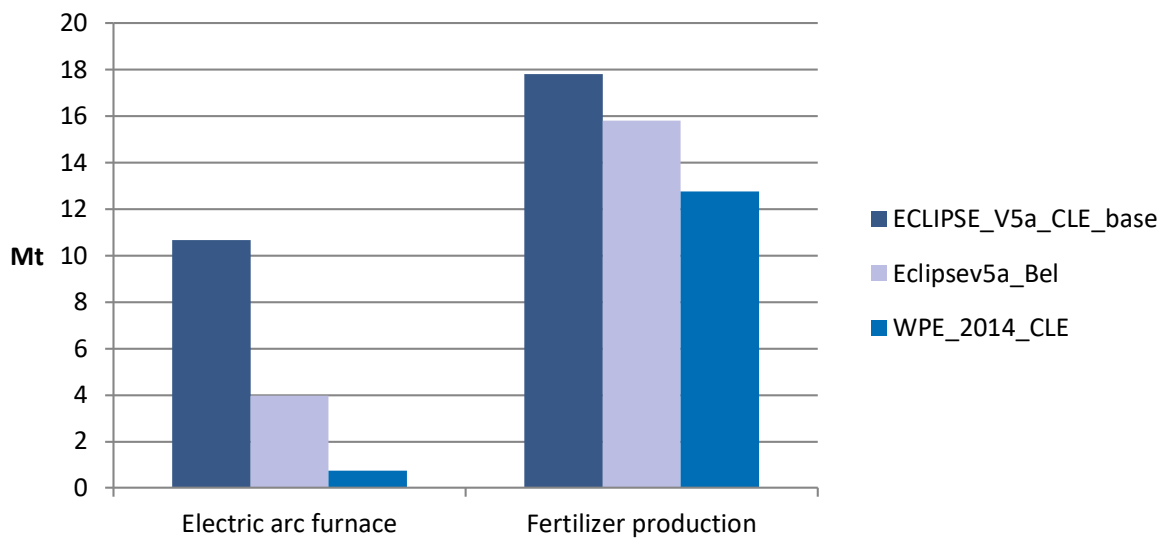

Both of the IIASA's scenarios suggest an increase in particle emissions while in the national baseline the emissions are assumed to be slightly decreased compared to the $2014 / 15$ level. The reason is the assumption on lower consumption of diesel by agricultural transport in 2030, less residential wood combustion - but mainly much better abatement in the fertilizer production processes.

Table 6 also illustrates how the modelled emissions differ from the national emission inventories and projections. The $\mathrm{PM}_{2.5}$ emissions as in the previous emission inventory for 2014 are about $44 \%$ lower than the lowest number for 2015 , obtained in the GAINS model with the considered scenarios. The $\mathrm{PM}_{2.5}$ emissions in the improved inventory are slightly closer to the modelled emissions. Emissions of BC are $16 \%$ lower in the emission inventory (3.87 ktonnes) than in the baseline scenario Eclipsev5a_Bel (4.6 ktonnes). The main reasons for these discrepancies are the following:

- Emission sources included - both national inventories miss certain sectors and activities present in the GAINS model (e.g. certain types of waste incineration, emissions from handling of products and fuels, fugitive emissions); besides, in the previous inventory certain emission sources (e.g. road paving with asphalt, pulp and paper production, aviation) were omitted;

- Differences in the activity data - activity rates implied in the IIASA's scenarios are not always the same as those used by the national experts;

- Differences in the emission factors - even in the previous inventory not all emission factors were GAINS-based; the differences between the GAINS-based emission factors and the emission factors used in the improved emission inventory for certain key emission sources are analyzed in more detail in Chapter 4.5;

- Different assumptions on the application rates of technologies - even with the same GAINS-based emission factors different assumptions on abatement rates result in different emission numbers.

A detailed analysis of these discrepancies is outside the scope of the current project. However, this type of analysis should be done by national experts on a regular basis since significant differences in the emissions imply we might overestimate the 
emission reduction potential obtained with the GAINS model. Possible impact of the discrepancies on emission reduction potentials and measures depends on their reasons: e.g. missing sectors in the emission inventory may justify higher baseline emissions and modelled emission reduction potentials, while possible overestimations of emission factors in GAINS, compared to the national emission factors, would mean we also actually overestimate baseline emissions and emission reduction potentials. Since proper simulation of baseline emissions are starting point for further integrated assessment modelling, more efforts should be put to minimizing the discrepancies between these two data sets - in particular, to investigation of the reasons for observed discrepancies and to harmonization of the emissions at least at the level of the national totals.

\section{MFR scenario}

MFR scenario (Eclipsev5a_Bel_MTFR) for Belarus is developed by the national experts with respect to feasibility and market availability of abatement measures available in the GAINS model. MFR scenario includes measures for both stationary emission sources and transport (road and non-road). The MFR scenario for Belarus, as well as for the Nordic countries analysed below in the relevant chapters, are developed primarily for the $\mathrm{PM}_{2.5}$ fraction, meaning that a range of measures in these scenarios do not affect $B C$ emissions. In some activities, BC emissions do not even occur so that measures in associated sectors are not relevant for emission reduction potentials either.

Figure 14 and Figure 15 illustrate the distribution of baseline and MFR emissions in Belarus in 2030 and inputs of different sources into the emission reduction potentials, for $\mathrm{PM}_{2.5}$ and $\mathrm{BC}$, respectively. According to the modelling results, the largest source of $\mathrm{PM}_{2.5}$ emissions in 2030 is industrial processes ( 25 ktonnes), followed by residential combustion (13 ktonnes) and industrial combustion ( 7 ktonnes). The total contribution from these three sectors to the national emissions amounts to $87 \%$. The same three sectors together contribute to $94 \%$ of the emission reduction potential, which is estimated at 35 ktonnes.

Figure 14: Modelled $\mathrm{PM}_{2.5}$ baseline and MFR emissions, and emission reduction potentials in Belarus in 2030, ktonnes

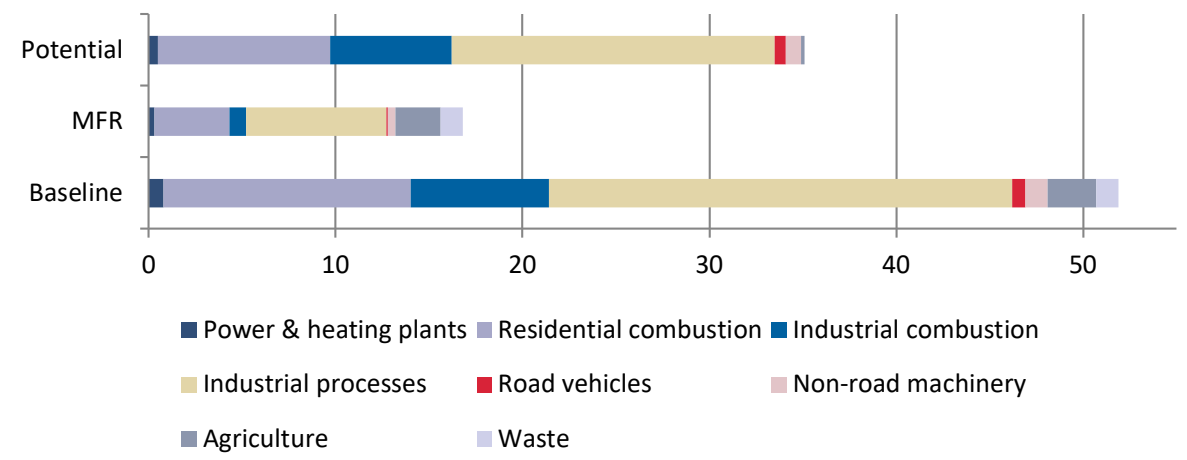


Figure 15: Modelled BC baseline and MFR emissions, and emission reduction potentials in Belarus in 2030, ktonnes

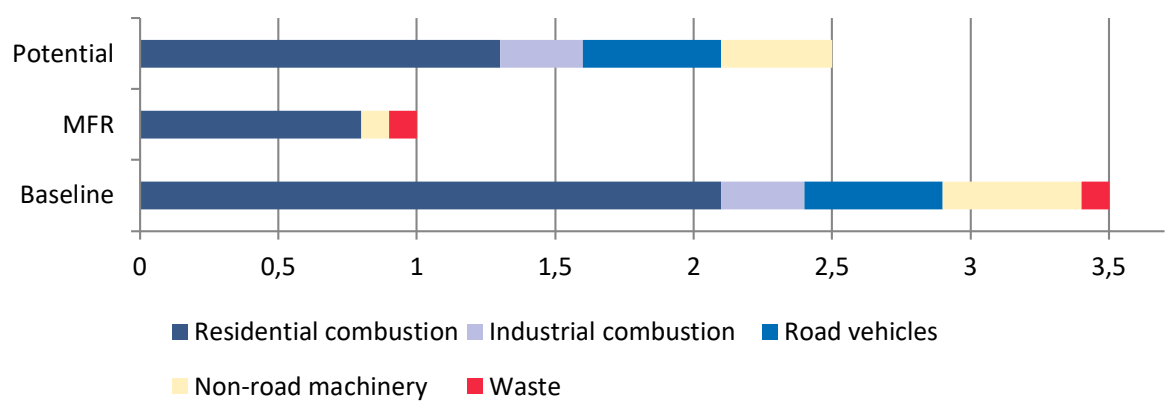

These numbers can be compared to the estimates of the emission reduction potentials for $\mathrm{PM}_{2.5}$ in 2020 made by Kakareka \& Krukowskaya (2011) where the emission reduction potential in the stationary combustion sector (except for residential sector) and industrial processes are estimated at $\sim 6$ ktonnes (here $-\sim 24$ ktonnes), in the transport sector $-\sim 2$ ktonnes (here $-\sim 1.5$ ktonnes), and for residential combustion $-\sim 3$ ktonnes (here - $\sim 9$ ktonnes). According to Kakareka \& Krukowskaya (2011), the emission reduction potential for $\mathrm{PM}_{2.5}$ corresponds to $\sim 41 \%$ of the national totals (here - 68\%) where national totals in 2020 are estimated at $\sim 27 \mathrm{ktonnes} \mathrm{PM}_{2.5 .}$. However, the estimates presented in Kakareka \& Krukowskaya (2011) are based on the elder national emission inventories, using very different principles for emission allocation and aggregation than those used in the improved inventory or in the GAINS scenarios. Like in other available emission inventories and projections (see Table 5), the total national PM2.5 emissions are much lower than those implied in the GAINS model, resulting in the lower emission reduction potential - the problem not yet resolved.

Baseline emissions of black carbon in 2030 (Figure 15) are dominated by the residential combustion sector - contributing to the total emissions by $58 \%$. Two other significant emission sources with more or less equal inputs ( 0.5 ktonnes, or $14 \%$ each) are non-road machinery and road vehicles. The same three sectors together contribute to $88 \%$ of the black carbon emission reduction potential. The total emission reduction potential is 2.5 ktonnes BC.

From the figures above it can be concluded that the largest potential to reduce particle emissions lies within the highest emitting sectors. If all most efficient available measures are applied to their possible extent in 2030, emissions of $\mathrm{PM}_{2.5}$ could be reduced by $32 \%$, compared to the baseline number. Emissions of BC could be reduced by $31 \%$.

\subsection{Cost-effective measures for $\mathrm{PM}_{2.5}$ and $\mathrm{BC}$ abatement}

To analyse available measures to reduce $\mathrm{PM}_{2.5}$ and $\mathrm{BC}$ emissions from stationary sources, we have used marginal cost curves. The method of marginal cost curve is based on the principle that abatement measures not yet implemented within the baseline scenario should be applied in the order of their cost-effectiveness, where costeffectiveness is characterized by marginal costs of each subsequent (more efficient) measure. 
The marginal cost of a measure can be defined as the extra cost for an additional measure, compared to the cost of a less efficient option. Marginal costs are calculated with Equation 1 (Klimont et.al 2002):

$$
M C=\frac{C 2 * R E 2-C 1 * R E 1}{R E 2-R E 1} \text { Equation } 1
$$

Where:

- $\mathrm{C}_{1}, \mathrm{C}_{2}$ - unit costs of two subsequent measures, EUR/tonne pollutant;

- RE1, RE2 - removal efficiencies of two subsequent measures, \%.

All measures with reduction potential are first ranked by their marginal costs. Measures are then added to the scenario one by one, replacing already employed less efficient measures. The method is described more in detail in e.g. Klimont et.al 2002 and Purohit \& Höglund-Isaksson 2017.

When all the measures are applied, the resulting level of abatement is what is assumed in the MFR scenario. A marginal cost curve can thus be described as the most cost-effective path from the baseline scenario to the MFR scenario - or to a certain emission reduction level that policy-makers wish to achieve. The baseline-to-MFR path is often referred to as "gap closure" - this concept is used in particular in the UNECE CLRTAP work (Amann 2011a).

The cost curve for PM2.5 from stationary sources in Belarus is presented in Figure 16. Marginal costs increase from 14 EUR $^{10} /$ tonne (electrostatic precipitators (ESP) in the cement industries) to $\sim 1$ million EUR/tonne (good practice in the combustion of diesel in the residential sector), and the total accumulated cost of the gap closure for stationary sources is estimated at EUR 655 million.

${ }^{10}$ Currency year 2005 is used through the present report for assessments of costs and benefits. 
Figure 16: Cost curve for $\mathrm{PM}_{2.5}$ in Belarus in 2030

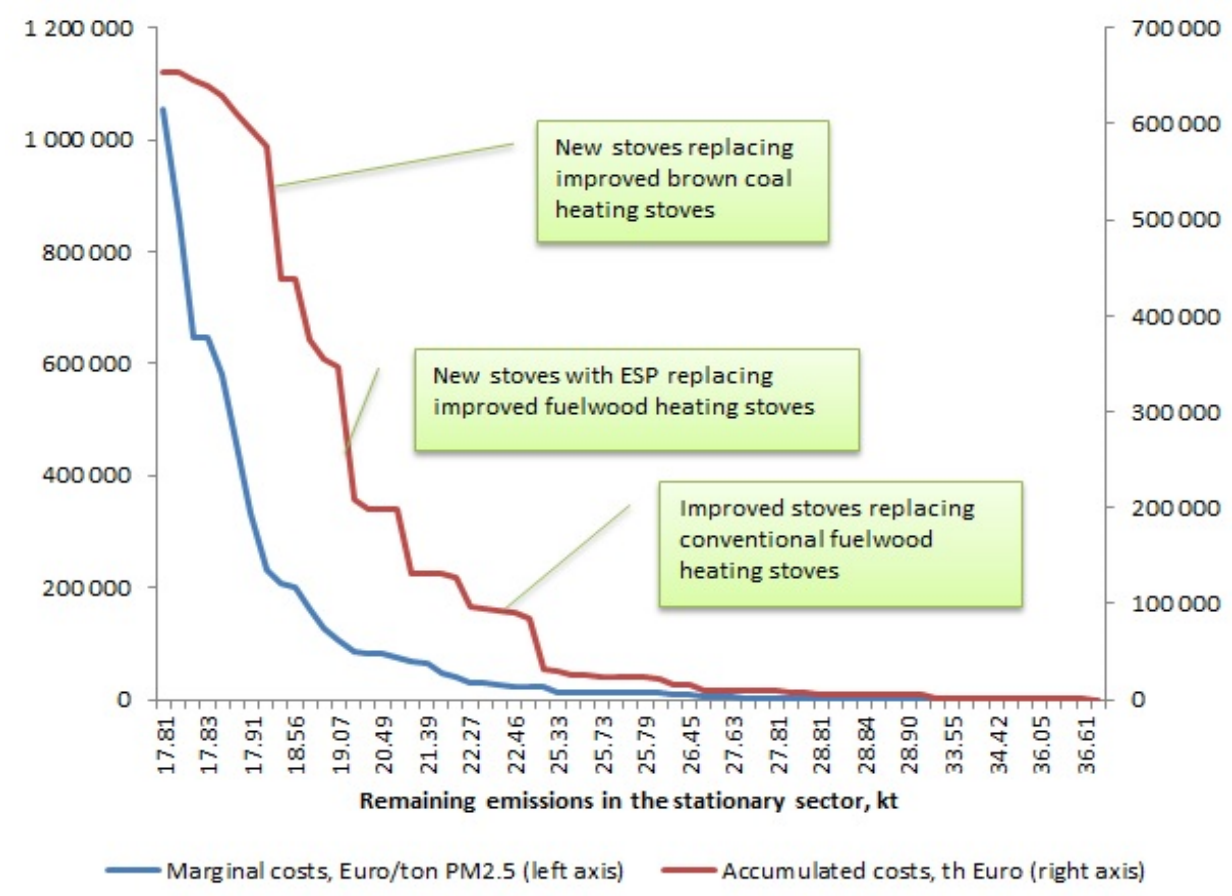

All the measures available for $\mathrm{PM}_{2.5}$ emission reduction from stationary emission sources are specified in Annex 4 which describes the presented curve in more details. Some of the measures result in visible leaps in the marginal or total costs or both - these are mostly due to the application of more advanced technologies in the residential combustion sector.

From a policy perspective, it is usually more interesting to investigate "emission plateaus" - fragments of a curve where high emission reductions are achieved with relatively low costs, located closer to its right end. Figure 17 presents such a fragment indicating that in Belarus about 15 ktonnes of $\mathrm{PM}_{2.5}$ emissions ( $45 \%$ of the reduction potential) can be reduced by measures with very low marginal costs - replacing cyclones with ESP at industrial sites.

Figure 17: Cost curve for $\mathrm{PM}_{2.5}$ in Belarus - a fragment with low marginal cost measures

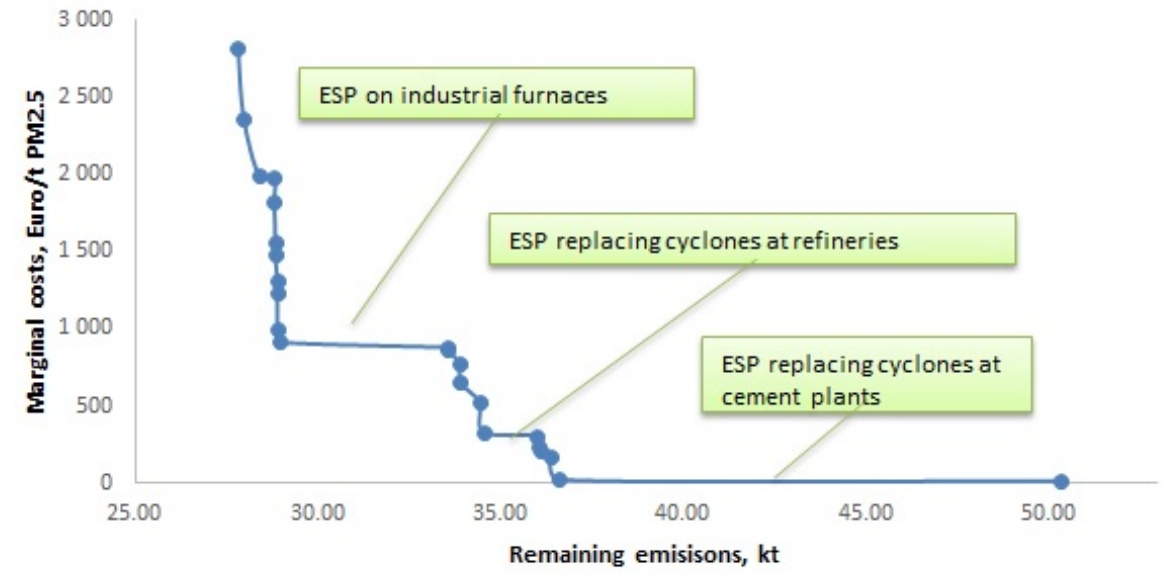


In Figure 18, a cost curve illustrating gap closure in the stationary sector for $B C$ is presented. In this curve, measures targeting $\mathrm{PM}_{2.5}$ but not $\mathrm{BC}$ are excluded so the resulting list of measures is much shorter. $B C$ reducing measures are further specified in Annex 5.

Figure 18: Cost curve for black carbon in Belarus in 2030

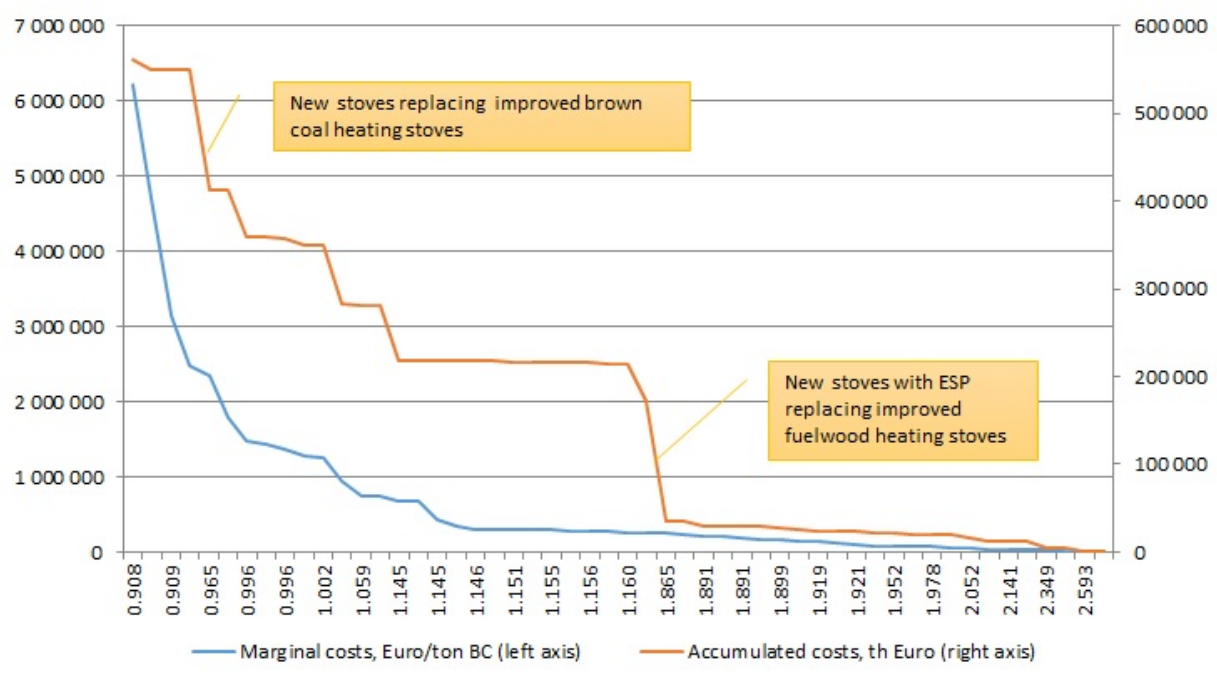

Marginal costs for BC measures increase from 9,000 EUR/tonne (ESP in the cement industries) to $\sim 6.2$ million EUR/tonne (improved fireplaces), and the total accumulated cost of the gap closure for stationary sources is estimated at EUR $\sim 560$ million. Note that this number is $14 \%$ lower than the total cost for $\mathrm{PM}_{2.5}$ gap closure (EUR 655 million) since fewer measures need to be included. $\mathrm{BC}$ marginal costs for measures also relevant for $\mathrm{PM}_{2.5}$ are higher than $\mathrm{PM}_{2.5}$ marginal costs: virtually all the measures have lower reduction efficiencies for $B C$ so that removal of one additional tonne of $B C$ costs more than removal of one additional tonne of $\mathrm{PM}_{2.5}$.

Cost leaps for $\mathrm{BC}$ abatement, similar to the leaps in the $\mathrm{PM}_{2.5}$ Curve, are observed for measures in the residential combustion - mostly replacing coal and fuelwood stoves with more advanced appliances. "Emission plateaus" for BC are shown in Figure 19. Measures that significantly reduce emissions with relatively low marginal cost increase are ESP on industrial furnaces ( 0.35 ktonnes, or $15 \%$ of the emission reduction potential) and more advanced boiler installations. 
Figure 19: Cost curve for black carbon in Belarus - a fragment with low marginal cost measures

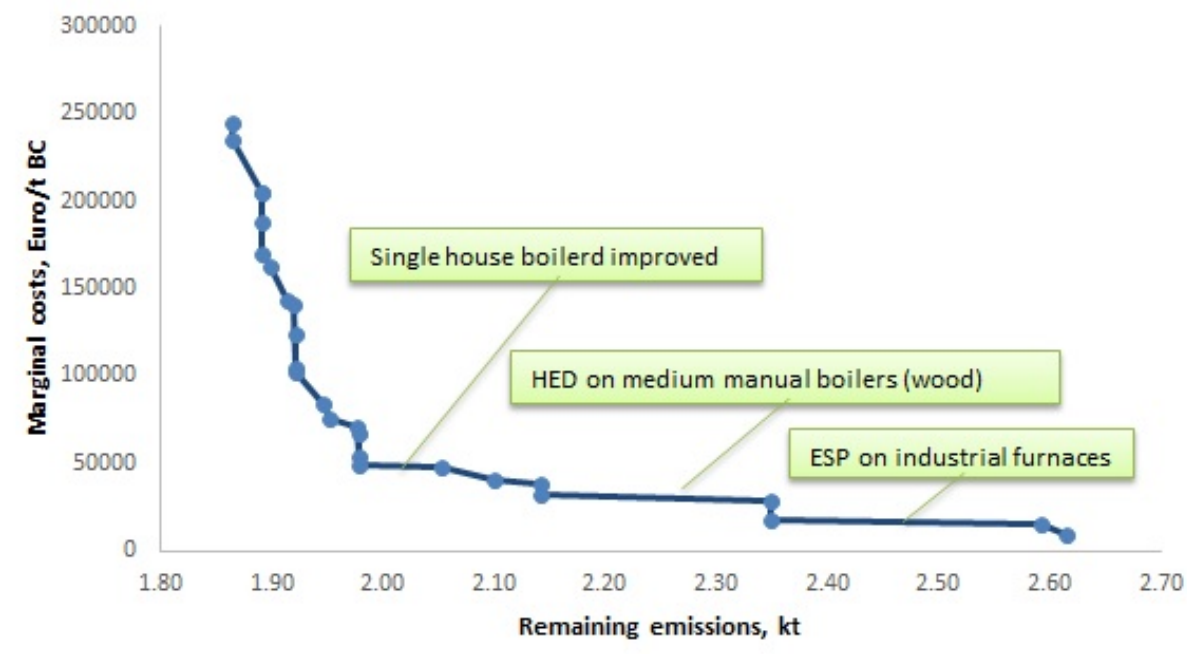

Measures available in the transport sector are not included in the presented cost curves due to the complexity of unit cost calculations in this sector; however, emission reduction potential in the transport sector is significant for black carbon, and available measures should not be neglected. The MFR scenario for Belarus implies the following measures for road and non-road diesel mobile sources:

- Agricultural transport, railways: $90 \%$ of Stage 5 control;

- Buses and heavy duty vehicles: $90 \%$ of Euro $\mathrm{Vl}_{\text {; }}$

- Passenger cars: $90 \%$ of Euro 6 .

Implementation of these measures in the transport sector would bring the additional 1.4 ktonnes reduced $\mathrm{PM}_{2.5}$ and 0.9 ktonnes reduced $\mathrm{BC}$, on top of the measures for the stationary sources. The total costs of abatement in this sector amount to EUR 450 million - almost as high as costs of reducing emissions from the stationary sources only.

The main purpose of the cost curve compilation is providing decision-makers and scientists with a tool that enables identification of measures necessary to reach a certain emission reduction ambition level - or to assess the possible level of emission reductions within certain budget limitations. Since application of the curve always results in the most cost-effective choice of measures, it may be considered as a onedimension optimization procedure that minimizes costs for given emission reduction targets. The resulting measures and their costs would depend on the prioritized particle fraction. As an example, a set of measures for the target "10\% gap closure" (realization of $10 \%$ of the emission reduction potential) would differ a lot depending on whether this target is set for $\mathrm{PM}_{2.5}$ or $\mathrm{BC}$. Although the total gap closure for $\mathrm{BC}$ costs less than for $\mathrm{PM}_{2.5}$, for a small decrease of $\mathrm{PM}_{2.5}$ less costly measures might be available, whereas for $B C$ the number of measures is much more limited, and the curve might start with more expensive measures (see the specification of the measures in Annex 4 and Annex 5). 
Following the UNECE CLRTAP recommendations and prioritizing $B C$ emissions in the efforts to reduce $\mathrm{PM}_{2.5}$ would mean targeting only $\mathrm{BC}$ emitting sectors (and excluding e.g. agriculture where $B C$ is not relevant) and choosing measures only from the $B C$ cost curve instead of often cheaper measures that do not have any effect on $B C$. For the same $\mathrm{PM}_{2.5}$ reduction target, a set of cost-effective measures with and without respect to their effect on $B C$ emissions would look different and result in different technical costs. Measures prioritizing BC would cost more - but also bring more benefits to population health from reduced emissions of this harmful fraction.

\subsection{Gap closure in the stationary sector - possible ambition levels for policy decisions}

Emission reductions to the level of MFR are a highly unlikely scenario for most countries since it is inevitably associated with very high costs. To investigate more realistic options, we've chosen several ambition levels corresponding to a certain percentage of emission gap closure, or realization of the emission reduction potential for $\mathrm{PM} 2.5$ from stationary sources:

- Low - 40\% of emission gap closure;

- Medium (mid) - $60 \%$ of emission gap closure;

- High - 90\% of emission gap closure;

- MFR_st - MFR is fully implemented, but for stationary emission sources only.

We've developed a GAINS model scenario for each of these ambition levels so that together with baseline and MFR there are thus six different scenarios further analysed in the present study in terms of emissions, health effects, costs and benefits.

Sets of abatement measures for reaching each of the ambition levels are chosen based on the cost curve (Figure 16), the specification of which is presented in Annex 4. As noted above, these measures are the most cost-effective ones; however, no priority is made to measures targeting $B C$.

Figure 20 illustrates emissions of $\mathrm{PM}_{2.5}$ and $\mathrm{BC}$ from stationary sources in the five considered scenarios. The emission difference between the baseline and the low ambition level is 15 ktonnes $\mathrm{PM}_{2.5}$. It is interesting that the emission reduction target for $\mathrm{PM}_{2.5}$, included by Belarus in the revised Gothenburg protocol under the UNECE CLRTAP in 2012, corresponds to the low ambition level specified in the present study, under the assumption of the target year 2030 instead of $2020 .{ }^{11}$

\footnotetext{
${ }^{11}$ In the revised Gothenburg protocol (2012), the 10\% emission reduction target, compared to the level of 2005, is specified for Belarus. Applying this to the national GAINS baseline (46.3 kt PM2.5 in 2005) means emission level of $41.7 \mathrm{kt}$ in 2030 . The difference between baseline emission level in this scenario (52.0 kt) and $41.7 \mathrm{kt}$ is $10.3 \mathrm{kt}$, which corresponds to $29 \%$ of the estimated emission reduction potential in the stationary sector (35.2 kt) - still within the low ambition level.
} 


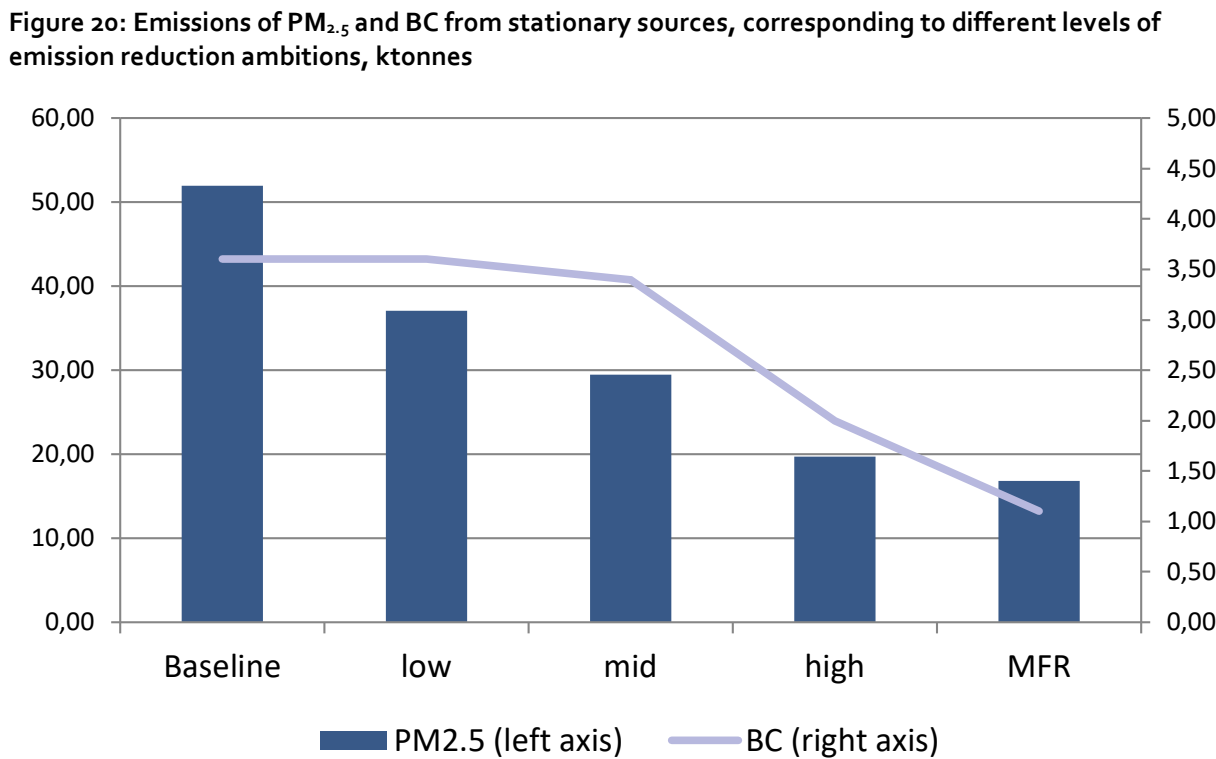

As follows from the figure, reducing $\mathrm{PM}_{2.5}$ down to $\sim 60 \%$ emission gap closure would not affect $B C$ reductions to a significant extent. At this level, $B C$ emissions virtually have not been changed - due to the fact that most cost-effective measures for $\mathrm{PM}_{2.5}$ are much less efficient for $\mathrm{BC}$. The high ambition level for $\mathrm{PM}_{2.5}$ corresponds to $64 \%$ of $\mathrm{BC}$ emission reduction potential realization. $60 \%$ realization of $B C$ emission reduction potential ( 2.1 ktonnes remaining emissions) lies somewhere between the medium and high ambition levels for $\mathrm{PM}_{2.5}$.

Different paces of emission reductions for $\mathrm{BC}$ and $\mathrm{PM}_{2.5}$ observed in this approach are important for developing air pollution abatement strategies aimed at finer fractions than just $\mathrm{PM}_{2.5}$. Choice of abatement measures based on cost-effectiveness of available PM2.5 measures does not seem to result in significant reductions of $B C$ unless a rather high ambition level is chosen. To reduce $B C$ fractions more quickly, one should rather follow a specific $B C$ cost curve (Figure 16, Annex 5), or a kind of $\mathrm{PM}_{2.5}$ cost curve where $B C$ measures are prioritized (discussed in Chapter 4.2, not included in the study). If $B C$ emissions are not considered important in the policy-making, the $\mathrm{PM}_{2.5}$ cost curve would provide decision-makers with the most cost-effective solutions.

\subsection{Cost-benefit analysis}

For cost-benefit analysis (CBA), we apply an approach similar to the one used by the UNECE CLRTAP and by the European Commission (see CBA for policy options for the revision of the Gothenburg protocol in Holland et al. 2011 and CBA of Final Policy Scenarios for the EU Clean Air Package in Holland 2014). The method for calculation of technical costs in the GAINS model is described in Klimont et.al 2002 and Bosch et.al 2009. The total costs comprise investment costs and operation and maintenance costs. Investment costs are annualised with Equation 2 (Bosch et al. 2009): 


$$
I_{a n}=I * \frac{(1+q)^{l t} * q}{(1+q)^{l t}-1} \text { Equation } 2
$$

Where:

- $\mathrm{I}_{\mathrm{an}}=$ Annual investment costs;

- $\quad \mathrm{I}=$ Total investment costs;

- $\mathrm{q}=$ Investment interest rate (shares);

- $\quad$ It = Investment lifetime (years).

Figure 21 displays sector-specific costs of abatement measures for considered emission reduction ambition levels. The total costs of the gap closure amount to EUR 943 million, with the highest costs (EUR 382 million) attributable to the residential sector. Sectorspecific costs per $\mathrm{kg}$ removed $\mathrm{PM}_{2.5}$ for different ambition levels are shown in Table 7 .

Figure 21: Sector-specific costs for MFR scenario ("gap closure") in Belarus, 2030, million EUR

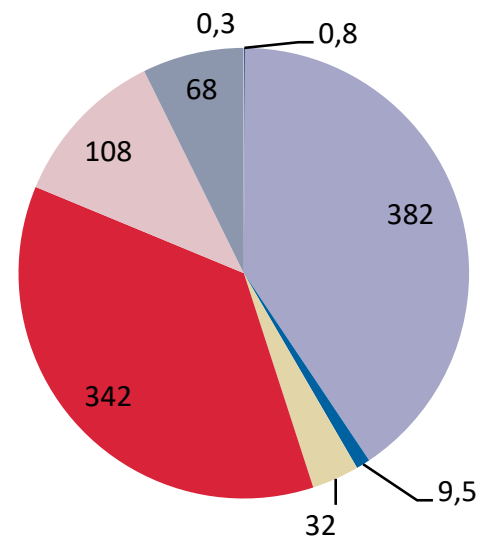

$$
\begin{aligned}
& \text { Power \& heating plants } \\
& \text { Residential combustion } \\
& \square \text { Industrial combustion } \\
& \text { Industrial processes } \\
& \text { Road vehicles } \\
& \text { Non-road machinery } \\
& \text { Agriculture } \\
& \text { Waste }
\end{aligned}
$$

Table 7: Sector-specific costs for different ambition levels for $\mathrm{PM}_{2.5}$ emission reductions in Belarus, 2030, EUR/kg PM 2.5

\begin{tabular}{lrrrrr} 
Sector & low & mid & high & MFR_st & MFR \\
Power \& heating plants & - & 0.25 & 1.60 & 1.60 & 1.60 \\
Residential combustion & - & 0.50 & 29 & 42 & 42 \\
Industrial combustion & - & 0.80 & 1.49 & 1.46 & 1.46 \\
Industrial processes & 0.01 & 0.04 & 0.38 & 1.85 & 1.85 \\
Road vehicles & - & - & - & - & 570 \\
Non-road machinery & - & - & - & - & 135 \\
Agriculture & - & - & - & 342 & 342 \\
\hline
\end{tabular}

By benefits in this study we mean reduced costs of adverse health effects caused by air pollution via exposure of population to fine particles $\left(P M_{2.5}\right)$. For calculation of benefits, the ALPHA RiskPoll (ARP) economic valuation model is used (Holland et al. 2013). The ALPHA RiskPoll model enables analysis of a wide range of chronic and acute health effects from exposure to fine particles, ozone and nitrogen dioxide. As an input, the model uses country-specific and scenario-specific population-weighted average concentrations. These can be calculated in the GAINS model, where certain health 
effects are also visualized in maps. As an example, in Figure 22 the statistical life expectancy loss in the European population in 2030 is shown for the baseline and MFR ${ }^{12}$ scenarios. Longer life expectancy in MFR is seen in particular in the Southern parts of Sweden and Finland and in the South-Western part of Belarus.

Figure 22: Statistical life expectancy loss (month) due to exposure to secondary $\mathrm{PM}_{2.5}$ in 2030

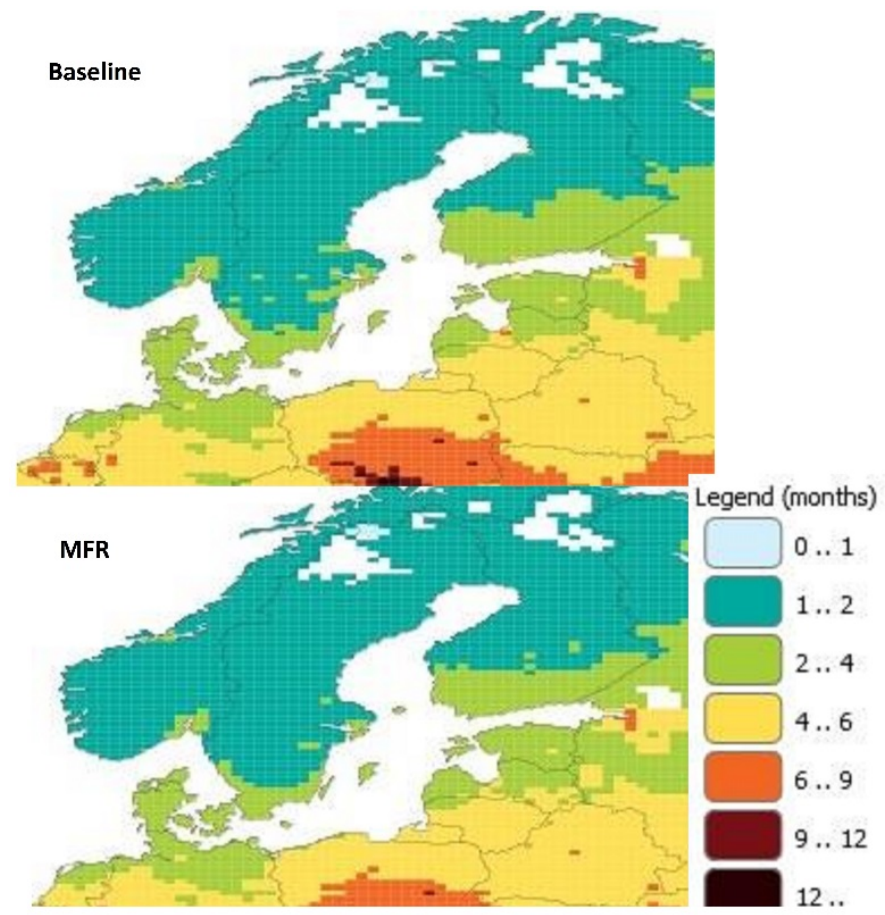

Country-specific population-weighted $\mathrm{PM}_{2.5}$ is introduced to the ALPHA RiskPoll for further calculation of health impacts and their monetary valuation. The health impact with highest monetary value is avoided mortality (fatality), which is valued by either estimating the Value of Statistical Life (VSL) or the Value of Life Year lost (VOLY). ${ }^{13}$ Giving the large differences between the VOLY and the VSL approaches, we present the resulting benefits valued in both metrics.

CBA results for Belarus, presented in Figure23, indicate that even at the high level of ambition in emission reductions, benefits remain higher than costs irrespective of the chosen metric. If all available measures are taken for stationary sources, benefits might be lower than costs if expressed in VOLY and if we only look at the positive impacts inside the country. In case of the fully implemented MFR scenario, benefits both inside and outside the country are still higher than costs if we chose VSL as the main valuation metric. This means, it's in principle always cost-effective for Belarus to reduce its particle emissions to the level corresponding to $90 \%$ of the "gap closure" (by $\sim 32$ ktonnes $\mathrm{PM}_{2.5}$ ), while closer to the maximum possible emission reduction the result

\footnotetext{
${ }^{12}$ MFR in both Belarus and in the three considered Nordic countries.

${ }^{13}$ The VOLY and VSL approaches differ in terms of how many life years that are assumed to be lost when a fatality occurs. The VOLY method is based on life tables; it takes into account at what age people die from air pollution and gives results in terms of life expectancy. The VSL method does not use life tables and instead operates with mortality rates. As the VSL method does not take into account age or death reasons, it is sometimes considered to be overestimating health benefits from air pollution reduction (Desaigues et al. 2011) while VOLY approach is considered as more conservative.
} 
depends on whether VSL or VOLY is chosen for valuation of the health effects and whether reduction of the adverse health effects in the neighbouring countries (especially Russia, Ukraine an Poland) are included.

Figure 23: Costs and benefits for different ambition levels for $\mathrm{PM}_{2.5}$ emission reductions

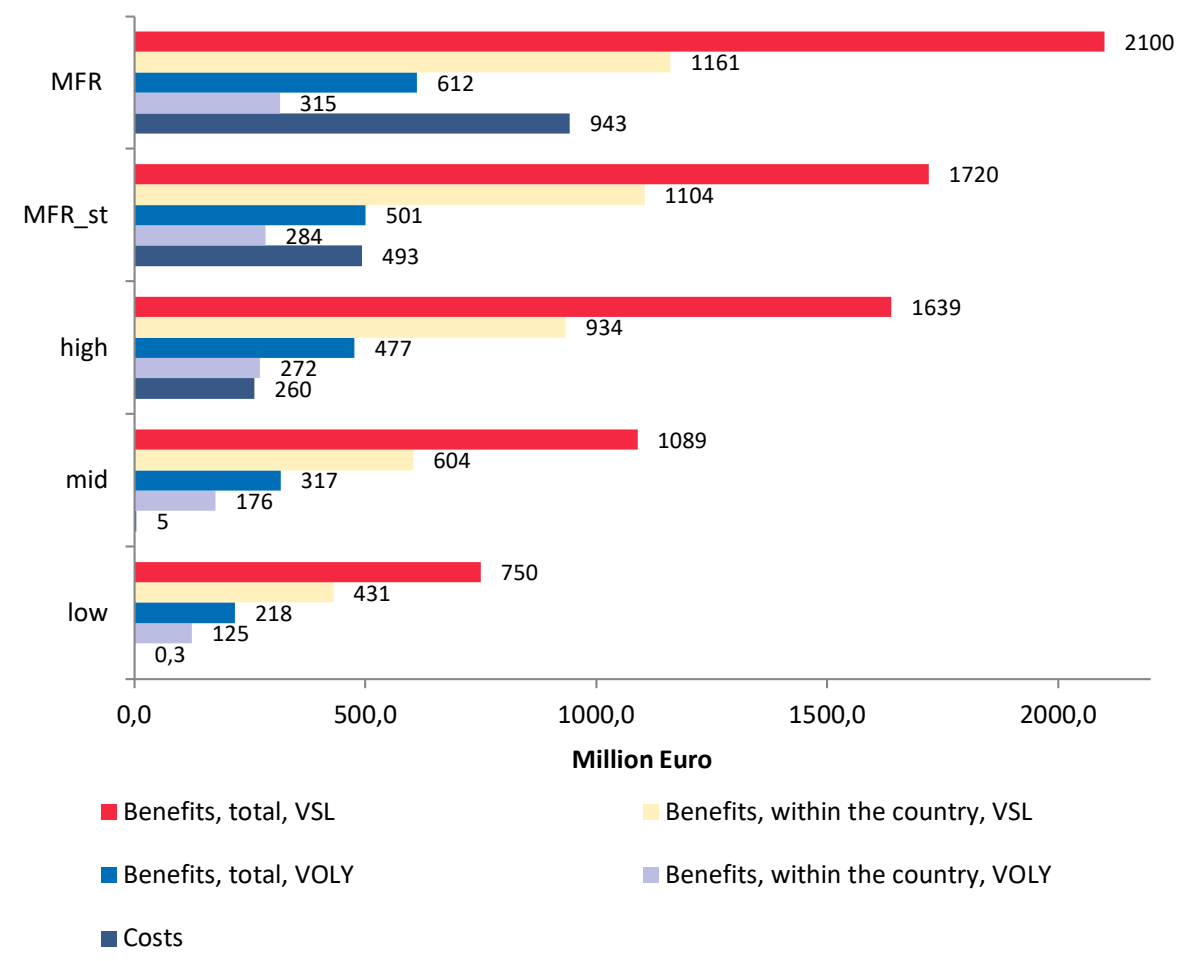

It is also important to remember that not all negative health effects are included in the ARP model: in particular, adverse effects on health specifically from black carbon (WHO 2012) are not considered. This means, health benefits in this study are underestimated. Besides, all other possible environmental impacts except for health-related are excluded from this analysis, resulting in even more underestimation of the total benefits from reductions of particle emissions.

\subsection{Alternative emission factor datasets for key emitting sources in Belarus}

Discrepancies between emissions obtained with the GAINS model and the reported/projected emissions for the same year are often large and caused by differences in both activity data and emission factors. Emission factors in the GAINS model are basically technology-specific and linked to assumed application rates of different technologies in a specific year, assumed by a user. In the emission inventories, on the other hand, it is very common to use weighted average values such as default emission factors presented in the EMEP/EEA Guidebook. The Guidebook is regularly updated and comprises the most recent knowledge regarding emission factors. Default emission factors, however, do not always reflect the variety of available abatement technologies and their impact on shares of the black carbon fraction in $\mathrm{PM}_{2.5}$ (which 
actually is very sensitive to applied abatement). Only country experts can make conclusions on whether the mix of technologies implied in the default emission factors is representative for a particular country. Besides, not all countries have resources to analyse the status of abatement in the future or/and in the past. IIASA experts also work to incorporate the results of the latest research in the model - but this work is not always coordinated with the EMEP/EEA Guidebook updates, and not all countries are of the same priority in terms of updating their values. All of this results in persisting differences between modelled emissions and emission inventories and projections.

To analyse how much the proper choice of emission factor affects the results of the modelling, we have simulated model calculations using alternative sets of emission factors for key emitting sources - those derived from the EMEP/EEA Guidebook. default emission factors but adjusted to the technologies available in the GAINS model.

For simulation calculations, we have chosen $\mathrm{PM}_{2.5}$ emissions from several industrial processes and $\mathrm{BC}$ emissions from heating stoves in the residential sector. These sources make a significant contribution to the total emissions in Belarus, according to the emission inventory and the modelling results.

\subsection{1 $\quad P M_{2.5}$ emissions from Industrial processes}

The main emitting industrial processes in Belarus are cement production, lime production, steel production in electric arc furnaces (EAF), and fertilizer production. The alternative sets of $\mathrm{PM}_{2.5}$ emission factors for these processes are derived in the following way:

1. Abatement technologies available for each considered sector according to the GAINS model are linked to application rates as implied in the EMEP/EEA Guidebook. (application rates are provided directly by the developers of the Guidebook);

2. Each technology-specific emission factor is presented as a variable calculated via a "no control" emission factor and the relevant removal efficiency - here it is implied that the removal efficiencies of technologies assumed in the Guidebook are the same as in the GAINS model;

3. The weighted average emission factor is first presented as a sum of technologyspecific emission factors (the result of step 2) multiplied by related application rates (obtained at step 1 ) and then adjusted so that it has the same value as the default emission factor in the EMEP/EEA Guidebook;

4. The "no control" emission factor corresponding to the value obtained at step 3 is used to calculate all other technology-specific emission factors.

To derive alternative emission factors for black carbon, the same principle is used. Default BC emission factors based on the EMEP/EEA Guidebook are calculated as $\mathrm{PM}_{2.5}$ default emission factors multiplied by the relevant shares $B C / P M_{2.5}$ then steps $2-4$ are applied.

The resulting alternative emission factors are summarized in Annex 6. Annex 6 also specifies the EMEP/EEA Guidebook default emission factors, application rates of abatement technologies implied in the default emission factors, estimated 
technology-specific BC shares, and current (used in GAINS) and alternative emission factors for $\mathrm{PM}_{2.5}$ and $\mathrm{BC}$.

All alternative emission factors are significantly lower than those currently used in the GAINS model (Klimont et al. 2002). For fertilizer production, the unabated alternative emission factor differs from the current emission factor by a factor of $100-$ the largest difference for the four considered industries (the smallest is a factor for steel production). These differences probably arise from different assumptions regarding current abatement rates and removal efficiencies of technologies implied in the EMEP/EEA Guidebook-based emission factors and in the GAINS model.

The differences in emission factors logically result in lower emissions when simulated with the alternative emission factors - these are presented in Figure 24. The simulated emissions are lower in both baseline and MFR scenarios, and as with the higher level of abatement in MFR the emission difference becomes smaller, it results in much lower emission reduction potentials for $\mathrm{PM}_{2.5}$ if estimated with the alternative emission factors.

Figure 24: Baseline and MFR PM $2.5_{2}$ emissions in Belarus, 2030, with current and alternative emission factor sets
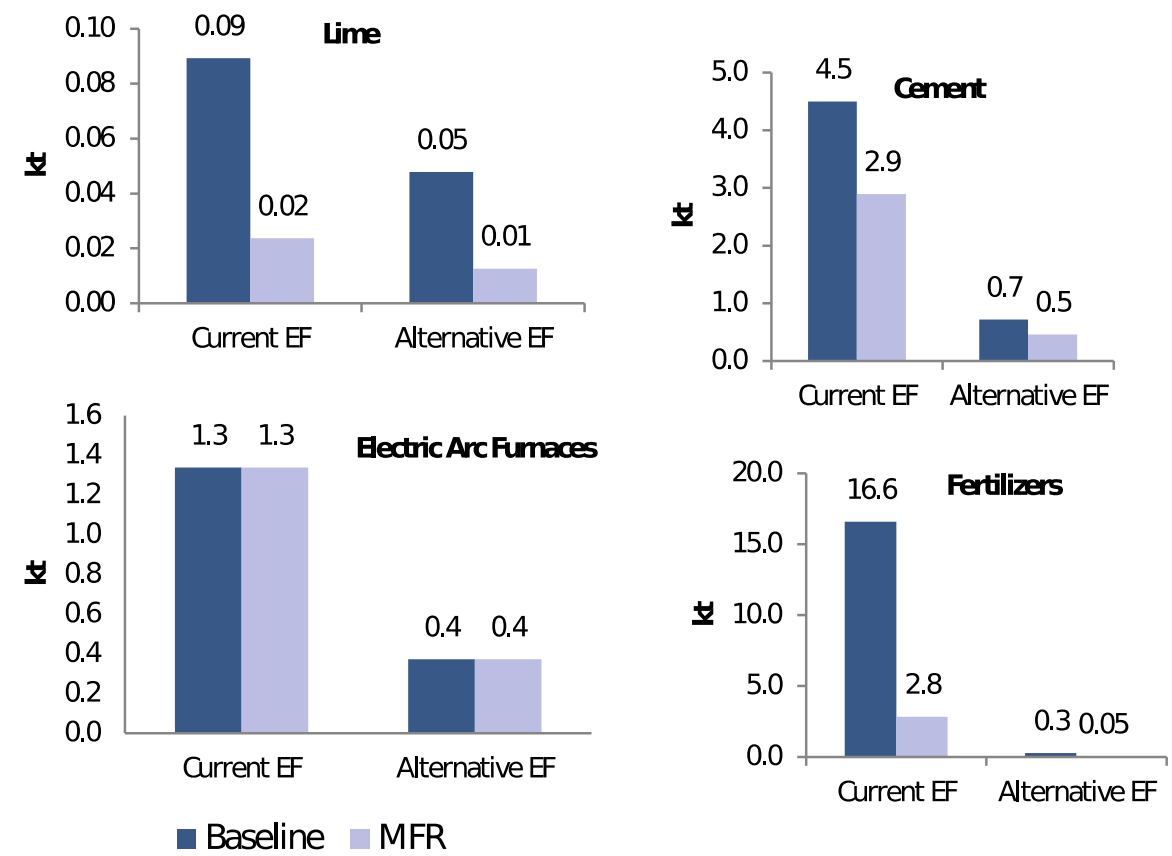

Applying the alternative emission factors for these sectors instead of those currently used in the GAINS model would also result in the different ranking of the key emitting sources - this is illustrated in Figure 25 . With the alternative emission factors, industrial processes would no longer be the largest but the third largest emitting source - after residential combustion and industrial combustion. The total baseline $\mathrm{PM}_{2.5}$ emissions would, in this case, be around 31 ktonnes $-40 \%$ lower than 52 ktonnes in the baseline scenario explored in this study, and much closer to the estimates in the national emission inventories and projections. The potential effect of the alternative emission factor set on the cost-effectiveness of different emission reduction ambition levels has not been analysed - but giving significant changes in the total national $\mathrm{PM}_{2.5}$ emissions 
and their sectoral structure it is reasonable to assume that using different emission factors would affect both the cost curve and the cost-benefit analysis results.

Figure 25: Sectoral structure of the baseline $\mathrm{PM}_{2.5}$ emissions with the two different emission factor sets

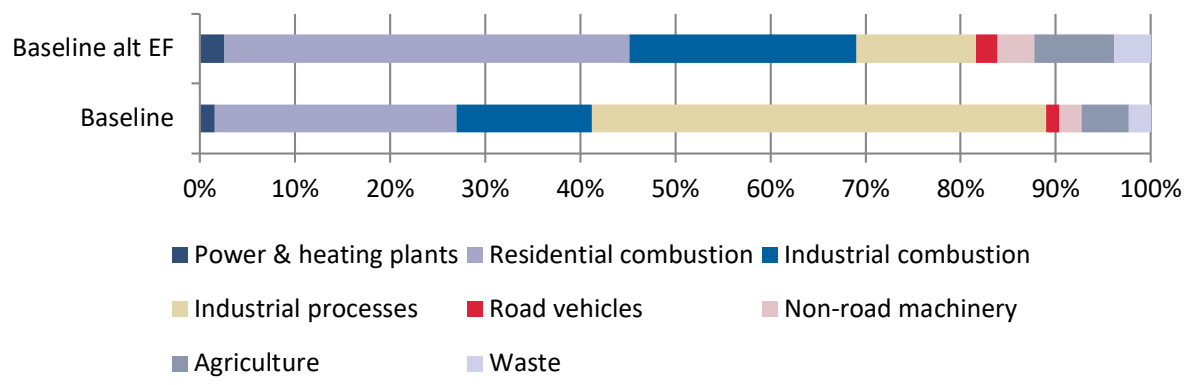

The results of the simulation presented above are only one example of how different emission factors may affect the modelling results, including assessments of emission reduction potentials. In Chapter 4.1, there is another example where the emission reduction potentials estimated based on national numbers (Kakareka \& Krukowskaya (2011)) are much lower than the reduction potentials estimated with national scenarios, also presented in Chapter 4.1.

\section{4:5.2 Black carbon emissions from wood fuel heating stoves}

Default emission factors for heating devices in the EMEP/EEA Guidebook are structured in a similar way as emission factors in the GAINS model: they are specified per device type, or category. In particular, heating stoves are divided into the following categories, in the order of descending emission factors:

- Conventional stove (corresponds to the same category in GAINS);

- Energy-efficient stove (corresponds to "improved" in GAINS);

- Advanced/eco-labelled stove (corresponds to "new" in GAINS);

- Pellets stove (corresponds to the same category in GAINS).

In the EMEP/EEA Guidebook, emission factors are average values for all countries while in the GAINS model they are country-specific. For emission simulations, we replace current country-specific emission factors in GAINS with general default emission factors per stove category. Emission factors for $B C$ are calculated as shares of $B C / P M_{2.5}$ multiplied by relevant emission factors for $\mathrm{PM}_{2.5}$.

Annex 7 summarizes current and alternative emission factors for $B C$ that are specified by stove category and by country. For Belarus, alternative emission factors for $\mathrm{PM}_{2.5}$ from conventional and improved devices seem to be higher than current GAINS emission factors, while for black carbon relevant alternative emission factors are lower due to lower ratios of $B C / P_{2.5}$.

The resulting emissions from wood fuel heating stoves in the baseline and MFR scenarios in Belarus, obtained with these two emission factors sets, are presented in Figure 26. Emissions simulated with alternative emission factors are lower than those obtained with current emission factors by $22 \%$ in the baseline and by $27 \%$ in MFR. This 
means that the emission reduction potential is lower when estimated with the alternative emission factors set -0.65 ktonnes, while using current GAINS emission factors results in 0.82 ktonnes reduction potential in 2030 .

Figure 26: BC emissions in 2030 from heating stoves in Belarus, modelled with different emission factor sets
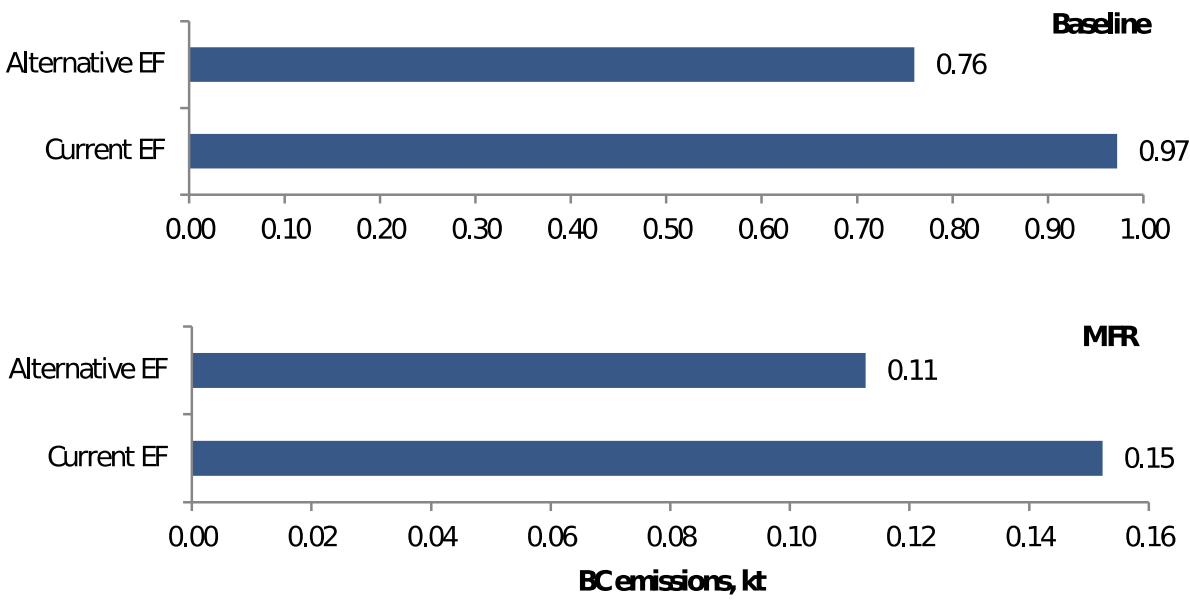

Using alternative emission factors for wood fuel heating stoves does not have a visible effect on the total national black carbon emissions. Replacing the currently used GAINS emission factors with the EMEP/EEA Guidebook-based would result in an overall reduction from 3.6 ktonnes to 3.3 ktonnes black carbon. The share of residential combustion remains virtually the same - around $58 \%$.

From the simulations with alternative emission factors and relevant examples of calculations with other emission factor sets, it can be concluded that possible discrepancies in the values of emission factors from different sources may significantly affect the resulting emission estimates. In particular, applying relatively high $\mathrm{PM}_{2.5}$ emission factors embedded in the GAINS model results in much higher baseline emissions, MFR emissions, and emission reduction potentials - compared to applying emission factors based on the defaults from the EMEP/EEA Guidebook. More efforts need to be targeted towards harmonization of the available emission data sets by the EMEP/EEA Guidebook developers and IIASA, as well as towards development of national emission factors, reflecting the current and planned status of technologies.

\section{6 $\quad \mathrm{PM}_{2.5}$ and $\mathrm{BC}$ integrated assessment for Belarus - conclusions}

The results of the integrated assessment modelling focused on $\mathrm{PM}_{2.5}$ and $\mathrm{BC}$ emissions in Belarus indicate that in 2030 sectoral structure of emissions will be similar to the structure in the latest emission inventory for 2015. The key sources of $\mathrm{PM}_{2.5}$ emissions in the country are industrial processes, whereas the largest contribution to the country's black carbon emissions is made by residential wood combustion - according to the GAINS model baseline scenario developed by national experts.

Significant emission reduction potentials are estimated for both $\mathrm{PM}_{2.5}$ and $\mathrm{BC}-35.2$ ktonnes and 2.5 ktonnes in 2030, respectively, which corresponds to $\sim 30 \%$ reduction 
compared to the baseline level. The emission reduction potential here is the emission difference between the baseline scenario and the maximum feasible reduction (MFR) scenario. The largest emission reductions can be achieved in the same sectors where the highest emission levels are projected.

Using the "gap closure" approach, we have estimated costs and benefits corresponding to low, medium and high possible emission reduction ambition levels $40 \%, 60 \%$ and $90 \%$ of gap closure, respectively. The full implementation of MFR in 2030 would require technical costs of EUR 940 million and result in societal benefits of between EUR 600 (VOLY approach) and 2,100 (VSL approach) million, mainly attributable to reduced premature mortality in the European population due to reduced exposure to $\mathrm{PM}_{2.5}$. Thus, even at the highest ambition level (MFR), in-country benefits would still overweigh costs if VSL valuation metric is used. The VOLY approach would result in the break-even point located close to the High level of ambition. Benefits within the country are estimated at about $50 \%$ of the total benefits in Europe (the other large "recipients" are neighbouring Russia, Ukraine and Poland) - considering those effects it is even more cost-effective to reduce particle emissions in Belarus.

Transport sector makes a significant contribution to black carbon emissions - this is expected to be the case also in 2030 . Without additional measures, input from diesel road and non-road sources in the total black carbon emissions in 2030 will constitute about 30\%. The costs of the emission reduction down to the MFR level by premature scrapping of diesel vehicles and fleet renewal are similar to the costs of the emission reduction at the stationary sources down to the MFR level - EUR 450 million vs EUR 490 million, respectively.

Ranking of available emission reduction measures for stationary sources by their marginal costs indicates that there is a range of measures that would allow substantial emission reductions at relatively low costs - for instance, replacing old cyclones in the cement industry and at refinery plants with ESP. The developed cost curve specifying the order of the measures by their marginal costs can be used as a basis for the development of cost-effective emission reduction strategies to reach specified emission reduction targets on the sectoral or country level.

The total national emissions of $\mathrm{PM}_{2.5}$ in 2010 and 2020/2030, as estimated in the GAINS model, are more than $40 \%$ higher than the respective numbers in the available national emission inventories and projections - partly because of the differences in the applied emission factors. From the sensitivity runs with alternative (based on the EMEP/EEA Guidebook defaults) emission factors for key $\mathrm{PM}_{2.5}$ emitting sources it can be concluded that using different sets of emission factors may significantly affect the results of the analysis - including estimates of the total baseline emissions and their sectoral structure, emissions in the MFR scenario, emission reduction potentials, and cost-effectiveness of abatement measures. There is a need for further investigation of the large discrepancies between the GAINS-based and the EMEP/EEA Guidebookbased emission factors in the key emitting sectors, and their possible harmonization in the future. An even better solution would be attempts to find necessary data (e.g. by direct contacts with industrial facilities) and to further develop national emission factors for these key sectors - and use those both in the emission inventories work and for integrated assessment modelling. 



\section{5. $\mathrm{PM}_{2.5}$ and $\mathrm{BC}$ : Integrated assessment for the Nordic countries}

Integrated assessment analysis conducted for the Nordic countries follows the same structure and principles as analysis made for Belarus (see Chapter 4 ). The main difference is that the analysis for the Nordic countries does not include a compilation of the marginal cost curve for black carbon (only for $\mathrm{PM}_{2.5}$ ) and that the methods and results are presented and discussed more briefly. In Chapter 5 we also present the results of the analysis of transboundary pollution between Belarus and the Nordic countries.

\subsection{Baseline emissions, MFR and emission reduction potentials}

In the integrated assessment modelling for the Nordic countries, we use the latest public baseline scenario developed by IIASA - ECLIPSE_V5a_CLE_base (Stohl et al. 2015) - without alterations.

In the MFR scenario, we use a combination of abatement strategies ${ }^{14}$ applied in ECLIPSE_V5a_CLE_base (Stohl et al. 2015) and in WPE_2014_CLE (Amann et al. 2015), to include all measures for both particle fractions and the most recent estimates of their maximum application rates in 2030.

Total national emissions according to the baseline and MFR scenarios, as well as estimated emission reduction potentials in 2030, are presented in Table 8.

Table 8: $\mathrm{PM}_{2.5}$ and $\mathrm{BC}$ emissions and emission reduction potentials in the Nordic countries, ktonnes

\begin{tabular}{llrrrr}
\hline Pollutant & Scenario & Denmark & Finland & Sweden & 3 countries \\
\hline \multirow{2}{*}{ PM2.5 } & Baseline & 12.8 & 24.1 & 26.8 & 63.7 \\
& MFR & 6.6 & 14.8 & 16 & 37.4 \\
& Reduction potential & 6.2 & 9.3 & 10.8 & 26.3 \\
BC & Baseline & 1.5 & 3.0 & 2.0 & 6.5 \\
& MFR & 1.0 & 2.2 & 1.3 & 4.5 \\
& Reduction potential & 0.5 & 0.8 & 0.7 & 2.0 \\
& & & & &
\end{tabular}

More detailed splits of country-specific baseline and MFR emissions and emission reduction potentials are given in Annex 8 . Sectors with the highest emission reduction potentials for $\mathrm{PM}_{2.5}$ seem to be residential combustion, power and heating plants and industrial combustion. The main contributor to the $\mathrm{BC}$ emission reduction potentials is residential combustion (more than $60 \%$ for all the Nordic countries).

${ }_{14}$ Abatement strategy in the GAINS model is a combination of abatement measures and their application rates for a specific country, sector and year. 


\subsection{Cost-effective measures for $\mathrm{PM}_{2.5}$ and $\mathrm{BC}$ abatement}

Specifications of $\mathrm{PM}_{2.5}$ abatement measures and the relevant cost curves for stationary sources compiled for the Nordic countries are presented in Annex 4. Visualization of the $\mathrm{PM}_{2.5}$ Curves is also given in Figure 27, Figure 28 and Figure 29 for Denmark, Finland and Sweden, respectively. Marginal costs for the Nordic countries vary from 64 EUR/tonne (ESP on primary aluminium plants in Sweden) to 861,300 EUR/tonne (spraying water at construction places in Finland). The largest cost leaps mostly relate to measures in the residential sector such as replacement of heating stoves with improved and pelletfuelled devices. The total accumulated gap closure costs for stationary sources are estimated at EUR 160 million for Sweden, EUR 290 million for Denmark and EUR 520 million for Finland.

Figure 27: Cost curve for $\mathrm{PM}_{2.5}$ emissions in Denmark, 2030

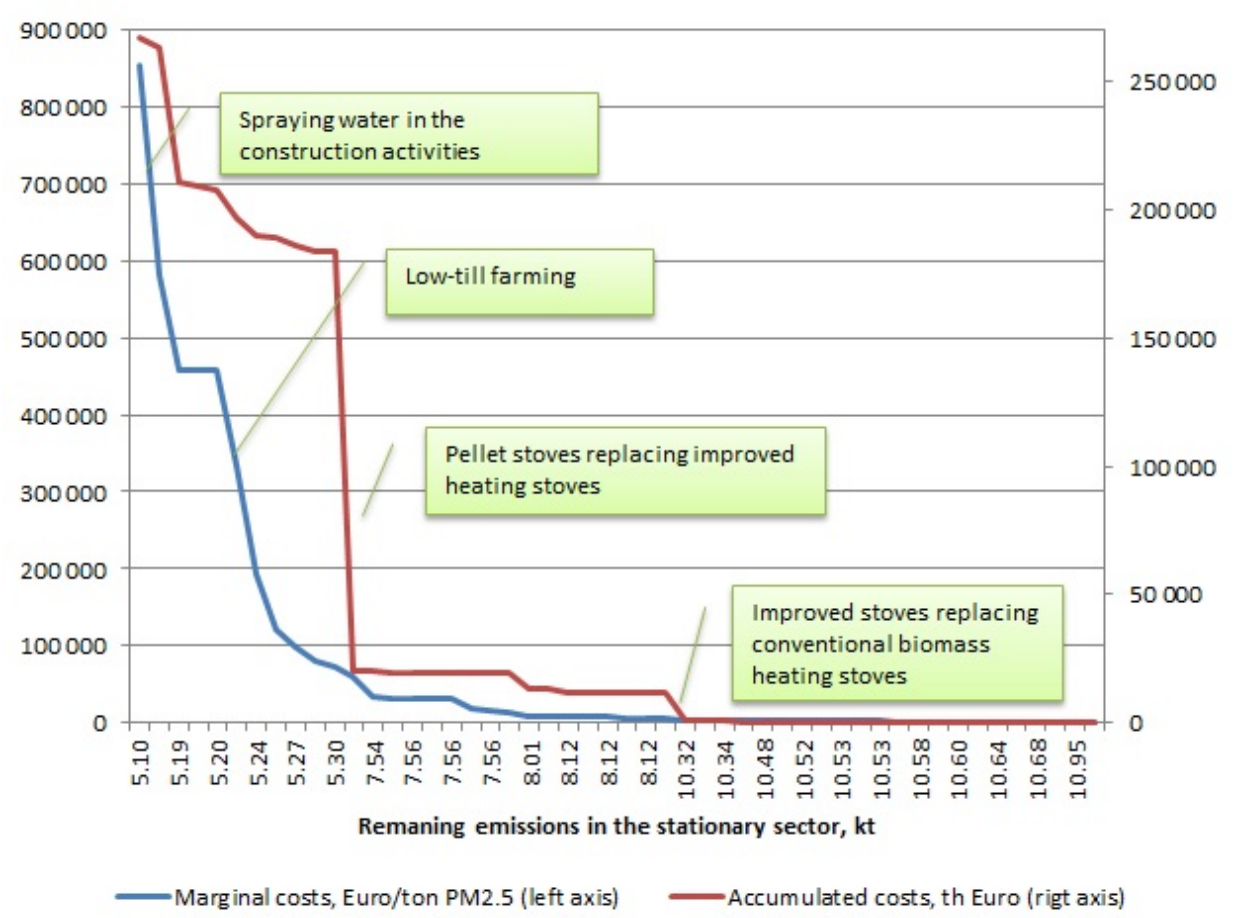

Although the cost curves for black carbon have not been developed, all the abatement measures, available for stationary emission sources according to the GAINS model, are ranked by their marginal costs (see Annex 9 ). The list of measures is shorter than the one for $\mathrm{PM}_{2.5}$ as many of the $\mathrm{PM}_{2.5}$ measures affect coarse fractions only.

The MFR scenario for the transport sector in the Nordic countries implies the following measures for road and non-road diesel mobile sources:

- Agricultural transport: $60-70 \%$ of Stage 5 control;

- Railways: $100 \%$ of Stage 4 control;

- Buses and heavy duty vehicles: $87-100 \%$ of Euro $\mathrm{Vl}_{;}$

- Passenger cars: $78-93 \%$ of Euro 6. 
Figure 28: Cost curve for $\mathrm{PM}_{2.5}$ emissions in Finland, 2030

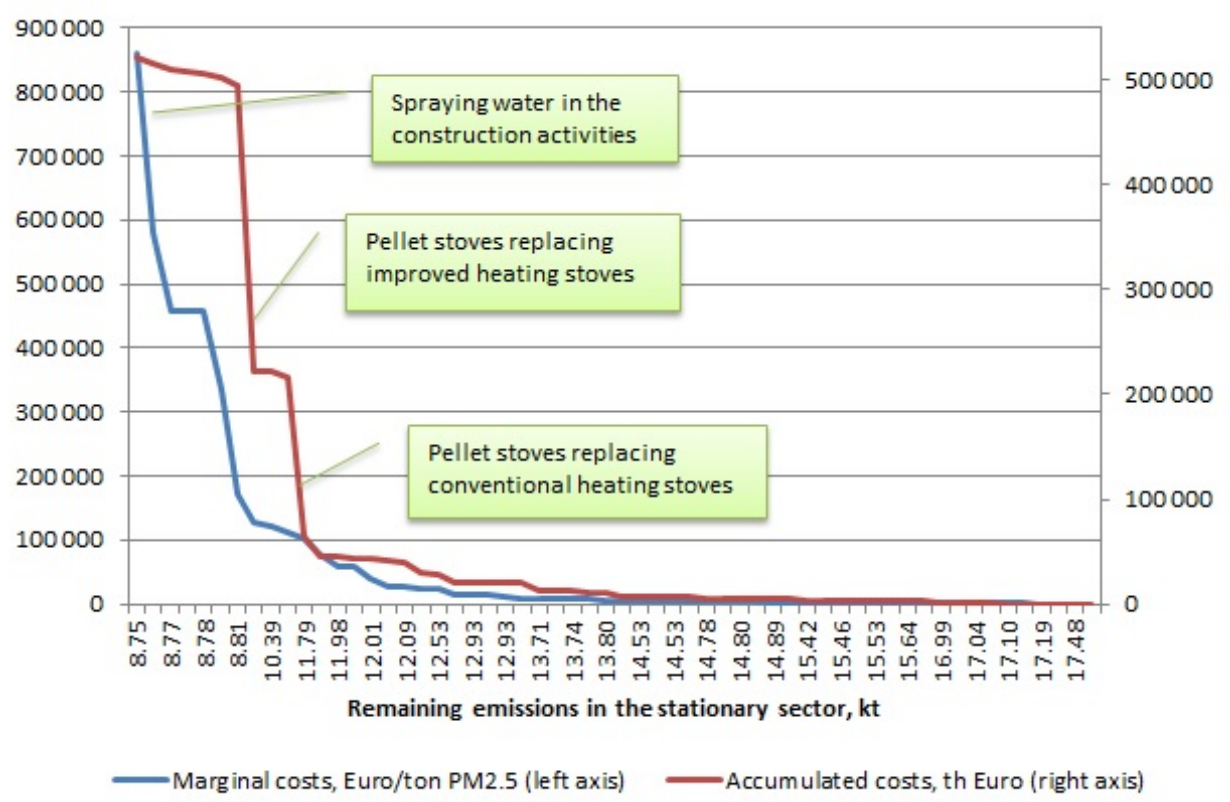

Implementation of these measures in the transport sector would bring the additional 0.9 ktonnes reduced $\mathrm{PM}_{2.5}$ and 0.3 ktonnes reduced $\mathrm{BC}$ (all three countries together), on top of the measures for the stationary sources. The total additional cost of the abatement in this sector in one country amounts to EUR 17-22 million.

Figure 29: Cost curve for $\mathrm{PM}_{2.5}$ emissions in Sweden, 2030

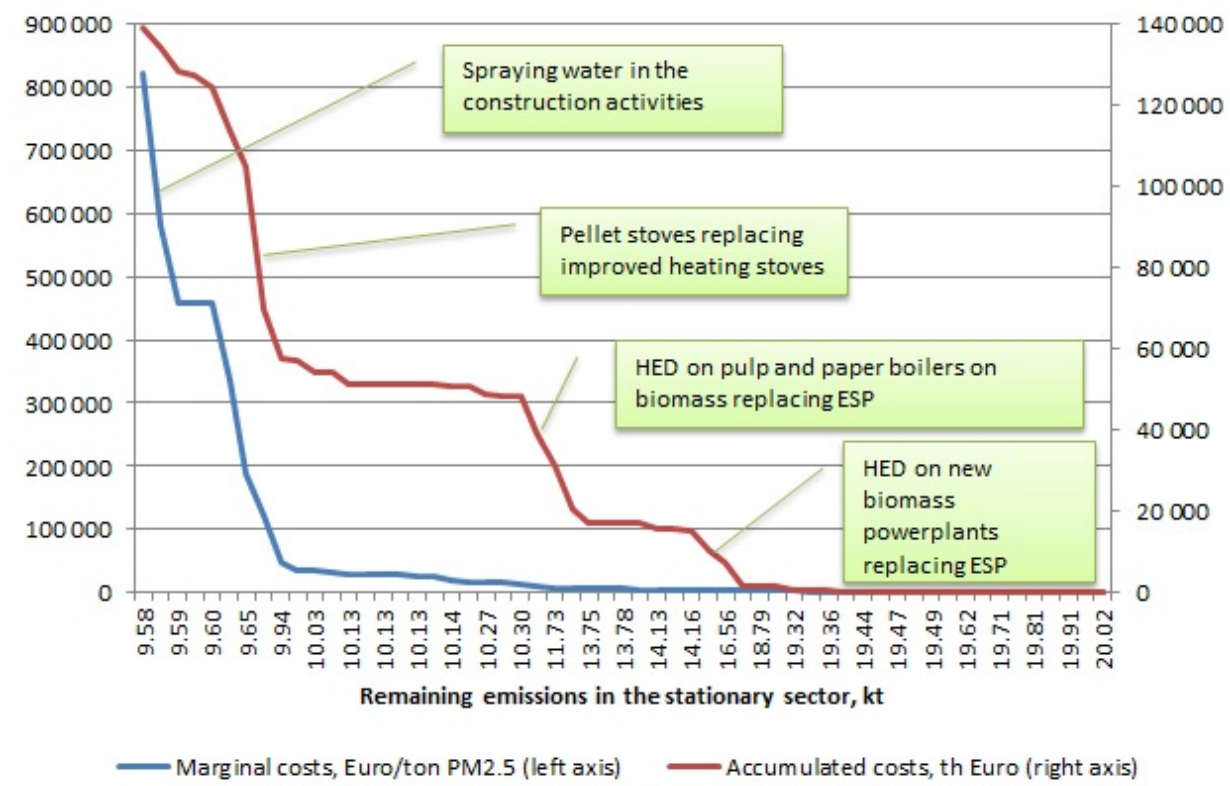

In this study we have only focused on the particle abatement measures available in the GAINS model database - these are mostly well-proven technical measures available on the market today. It is important to remember that this is not the full range of measures available in 2030: for example, fuel shifts and behavioural changes are excluded from 
the present analysis. A good summary of relevant abatement measures for black carbon is presented in Kindbom et al. 2018, where many of the non-technical measures are considered.

\subsection{Gap closure in the stationary sector - possible ambition levels for policy decisions}

Figure 30 presents modelled emissions of $\mathrm{PM}_{2.5}$ and black carbon in the Nordic countries for different emission reduction ambition levels in 2030. Similar as for Belarus, the BC curves are flatter than the $\mathrm{PM}_{2.5}$ curves for Low and Mid ambition levels, reflecting the situation when the most cost-effective abatement measures for $\mathbf{P M}_{2.5}$ do not significantly reduce $B C$ emissions.

Figure 30: Emissions of $\mathrm{PM}_{2.5}$ and $\mathrm{BC}$ from stationary sources corresponding to different levels of emission reduction ambitions in the Nordic countries, ktonnes
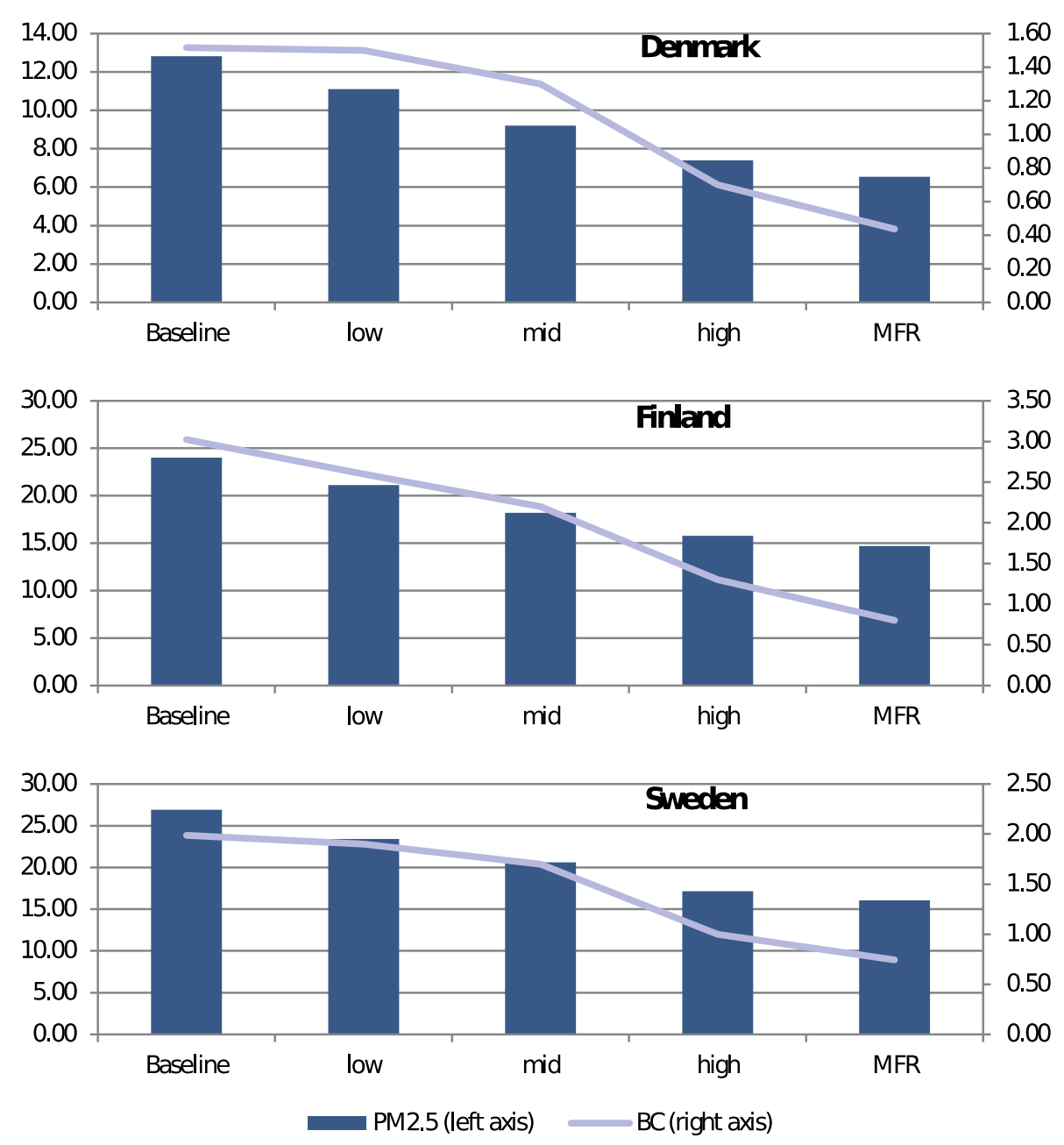


\subsection{Cost-benefit analysis}

Costs and benefits for the Nordic countries are estimated in the same way as described in Chapter 4.4. Figure 31 displays the results where only "internal" benefits (benefits within the same country) are considered.

Figure 31: Costs and benefits at different ambition levels of $\mathrm{PM}_{2.5}$ emission reductions in the Nordic countries
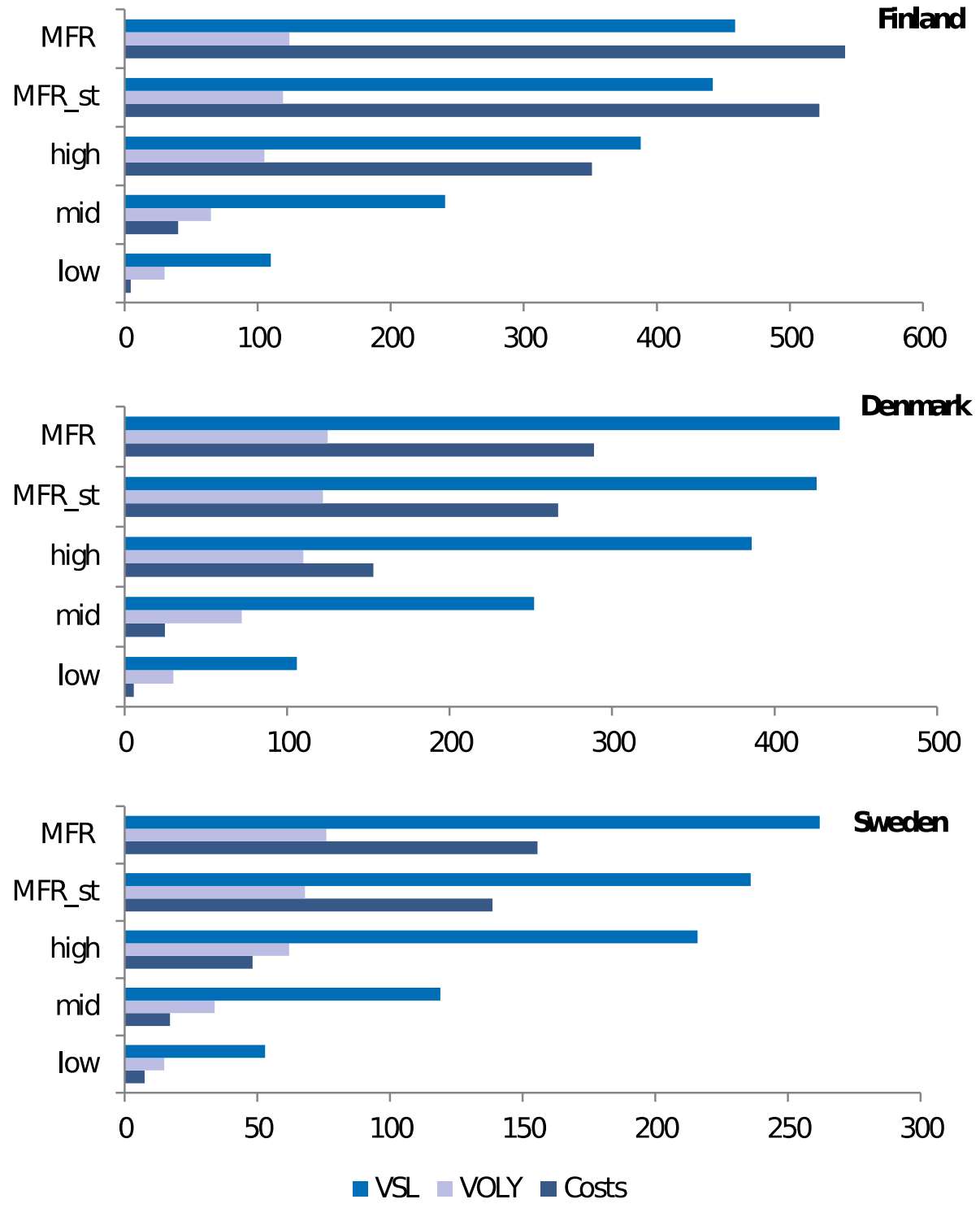

If the in-country benefits are valued in VOLY, they become equal to the costs on the ambition level between Mid and High for Denmark and Finland. In Sweden, the breakeven point is located above the High ambition level. VSL metric for valuation results in benefits overweighting costs in all cases, except for two MFR scenarios for Finland (with and without transport measures).

The results regarding the aggregated Nordic countries' costs and benefits for the whole European population are shown in Table 9. 
Table 9: CBA results for scenarios corresponding to different ambition levels regarding $\mathrm{PM}_{2.5}$ emission reductions in the three considered Nordic countries

\begin{tabular}{|c|c|c|c|c|c|c|c|}
\hline \multirow{2}{*}{$\begin{array}{l}\text { Emission reduction } \\
\text { ambition level }\end{array}$} & \multirow{2}{*}{$\begin{array}{r}\text { Costs }(3 \\
\text { countries) }\end{array}$} & \multicolumn{2}{|c|}{ Brutto benefits } & \multicolumn{2}{|c|}{ Net benefits } & \multicolumn{2}{|c|}{ Benefit-to-cost ratio } \\
\hline & & VOLY & VSL & VOLY & VSL & VOLY & VSL \\
\hline Low & 18 & 84 & 301 & 66 & 283 & 4.7 & 4.0 \\
\hline Mid & 82 & 201 & 717 & 119 & 635 & 2.4 & 4.2 \\
\hline High & 553 & 321 & 1150 & -232 & 597 & 0.6 & 4.2 \\
\hline MFR_st & 928 & 356 & 1270 & -572 & 342 & 0.4 & 4.1 \\
\hline MFR & 986 & 379 & 1354 & -607 & 368 & 0.4 & 4.2 \\
\hline
\end{tabular}

Note: Benefits in the whole Europe are included. Costs and benefits are expressed in million EUR.

The presented results indicate that reducing particle emissions in the Nordic countries would be cost-effective in terms of health benefits overweighting abatement costs even at the very high level of ambition, if the health effects in the whole of Europe are included in the analysis and VSL is used as a valuation metric. With the VOLY approach, Low and Mid ambition levels are still cost-effective while at High ambition levels costs become higher than considered health benefits.

\subsection{Transboundary effects from the implementation of MFR scenarios}

To estimate effects of transboundary pollution in Belarus, the Nordic countries and other European countries, we made model runs applying MFR scenarios for each country (Belarus, Denmark, Finland and Sweden) one by one, while for the rest of the countries we assume baseline development. Besides, we ran a scenario assuming that all three Nordic countries reduce their emissions to the MFR level, and another assuming that both the Nordic countries and Belarus apply MFR. For these six scenarios, we calculate changes in the population-weighted $\mathrm{PM}_{2.5}$ concentrations and related changes in average life expectancy (years of life gained as a result of better air quality). Furthermore, we estimate monetary values of this changes (health benefits) in VOLY and VSL.

The results of this analysis are presented in Appendix 10 and give an indication of how emissions decrease in one country or a group of countries from the expected baseline level to the lowest possible level in 2030 would affect people's health within the country itself and in other countries. For almost all considered country-to-country combinations, there are noticeable transboundary effects according to the modelling results - in other words, particle emissions in each of the considered countries affect population health in nearly all the other countries. Only for Belarus-to-Denmark and Finland-to-Denmark combinations, the changes in $\mathrm{PM}_{2.5}$ concentrations are, if any, too small to be captured by the GAINS model.

Reductions of particle emissions in the Nordic countries would mostly be noticeable within the countries and in certain neighbouring countries - but not that much in the rest of Europe. Reductions in Belarus would affect population health in other European countries (mostly Russia, Ukraine and Poland) almost as much as the country's own population. 


\subsection{Alternative BC emission factor datasets for heating stoves in the Nordic countries}

Both emission inventories (Kindbom et al. 2015) and GAINS modelling results (Chapter 5.1) indicate that heating stoves are one of the key sources of black carbon emissions in the Nordic countries. To explore the emission estimates' sensitivity to the choice of emission factors, we have run emission simulations using a set of alternative (based on the EMEP/EEA Guidebook) emission factors - in the way as described in Chapter 3.5.2. Current and alternative emission factors for $\mathrm{BC}$ in the Nordic countries are summarized in Annex 7.

Figure 32 illustrates the results of the model simulations with the two different emission factor sets. For Denmark, baseline emissions calculated with current emission factors are $41 \%$ higher than emissions based on alternative emission factors, while for Sweden and Finland the alternative emission factors result in 2-3\% higher emissions. This is because estimated emission factors for dominating categories in the baseline scenario - improved and new stoves (see Annex 7) - are higher than emission factors for the relevant stove categories in the GAINS model - for Sweden and Finland but not for Denmark. Figure 32: BC emissions from heating stoves in the Nordic countries in 2030, modelled with different
emission factor sets

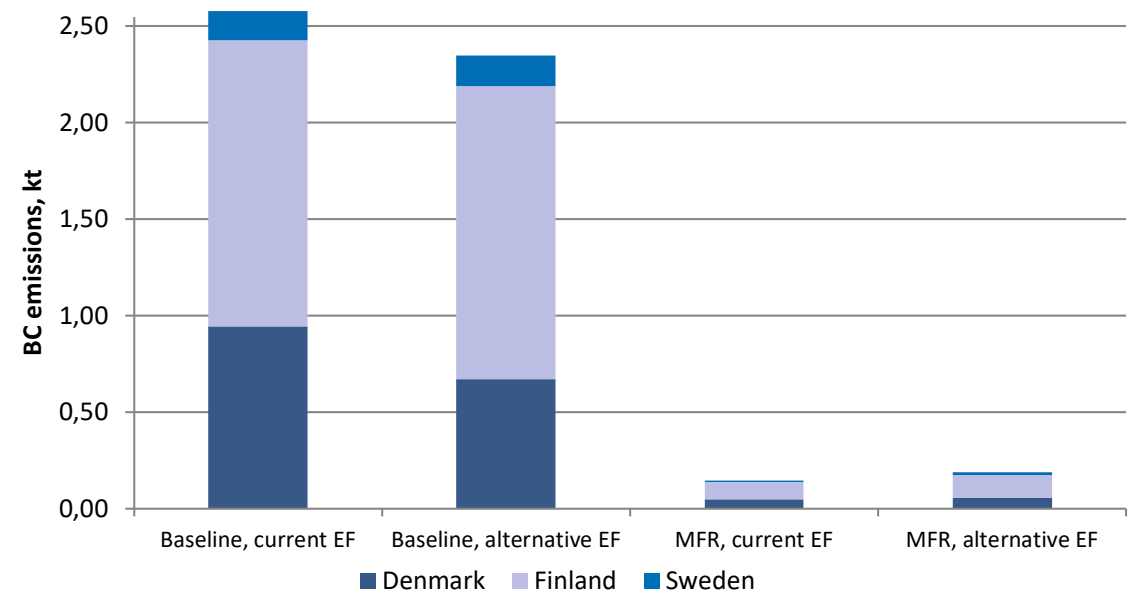

In the MFR scenario, applying the alternative emission factors results in higher emissions than applying the current emission factors - by $11-58 \%$. This is because the dominating stove categories in this scenario are pellet stove and pellet stove with ESP - and for the latter alternative emission factors are $7-57 \%$ higher than current emission factor, for all the Nordic countries.

Table 10 shows how the choice of emission factors affects emission reduction potentials and the shares of emissions from heating stoves in the total national BC emissions. For Denmark, emission reduction potentials are $46 \%$ higher if calculated with the current emission factors than if calculated with the alternative emission factors; for Finland and Sweden, the emission reduction potentials calculated with different emission factor sets are the same. The share of $\mathrm{BC}$ emissions from heating stoves in the national total emissions is not significantly affected for Finland ( $\sim 50 \%)$ and Sweden ( 8\%) while for Denmark it decreases from $62 \%$ to $54 \%$ when using alternative emission factors. 
Table 10: Heating stoves and alternative emission factors

\begin{tabular}{|c|c|c|c|c|}
\hline Parameter & EF set & Denmark & Finland & Sweden \\
\hline \multirow{2}{*}{$\begin{array}{l}\mathrm{BC} \text { from heating stoves, share in } \\
\text { national totals, baseline }\end{array}$} & Current EF & $62 \%$ & $49 \%$ & $7.8 \%$ \\
\hline & Alternative EF & $54 \%$ & $50 \%$ & $7.9 \%$ \\
\hline \multirow[t]{2}{*}{$\mathrm{BC}$ emission reduction potential, $\mathrm{kt}$} & Current EF & 0.89 & 1.40 & 0.14 \\
\hline & Alternative EF & 0.61 & 1.40 & 0.14 \\
\hline
\end{tabular}

The choice of emission factors used for emission simulations and for assessment of the emission reduction potentials is essential. Technology-based emission factors are to prefer, both in the modelling and in the compilation of the emission inventories. Emission simulations for the two considered cases (current GAINS model emission factors and the EMEP/EEA Guidebook-based emission factors) can be complemented by other possible emission factors sets - in particular, recently developed emission factors for heating stoves presented in Kindbom et al. 2017, or by national emission factors. Harmonization of the technology-specific emission factors used in the EMEP/EEA Guidebook and in the GAINS model should be continued and further developed; both sources require regular updates based on the latest measurement results.

\section{7 $\quad \mathrm{PM}_{2.5}$ and $\mathrm{BC}$ integrated assessment for the Nordic countries - conclusions}

The results of the integrated assessment modelling focused on $\mathrm{PM}_{2.5}$ and $\mathrm{BC}$ emissions in the Nordic countries show the very similar sectoral distribution of both particle fractions to the distribution as in the national inventories and projections (see Figure 12). According to the national emission inventories, the largest contributors to the emissions of black carbon in the Nordic countries in 2015 are residential combustion and road transport (in Sweden, it is estimated that about one-third of the emissions also comes from the energy sector). By 2030, the share of emissions from road transport will significantly decrease, according to the national emission projections. The sectoral structure of $\mathrm{PM}_{2.5}$ emissions is expected to be relatively constant between 2015 and 2030. In addition to residential combustion, the energy sector and road transport, some other sectors make significant contributions to the total $\mathrm{PM}_{2.5}$ emissions - industrial processes (especially pronounced in Sweden and Finland), and a combined category comprising agriculture, waste and product use (in Finland, this category contributes more than industrial processes).

The GAINS modelling results for the baseline emissions in 2030 show that the relative input of residential combustion into $\mathrm{PM}_{2.5}$ and $\mathrm{BC}$ emissions is significant - it is the largest contributor to emissions of both fractions, except for $\mathrm{PM}_{2.5}$ emissions in Sweden. Diesel vehicles are the second largest contributor to black carbon emissions in all three countries. The contribution from power plants to black carbon emissions is insignificant for Denmark and Finland, but clearly visible for Sweden, which correlates well with the emissions according to the national projections (Kindbom et al. 2018). Sectoral distribution of black carbon baseline emissions in the Nordic countries is very similar to the distribution in Belarus: the dominating source is residential combustion 
and the second largest source is transport. For $\mathrm{PM}_{2.5}$ emissions, the distribution is different: industrial process emissions are not that important in the Nordic countries while in Belarus it is the largest emission source accounting for almost half of the baseline emissions in 2030.

Estimated emission reduction potentials in 2030 (based on the ECLIPSE scenarios) are largest in the same sectors where emissions are high - mainly residential combustion, industrial combustion and power plants. Modelling indicates that the $\mathrm{PM}_{2.5}$ emission reduction potential in the energy sector is significant in Finland and Sweden, while emissions from industrial processes in Sweden (in particular, in the iron and steel industry and pulp and paper industry) remain the same in MFR - and thus do not contribute to the emission reduction potential. Regarding black carbon emissions 60 to $99 \%$ of the emission reduction potential is attributable to the residential combustion sector. In total, in the three considered countries, emissions of $\mathrm{PM}_{2.5}$ may be reduced by 26.3 ktonnes in 2030 , compared to the baseline level. For black carbon, the corresponding number is 4.5 ktonnes.

The cost-benefit analysis shows that the full implementation of MFR in the three Nordic countries in 2030 would require technical costs of EUR 990 million and result in societal benefits of EUR 330 (VOLY approach) to 1,200 (VSL approach) million, mainly attributable to reduced premature mortality in the European population due to reduced exposure to $\mathrm{PM}_{2.5}$. Expressed in VSL, the benefits are higher than costs at all considered ambition levels of the "gap closure" between the baseline and MFR scenarios. The VOLY approach would result in the break-even point located between Medium and High levels of ambition, meaning that abatement measures are cost-effective at least up to the Medium level. Health benefits mostly occur in the Nordic countries $-85-90 \%$ of the total estimated benefits in Europe.

Analysis of the transboundary pollution from particle emissions has been conducted by consequently reducing emissions in each country down to the MFR level and documenting relevant changes in the concentrations of particles and corresponding health effects in the four considered countries (Sweden, Denmark, Finland and Belarus). Emission reductions result in decreased negative health impacts in all the considered cases except for Belarus-to-Denmark and Finland-to-Denmark combinations. According to the modelling results, the reductions of particle emissions in the Nordic countries would mostly affect population within the countries and in certain neighbouring countries - but not that much in the rest of Europe. Reductions in Belarus, on the other hand, would improve population's health in other European countries (mostly Russia, Ukraine and Poland) almost as much as the health of the country's own population. 



\section{Discussion and conclusions}

Within the present study, a comprehensive analysis of $\mathrm{PM}_{2.5}$ and black carbon emissions in Belarus and in the three involved Nordic countries has been conducted. Main results comprise the improved emission inventory of $\mathrm{PM}_{2.5}$ and the first $\mathrm{BC}$ emission inventory in Belarus, analysis of emission reduction potentials, cost-effective emission reduction measures, costs and benefits for different reduction ambition levels, as well as emission simulations with alternative emission factors for certain sectors. In addition, a similar analysis (with the slightly lower level of ambition) has been done for the three Nordic countries - Denmark, Finland and Sweden. Analysis of the transboundary effects includes all four countries.

In order to compile the first black carbon emission inventory, the inventory of $P M_{2.5}$ in Belarus has been revised and improved, to be more consistent with the methodology described in the EMEP/EEA Guidebook. Emissions from certain previously missing sectors (i.e. aviation, asphalt roofing, cremations) have been added, and a range of GAINS-based emission factors have been replaced by default emission factors from the EMEP/EEA Guidebook. The resulting total emissions in 2014 are now higher -33.4 ktonnes $\mathrm{PM}_{2.5}$, compared to 28.8 ktonnes $\mathrm{PM}_{2.5}$ as reported previously. In the updated sectoral distribution of emissions, the contribution from residential combustion (wood combustion mainly) has increased from about one third to more than a half of the total emissions.

The black carbon emission inventory in Belarus has been compiled in a similar way as in most Nordic countries - by applying default $B C / P M_{2.5}$ shares from the EMEP/EEA Guidebook to sector- and fuel-specific $\mathrm{PM}_{2.5}$ emissions. The total black carbon emissions in 2014 are estimated at 3.87 ktonnes; from this, about $35 \%$ originates from residential combustion, $26 \%$ - from road vehicles, and $25 \%$ - from non-road sources. In the fuel structure of black carbon emissions, wood and diesel are two clearly dominating sources. Black carbon emissions from industrial processes are attributable to the production of lime, NPK fertilizers, iron and steel industries as well as pulp and paper plants.

The baseline scenario for particle emissions in Belarus in 2030 - the starting point for integrated assessment modelling - shows similar results regarding the sectoral distribution of $\mathrm{BC}$ emissions as in the Nordic countries. Both in Belarus and in the three considered Nordic countries, residential combustion is a predominant source of black carbon emissions, followed by diesel-fuelled vehicles - this picture is consistent with what national emission inventories and projections show. For $\mathrm{PM}_{2.5}$, the contribution of different emission sources is more country-specific - for instance, industrial processes are a significant source in Sweden but not in the other two Nordic countries. The total baseline emissions of $\mathrm{BC}$ in Belarus are estimated at 3.6 ktonnes, and emissions of $\mathrm{PM}_{2.5}$ -52 ktonnes. For the three Nordic countries in total, the corresponding numbers are 6.5 ktonnes $\mathrm{BC}$ and 64 ktonnes $\mathrm{PM}_{2.5}$.

The total emission reduction potential in 2030 (emission difference between the baseline scenario and the maximum feasible reduction scenario - MFR) is estimated at 35.2 ktonnes $\mathrm{PM}_{2.5}$ and 2.5 ktonnes $\mathrm{BC}$ for Belarus. For the three Nordic countries in 
total, the corresponding numbers are 26.3 ktonnes $\mathrm{PM}_{2.5}$ and 4.5 ktonnes BC. In general, large emission reduction potentials are observed in sectors with the largest contribution to the total emissions, implying that mitigation efforts should be taken in the key emitting sectors.

To enable identification of cost-effective measures necessary to reach a certain emission reduction ambition level (or to assess the possible level of emission reductions within certain budget limitations), a cost curve for $\mathrm{PM}_{2.5}$ has been compiled for all four countries. For Belarus, a black carbon cost curve has been compiled as well. A cost curve lists all measures necessary to close the gap between the emission levels corresponding to the baseline and MFR scenarios, in the order of their cost-effectiveness, starting with the lowest marginal costs. The most cost-effective measures for $\mathrm{BC}$ emissions in Belarus are end-of-pipe solutions (electrostatic precipitators, high-efficiency dedusters) for industrial furnaces and residential boilers, as well as replacement of conventional boilers with improved devices. These measures result in significant black carbon emission reductions at relatively low costs. The cost curve for $\mathrm{PM}_{2.5}$ includes more measures than the $B C$ cost curve, and thus the total costs of the gap closure in the stationary sector in Belarus are different (EUR $\sim 655$ million for $\mathrm{PM}_{2.5}$ and EUR $\sim 560$ million for $B C$ ). At the same time, if one attempts to decrease $\mathrm{PM}_{2.5}$ emissions in Belarus to a certain level by following the $\mathrm{PM}_{2.5}$ cost curve, it would cost less than if the same attempt is made by following the $B C$ cost curve. This is because many less costly measures at the beginning of the $\mathrm{PM}_{2.5}$ cost curve can significantly reduce $\mathrm{PM}_{2.5}$ but are much less efficient for BC - for instance, installation of ESP at refineries and cement plants. In general, it is more cost-effective not to consider $\mathrm{BC}$ when reducing $\mathrm{PM}_{2.5}$ emissions - but if policy-makers would like to take this UNECE CLRTAP recommendation into consideration, the developed $B C$ cost curve can be used for this purpose.

Cost-effectiveness is an essential factor in decision-making, but sometimes it is easier to develop and implement sectoral emission reduction strategies than to develop proper instruments in order to implement several low-cost measures in different sectors. Sector-specific abatement costs have been briefly assessed for different ambition levels of emission reductions in Belarus - a deeper investigation of this aspect could be useful for further work.

Implementation of measures in the transport sector in Belarus would bring the additional 1.4 ktonnes reduced $\mathrm{PM}_{2.5}$ and 0.9 ktonnes reduced $\mathrm{BC}$, on top of the measures for the stationary sources. The total costs of abatement in this sector amount to EUR 450 million - always as high as costs of reducing emissions from the stationary sources only. Implied additional measures are more rapid vehicle turnover with the resulting large share of higher emission control stages - Euro $6 / \mathrm{VI}$ for road transport, stage 5 Control for diesel vehicles used in agriculture, and for trains. For the three Nordic countries, the emission reduction potentials in the transport sector are estimated at 0.9 ktonnes $\mathrm{PM}_{2.5}$ and 0.3 ktonnes $\mathrm{BC}$, at the additional cost of EUR 58 million. Introduction of emission control on traffic in the Nordic countries is mostly included in the baseline so that the remaining additional measures do not contribute a lot to the total emission reduction potentials.

Technical costs and societal benefits have been analysed for three possible ambition levels regarding the gap closure for stationary sources: Low (40\%), Medium $(60 \%)$, and High (90\%). MFR for all sources and MFR for stationary sources only (with 
baseline development assumed for transport) have been considered separately. The total (brutto) societal benefits from full implementation of the MFR scenario in Belarus are estimated at between EUR 600 (VOLY) and 2,100 (VSL) million, depending on the chosen valuation metric. About half of them are due to population health improvements in the neighbouring countries. For the three Nordic countries together, the total societal benefits from full implementation of the MFR scenario are estimated at EUR 330 (VOLY) -1,200 (VSL) million, with health improvements to 85-90\% attributable to the improvements in the Nordic population's health. In case VOLY is used as the main valuation metric, emission reductions in Belarus appear to be costeffective (in terms of in-country benefits exceeding costs) even at the High level of ambition. In the Nordic countries, the break-point lies below the High ambition level implying that most cost-effective abatement measures will be included in the baseline so that additional reductions to the same ambition level as in Belarus would result in higher costs. If benefits are valued in VSL, emission reductions even at the MFR level would be cost-effective for both Belarus (with the net benefit within the country at EUR 220 million) and two of the three Nordic countries - Denmark and Sweden. For Finland, using VSL would result in shifting the cost-effectiveness break-point to above the High emission reduction ambition level.

Analysis of the transboundary effects, performed by consequently reducing emissions down to the MFR level in each country, indicates that particle emissions in each of the considered countries affect population in the other countries, with the exception of Belarus-to-Denmark and Finland-to-Denmark combinations (there is either no effect or too small effect to be captured in the GAINS model). Reductions of particle emissions in the Nordic countries would mostly be noticeable within the countries and in certain neighbouring countries - but not that much in the rest of Europe. Reductions in Belarus would affect population in other European countries (mostly Russia, Ukraine and Poland) almost as much as the country's own population.

There are quite significant differences in the total emissions according to the national emission inventories and projections, and as obtained in the GAINS model baseline scenarios. For Belarus, the GAINS model tends to produce $\sim 40 \%$ higher emissions than the national inventories do. In order to investigate the effect of the emission factors on the emissions and emission reduction potentials, simulation runs with a set of alternative emission factors have been made. Chosen alternative emission factors are based on default emission factors as specified in the EMEP/EEA Guidebook - but presented per abatement technology. $\mathrm{PM}_{2.5}$ emissions from main industrial processes in Belarus and BC emissions from heating stoves in all four countries have been included in this analysis. The results show that for industrial processes in Belarus, sector-specific emissions of $\mathrm{PM}_{2.5}$ simulated with the alternative emission factors are 46-98\% lower than emissions obtained with the emission factors currently applied in the GAINS model. This concerns both baseline and MFR emissions so that the total resulting emission reduction potential for $\mathrm{PM}_{2.5}$ in the key industrial processes (production of secondary steel, cement, lime and fertilizers) is 15 ktonnes lower with alternative emission factors. Using the EMEP/EEA Guidebook-based emission factor set also puts industrial processes to the third place in the emission source ranking instead of the first place in case the conventional GAINS emission factors are used. As for $B C$ emissions from heating stoves in Belarus, the alternative emission factors also result in slightly (by $22 \%$ ) lower emissions in the baseline than in case the conventional 
GAINS emission factors are used - but these emission factor sets seem to be closer to each other than emission factor sets for industrial processes. For the Nordic countries, alternative emission factors for heating stoves can be higher or lower than conventional GAINS emission factors - that depends on the country-specific technological profile of appliances. Harmonization of the technology-specific emission factors used in the Guidebook and in the GAINS model should be continued and further developed; both sources require regular updates based on the latest measurement results.

The integrated assessment modelling in this study is conducted with the two models: GAINS and the ALPHA RiskPoll. Both are widely used within the UNECE CLRTAP and for the EU air quality policy - for estimating emission reduction potentials, costs and benefits at the European scale and for identification of the most costeffective measures that provide the highest benefit at the lowest cost across a number of countries. These two models are designed for analysis of cost-effectiveness on an aggregated (European) level and are essential as unified tools when it comes to providing a scientific basis for negotiations within international agreements. However, they are not always sufficient for air quality work at the country level and at more local levels (regions, cities) where a much more detailed level of analysis can and should be used. Besides, abatement measures explicitly considered in GAINS are almost exclusively technical measures such as process modifications, end-of-pipe solutions, or better housekeeping to avoid fugitives. For more comprehensive assessment of the emission reduction potential and relevant measures and instruments at the national and regional levels, other options (not explicitly included in the GAINS model measure database) should be considered. These are, for instance, substitution of fuels, development of infrastructure for less extensive and less emitting transport (bicycle lanes, charging stations for hybrid vehicles), as well as a range of measures and economic instruments targeting behavioural changes and investments made by industries - taxes, subsidies, economic schemes encouraging public transport, low emission zones and similar. To estimate the effects of such measures and to include them in the modelling is much more difficult and is not within the scope of the current project. They can, however, have a significant effect on emissions. It is sometimes also important exactly where the emissions are reduced on a country level (e.g. if the population is unevenly distributed within a country) - for this purpose dispersion modelling with high-resolution models, using gridded emissions as input, can be of great help.

The results of this study regarding the emission inventory part and the integrated assessment modelling part are presented separately. Discrepancies between the emission inventories and integrated modelling results are a common problem for many countries, and Belarus is not an exception. Since proper simulations of baseline emissions are the starting point for any further analysis (e.g. integrated assessment modelling), more efforts should be put into minimizing the discrepancies between these two data sets - in particular, into investigation of the reasons of observed discrepancies and into harmonization of the emissions at least at the level of the national totals. One of the main reasons for discrepancies in the case of $\mathrm{PM}_{2.5}$ emissions in Belarus is the rather large differences in the applied emission factors for key emitting sources - industrial processes. Other reasons are differences in activity data and some emission sources missing in the national inventories due to the lack of input data. Besides, there is an issue of recurrent recalculations of the whole time series of 
emissions in the emission inventories, while in the GAINS model input data and emissions for the past years are usually kept at the same level. There is a need for more efficient communication with IIASA on this issue, preferably with possibilities for bilateral consultations in a similar way as they are organized for EU countries. From the emission inventory side, there is a need for more thorough analysis of the default emission factors provided in the then EMEP/EEA Guidebook, in particular regarding abatement technologies behind them and their relevance for a particular country, as well as for the development of national emission factors based on the country-specific information. To develop this work, effective cooperation between emission inventory experts and branch experts is necessary.

The analysis in this study is focused strictly on the air quality perspective of the particle emissions. Climate impacts, such as the warming effect of black carbon, are not considered - for investigating measures that are beneficial for both climate and health, a more comprehensive analysis covering all short-lived climate pollutants should be conducted like it has been done within the ECLIPSE study (Stohl et al. 2015).

To summarize, the present report covers several important aspects of the integrated analysis of particle emissions in Belarus (and to a certain extent in the Nordic countries), and provides scientists and decision-makers in Belarus with the following results:

- An improved emission inventory of $\mathrm{PM}_{2.5}$ following the methodology specified in the EMEP/EEA Air Pollutant Emission Inventory Guidebook (2013);

- The first black carbon emission inventory in Belarus;

- Estimates of baseline emissions of $\mathrm{PM}_{2.5}$ and $\mathrm{BC}$ in 2030, emissions according to the maximum feasible emission reduction (MFR) scenario, and emission reduction potentials;

- Separate sets of the most cost-effective measures to reduce emissions of $\mathrm{PM}_{2.5}$ and $B C$ in Belarus - either to a desired level of emissions or within a specified budget - including detailed specification of each measure's emission reduction potential and marginal costs;

- Sector-specific and total technical costs for several ambition levels regarding potential emission reductions in a range between the baseline and the MFR emissions (a gap closure approach);

- Estimates of societal benefits and cost-effectiveness of implementation of emission reduction measures at different ambition levels;

- Analysis of transboundary pollution regarding particle emissions (populationweighted concentrations of $\mathrm{PM}_{2.5}$, related health effects and their valuations);

- Analysis of the impact of using alternative (based on the EMEP/EEA Guidebook) emission factors for certain key emitting sectors.

The results of this study can be used as a scientific basis for decision-making in the development of national strategies to reduce particle emissions in Belarus (and to a certain extent in the Nordic countries), and for negotiations within international agreements, such as the revised Gothenburg protocol under the UNECE CLRTAP. 



\section{References}

Amann, M., Bertok, I., Borken-Kleefeld, J., Cofala, J., Heyes, C., Höglund-Isaksson, L., Klimont, Z., Rafaj, P., Schöpp, W., and Wagner, F. (2011a). An updated set of cost-effective emission reductions for the revision of the Gothenburg Protocol: Background paper for the 49 th Session of the Working Group on Strategies and Review. Geneva, September 12-15, 2011, CIAM report 4/2011.

Amann, M., Bertok, I., Borken-Kleefeld, J., Cofala, J., Heyes, C., Höglund-Isaksson, L., Klimont, Z., Nguyen, B., Posch, M., Rafaj, P., Sandler, R., Schöpp, W., Wagner, F., and Winiwarter, W. (2011b). Cost-effective control of air quality and greenhouse gases in Europe: Modeling and policy applications. Environmental Modelling \& Software 26: 1489-1501.

Amann, M. et al. (2015). Adjusted historic emission data, projections, and optimized emission reduction targets for 2030 - A comparison with COM data 2013, Part A: Results for EU-28. TSAP report $16 \mathrm{~A}$.

Bosch, P., Coenen, P., Fridell, E., Åström, S., Palmer, T., and Holland, M. (2009). Cost Benefit Analysis to Support the Impact Assessment accompanying the revision of Directive 1999/32/EC on the Sulphur Content of certain Liquid Fuels. Harwell: AEA Technology plc.

Desaigues et al. (2011). Economic valuation of air pollution mortality: A 9-country contingent valuation survey of value of a life year (VOLY).

EMEP/EEA (2013). EMEP/EEA Air Pollutant Emission Inventory Guidebook http://www.eea.europa.eu/publications/emep-eea-guidebook-2013

Energy Potential Development Strategy of the Republic of Belarus (2010) (in Russian) http://pravo.newsby.org/belarus/postanovsm2/sovm955.htm

Holland, M., Wagner, A., Hurley, F., Miller, B and Hunt, A. (2011). Costs benefit analysis for the Revision of the National Emission Ceiling Directive: Policy options for revisions to the Gothenburg Protocol to the UNECE Convention on Long-Range Transboundary Air Pollution. Report to European Commission.

Holland, M., Pye, S., Jones, G., Hunt, A. and Markandya, A. (2013). The Alpha Benefit Assessment Model - EC4MACS Modelling Methodology.

Holland, M. (2014). Cost-Benefit Analysis of Final Policy Scenarios for the EU Clean Air Package.

Kakareka, S., Krukowskaya, O. (2011). Particulate matter air emission reduction potential in Belarus. Nature Management 20, 2011 (in Russian).

Kindbom, K., Fridell, E., Skårman, T., Nielsen, O.-K., Winther, M., Saarinen, K., Lappi, M., Lamberg, H., Kolka Jónsson, P.V., Aasestad, K. (2015). Improved emission inventories of SLCP: Background analysis. TemaNord 2015:523.

Kindbom, K., Mawdsley, I., Nielsen, O.-K., Saarinen, K., Jónsson, K., and Aasestad, K. (2017). Emission factors for SLCP emissions from residential wood combustion in the Nordic countries: Improved emission inventories of Short Lived Climate Pollutants (SLCP). TemaNord 2017:570.

Kindbom, K., Yaramenka, K., Helbig, T., Mawdsley, I., Nielsen, O.-K., Saarinen, K., Jónsson, K., and Aasestad, K (2018). Measures to reduce emissions of Short-Lived Climate Pollutants (SLCP) in the Nordic countries. TemaNord 2018:533.

Klimont, Z., Cofala, J., Bertok, I., Amann, M., Heyes, C., and Gyarfas, F. (2002). Modeling Particulate Emissions in Europe: A Framework to Estimate Reduction Potential and Control Costs. IIASA Interim Report. IIASA, Laxenburg, Austria: IR-02-076 http://pure.iiasa.ac.at/id/eprint/6712/1/IR-02-076.pdf

National Statistical Committee of the Republic of Belarus. Industry in the Republic of Belarus, Statistical book 2016 (in Russian) http://www.belstat.gov.by/ofitsialnayastatistika/publications/izdania/public_compilation/index_5412/

Purohit, P., Höglund-Isaksson, L. (2017). Global emissions of fluorinated greenhouse gases 2005-2050 with abatement potentials and costs. Atmos. Chem. Phys., 17, 2795-2816, doi:10.5194/acp-17-2795-2017 
Stohl et al. (2015). Evaluating the climate and air quality impacts of short-lived pollutants.

Atmos. Chem. Phys., 15, 10529-10566 https://doi.org/10.5194/acp-15-10529-2015

WHO (2012). Health effects of black carbon

http://www.euro.who.int/_data/assets/pdf_file/o004/162535/eg6541.pdf 


\section{Sammanfattning}

Syftet med detta projekt är att stimulera beslutsfattare i Belarus att i deras insatser för att reducera utsläpp av $\mathrm{PM}_{2.5}$ prioritera åtgärder riktade mot minskning av utsläpp av sot (black carbon, BC), som uppmanas i Göteborgsprotokollet under Luftvårdskonventionen (FN:s Ekonomiska Kommission för Europa, Konventionen om långväga gränsöverskridande luftföroreningar - UNECE (LRTAP). För att uppnå detta syfte samt för att bygga upp en vetenskaplig grund som behövs för vidareutveckling av nationella strategier, har vi utfört en omfattande analys av $B C$ utsläpp, utsläppsminskningspotentialer och kostnadseffektiva åtgärder i Belarus. I denna rapport sammanfattas analysresultaten.

I rapporten presenteras två huvuddelar av den utförda analysen: den ena är fokuserad på emissionsinventeringar och den andra sammanfattar resultaten av integrerad åtgärdsmodellering. Huvuddelen av analysen handlar om Belarus men en del resultat har producerats för de tre nordiska länderna involverade i projektet Danmark, Finland och Sverige. Åren 2014-2015 antas representera nuläget medan framtidsscenarier har utförts för året 2030.

Rapporten täcker flera viktiga aspekter av integrerad analys av partikelutsläpp i Belarus (och till viss mån även i de nordiska länderna) och förser vetenskapsmän samt beslutsfattare med följande resultat:

- En förbättrad $\mathrm{PM}_{2.5}$ emissionsinventering enligt metodologin specificerad $\mathrm{i}$ EMEP/EEA Air Pollutant Emission Inventory Guidebook (2013).

- Den första emissionsinventeringen av black carbon som gjort för Belarus.

- Uppskattningar av utsläpp av $\mathrm{PM}_{2.5}$ och BC enligt baslinje och enligt ett s.k. maximum feasible emission reduction (MFR) scenario, samt av potentialer för utsläppsminskningar.

- Listor över de mest kostnadseffektiva åtgärderna för att minska utsläpp av PM2.5 och BC - till en viss utsläppsnivå eller inom en viss budget - inklusive detaljerade specifikationer av varje åtgärds utsläppsminskningspotential och marginella kostnad.

- Sektorsspecifika och totala tekniska kostnader för flera ambitionsnivåer för potentiella utsläppsminskningar mellan baslinje-utsläpp och MFR-utsläpp (s.k. gap closure metod).

- Uppskattningar av samhällsnyttor och kostnadseffektivitet vid implementering av utsläppsminskningsåtgärder motsvarande de olika ambitionsnivåerna.

- Analys av gränsöverskridande luftföroreningar med partiklar (befolkningsviktade koncentrationer av $\mathrm{PM}_{2.5}$, relaterade hälsoeffekter samt monetära värderingar av dessa).

- Analys av påverkan av alternativa emissionsfaktorer (baserade på EMEP/EEA Guidebook) för vissa nyckelutsläppskällor. 
Enligt den förbättrade emissionsinventeringen uppgick utsläppen av $\mathrm{PM}_{2.5}$ i Belarus under 2014 till 33.4 kton. De totala nationella BC-utsläppen för samma år uppskattas till 3.87 kton, varav den största andelen kommer från småskalig vedeldning.

Med den integrerade åtgärdsmodelleringen uppskattas de totala nationella BCutsläppen i Belarus till 3.6 kton för året 2030 och PM $_{2.5}$-utsläppen till 52 kton för samma år. Totala utsläppsminskningspotentialer (skillnaden mellan utsläpp enligt bas-scenariot och utsläpp enligt scenariot med maximala möjliga utsläppsminskningen - MFR) uppskattas till 35.2 kton $\mathrm{PM}_{2.5}$ och 2.5 kton BC. Potentialer för utsläppsminskningar är högst i samma sektorer som bidrar mest till de nationella totalerna, vilket tyder på att åtgärder i första hand borde vidtas i nyckelsektorer.

Kostnadskurvor har byggts för $\mathrm{PM}_{2.5}$ och för BC. En kostnadskurva listar alla åtgärder som behövs för att komma från bas-scenariot till MFR-scenariot (to close the gap), rankade enligt kostnadseffektiviteten från lägsta marginella kostnader och uppåt. De mest kostnadseffektiva åtgärderna mot BC-utsläpp i Belarus är, enligt denna analys, "end-of-pipe" lösningar (såsom elektriska filter) för industriella ugnar och pannor i bostadssektorn samt ersättning av konventionella pannor med förbättrad utrustning. Dessa åtgärder kan resultera i betydande minskningar av BC-utsläpp med relativt låga kostnader.

Den totala (brutto) samhällsnyttan vid implementeringen av MFR-scenariot i Belarus uppskattas till mellan 600 (VOLY - Value of a Life Year lost) och 2100 (VSL Value of Statistical Life) miljoner EUR, beroende på val av värderingsmetodiken. Ungefär hälften av detta motsvarar negativa hälsoeffekter som undviks i grannländerna. Om VOLY används för värdering av nyttan verkar emissionsminskningar kostnadseffektiva ( $\mathrm{i}$ den meningen att nyttan $\mathrm{i}$ Belarus överskrider kostnader) på ambitionsnivån High - men inte för MFR. Om nyttan värderas i VSL är emissionsminskningarna kostnadseffektiva även för MFR-scenariot nettonyttan i landet utgör i detta fall 220 miljoner EUR. I värderingen av samhällsnyttan i denna studie har vi bara inkluderat hälsoeffekter.

Analysen av gränsöverskridande effekter, utförd genom konsekutiva minskningar av utsläpp ner till MFR-nivån, land för land, indikerar att partikelutsläpp i vart och ett av de fyra länderna påverkar befolkningshälsan i de andra länderna, förutom i fallen Belarus-till-Danmark samt Finland-till-Danmark. I dessa två fall finns antingen ingen påverkan eller är påverkan så liten att det inte kan tas med i GAINS-modellen. Minskningar av partikelutsläpp i Belarus påverkar befolkningens hälsa i grannländerna (i synnerhet Ryssland, Ukraina och Polen) nästan lika mycket som landets egen befolknings hälsa.

För att utforska hur olika emissionsfaktorer påverkar resulterande utsläpp samt utsläppsminskningspotentialer har vi simulerat modellberäkningar med en rad alternativa emissionsfaktorer (baserade på default värden i EMEP/EEA Guidebook) för nyckelsektorer. Användning av alternativa emissionsfaktorer för $\mathrm{PM}_{2.5}$ för Belarus resulterar i betydligt lägre utsläpp ( 21 kton) jämfört med beräkningarna utförda med GAINS-modellens nuvarande emissionsfaktorer.

Resultaten av denna studie kan användas som vetenskaplig grund för beslutsfattare i Belarus, vid utveckling av nationella strategier för att minska partikelutsläpp i landet, och i viss utsträckning även i de nordiska länderna. De kan även användas som grund vid förhandlingar inom internationella överenskommelser såsom Göteborgsprotokollet under Luftvårdskonventionen. 


\section{Annex 1. Emission factors used in the $\mathrm{PM}_{2.5}$ inventories in Belarus}

Table 11: Emission factors used in the $\mathrm{PM}_{2.5}$ inventories in Belarus

\begin{tabular}{|c|c|c|c|c|c|c|}
\hline \multirow[t]{2}{*}{ Code } & \multirow[t]{2}{*}{ Category } & \multirow[t]{2}{*}{ Fuel } & \multicolumn{2}{|c|}{$\begin{array}{l}\text { EF in the updated inventory } \\
\text { (EMEP/EEA Guidebook) }\end{array}$} & \multicolumn{2}{|c|}{$\begin{array}{l}\text { EF in the previous inventory } \\
\text { (GAINS-based or national) }\end{array}$} \\
\hline & & & Value & Unit & Value & Unit \\
\hline $1 \mathrm{~A} 1 \mathrm{a}$ & Public electricity and heat production & wood & 0.133 & $\mathrm{~kg} / \mathrm{PJ}$ & 0.145 & $\mathrm{~kg} / \mathrm{PJ}$ \\
\hline $1 \mathrm{~A} 1 \mathrm{a}$ & Public electricity and heat production & peat & 0.0032 & $\mathrm{~kg} / \mathrm{PJ}$ & 0.417 & $\mathrm{~kg} / \mathrm{PJ}$ \\
\hline $1 \mathrm{~A} 1 \mathrm{a}$ & Public electricity and heat production & mazut (heavy fuel oil) & 0.0193 & $\mathrm{~kg} / \mathrm{PJ}$ & 0.009 & $\mathrm{~kg} / \mathrm{PJ}$ \\
\hline $1 \mathrm{~A} 1 \mathrm{a}$ & Public electricity and heat production & natural gas & 0.00089 & $\mathrm{~kg} / \mathrm{PJ}$ & 0.00001 & $\mathrm{~kg} / \mathrm{PJ}$ \\
\hline $1 \mathrm{~A} 1 \mathrm{a}$ & Public electricity and heat production & associated gases oil extraction & 0.00089 & $\mathrm{~kg} / \mathrm{PJ}$ & - & \\
\hline $1 \mathrm{~A} 1 \mathrm{a}$ & Public electricity and heat production & 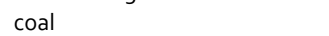 & 0.0034 & $\mathrm{~kg} / \mathrm{PJ}$ & 0.235 & $\mathrm{~kg} / \mathrm{PJ}$ \\
\hline $1 \mathrm{~A} 1 \mathrm{~b}$ & Petroleum refining & mazut (heavy fuel oil) & 0.009 & $\mathrm{~kg} / \mathrm{PJ}$ & - & \\
\hline $1 \mathrm{~A}_{4} \mathrm{ai}$ & Commercial/institutional: stationary & coal & 0.108 & $\mathrm{~kg} / \mathrm{PJ}$ & 0.156 & $\mathrm{~kg} / \mathrm{PJ}$ \\
\hline $1 \mathrm{~A} 4 \mathrm{ai}$ & Commercial/institutional: stationary & wood & 0.14 & $\mathrm{~kg} / \mathrm{PJ}$ & 0.206 & $\mathrm{~kg} / \mathrm{PJ}$ \\
\hline $1 \mathrm{~A} 4 \mathrm{ai}$ & Commercial/institutional: stationary & peat & 0.108 & $\mathrm{~kg} / \mathrm{PJ}$ & 0.063 & $\mathrm{~kg} / \mathrm{PJ}$ \\
\hline $1 \mathrm{~A}_{4} \mathrm{ai}$ & Commercial/institutional: stationary & mazut (heavy fuel oil) & 0.02 & $\mathrm{~kg} / \mathrm{PJ}$ & 0.010 & $\mathrm{~kg} / \mathrm{PJ}$ \\
\hline $1 \mathrm{~A} 4 \mathrm{ai}$ & Commercial/institutional: stationary & residential stove fuel & 0.0008 & $\mathrm{~kg} / \mathrm{PJ}$ & 0.0003 & $\mathrm{~kg} / \mathrm{PJ}$ \\
\hline $1 \mathrm{~A} 4 \mathrm{ai}$ & Commercial/institutional: stationary & natural gas & 0.00078 & $\mathrm{~kg} / \mathrm{PJ}$ & 0.0001 & $\mathrm{~kg} / \mathrm{PJ}$ \\
\hline $1 \mathrm{~A} 4 \mathrm{ai}$ & Commercial/institutional: stationary & liquefied gas & 0.00078 & $\mathrm{~kg} / \mathrm{PJ}$ & 0.0002 & $\mathrm{~kg} / \mathrm{PJ}$ \\
\hline $1 \mathrm{~A} 4 \mathrm{ai}$ & Commercial/institutional: stationary & refinery gases & 0.00078 & $\mathrm{~kg} / \mathrm{PJ}$ & 0.0001 & $\mathrm{~kg} / \mathrm{PJ}$ \\
\hline $1 \mathrm{~A} 4 \mathrm{ai}$ & Commercial/institutional: stationary & associated gases oil extraction & 0.00078 & $\mathrm{~kg} / \mathrm{PJ}$ & 0.0001 & $\mathrm{~kg} / \mathrm{PJ}$ \\
\hline $1 \mathrm{~A} 4 \mathrm{bi}$ & Residential: stationary & coal & 0.398 & $\mathrm{~kg} / \mathrm{PJ}$ & $0.32-0.4$ & $\mathrm{~kg} / \mathrm{PJ}$ \\
\hline $1 \mathrm{~A} 4 \mathrm{bi}$ & Residential: stationary & wood & 0.74 & $\mathrm{~kg} / \mathrm{PJ}$ & $0.186-0.233$ & $\mathrm{~kg} / \mathrm{PJ}$ \\
\hline $1 \mathrm{~A} 4 \mathrm{bi}$ & Residential: stationary & peat & 0.398 & $\mathrm{~kg} / \mathrm{PJ}$ & 0.240 & $\mathrm{~kg} / \mathrm{PJ}$ \\
\hline $1 \mathrm{~A} 4 \mathrm{bi}$ & Residential: stationary & natural gas & 0.0012 & $\mathrm{~kg} / \mathrm{PJ}$ & 0.0001 & $\mathrm{~kg} / \mathrm{PJ}$ \\
\hline $1 \mathrm{~A} 4 \mathrm{bi}$ & Residential: stationary & liquefied gas & 0.0012 & $\mathrm{~kg} / \mathrm{PJ}$ & 0.0003 & $\mathrm{~kg} / \mathrm{PJ}$ \\
\hline $1 \mathrm{~A} 4 \mathrm{bi}$ & Residential: stationary & associated gases oil extraction & 0.0012 & $\mathrm{~kg} / \mathrm{PJ}$ & 0.0001 & $\mathrm{~kg} / \mathrm{PJ}$ \\
\hline $1 \mathrm{~A} 2 \mathrm{a}$ & Stationary combustion in manufacturing industries and construction & coal & 0.108 & $\mathrm{~kg} / \mathrm{PJ}$ & 0.102 & $\mathrm{~kg} / \mathrm{PJ}$ \\
\hline $1 \mathrm{~A} 2 \mathrm{a}$ & Stationary combustion in manufacturing industries and construction & wood & 0.14 & $\mathrm{~kg} / \mathrm{PJ}$ & 0.145 & $\mathrm{~kg} / \mathrm{PJ}$ \\
\hline $1 \mathrm{~A} 2 \mathrm{a}$ & Stationary combustion in manufacturing industries and construction & peat & 0.108 & $\mathrm{~kg} / \mathrm{PJ}$ & 0.167 & $\mathrm{~kg} / \mathrm{PJ}$ \\
\hline $1 \mathrm{~A} 2 \mathrm{a}$ & Stationary combustion in manufacturing industries and construction & residential stove fuel & 0.02 & $\mathrm{~kg} / \mathrm{PJ}$ & 0.0003 & $\mathrm{~kg} / \mathrm{PJ}$ \\
\hline $1 \mathrm{~A} 2 \mathrm{a}$ & Stationary combustion in manufacturing industries and construction & other oil products & 0.02 & $\mathrm{~kg} / \mathrm{PJ}$ & & \\
\hline $1 \mathrm{~A} 2 \mathrm{a}$ & Stationary combustion in manufacturing industries and construction & natural gas & 0.00078 & $\mathrm{~kg} / \mathrm{PJ}$ & 0.0001 & $\mathrm{~kg} / \mathrm{PJ}$ \\
\hline $1 \mathrm{~A} 2 \mathrm{a}$ & Stationary combustion in manufacturing industries and construction & liquefied gas & 0.00078 & $\mathrm{~kg} / \mathrm{PJ}$ & 0.0002 & $\mathrm{~kg} / \mathrm{PJ}$ \\
\hline $1 \mathrm{~A} 2 \mathrm{a}$ & Stationary combustion in manufacturing industries and construction & refinery gases & 0.00078 & $\mathrm{~kg} / \mathrm{PJ}$ & 0.0001 & $\mathrm{~kg} / \mathrm{PJ}$ \\
\hline $1 \mathrm{~A} 2 \mathrm{a}$ & Stationary combustion in manufacturing industries and construction & associated gases oil extraction & 0.00078 & $\mathrm{~kg} / \mathrm{PJ}$ & 0.0001 & $\mathrm{~kg} / \mathrm{PJ}$ \\
\hline $2 \mathrm{~B} 10 \mathrm{a}$ & Chemical industry: Other: Production of NPK fertilizers & process & 0.18 & $\mathrm{~kg} / \mathrm{t}$ & 0.72 & $\mathrm{~kg} / \mathrm{t}$ \\
\hline
\end{tabular}




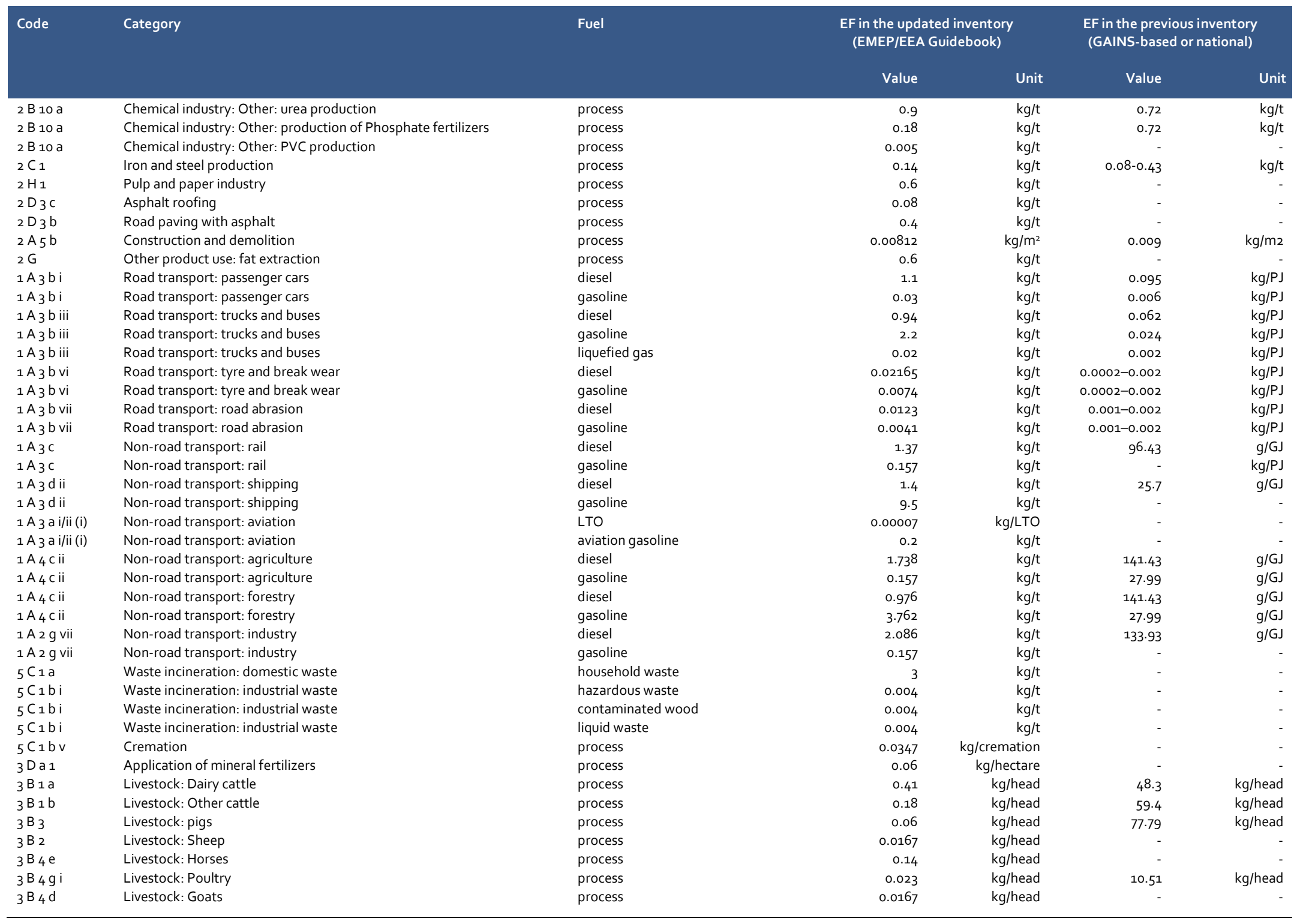




\section{Annex 2. National statistic on TSP emissions in Belarus in 2014}

Table 12: TSP emissions in Belarus in 2014 according to statistical data

$$
\text { Sector }
$$

Manufacturing industry

Production and distribution of electrical power, gas and water

Construction

Mobile sources

Note: Note that "Industry" here includes both energy-related (combustion) and process-related emissions.

Figur 33: TSP emissions in Belarus in 2014: sectoral distribution
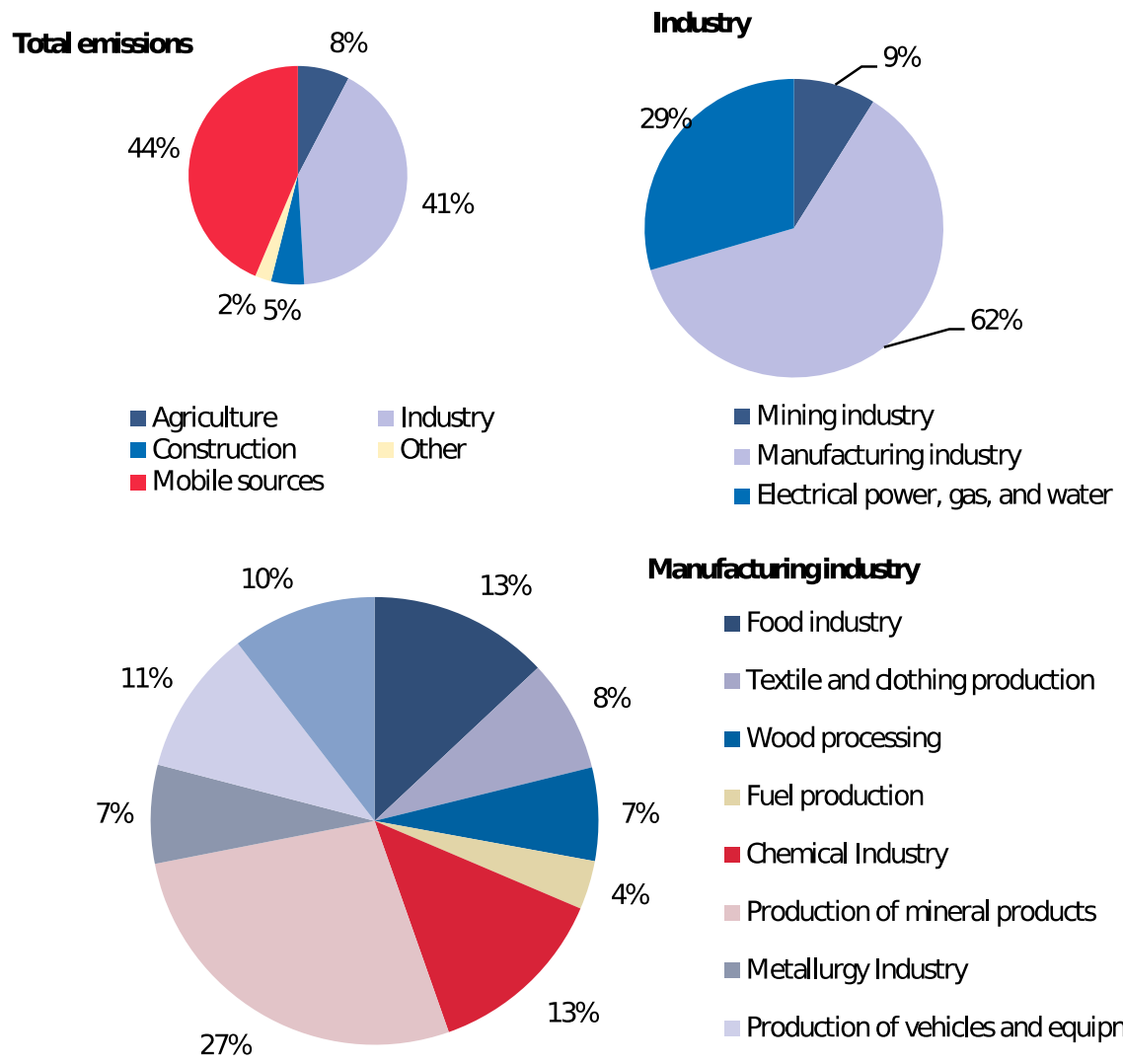

Manufacturingindustry

- Food industry

- Textile and clothing production

- Wood processing

Fuel production

n Chemical Industry

Production of mineral products

- Metallurgy Industry

Production of vehicles and equipment

- Other industries 



\title{
Annex 3. National guidelines for calculation of soot emissions
}

\author{
Soot emission inventory methodological basis in Belarus
}

Energy:

- TKP 17.08-01-2006 Environmental protection and management. Atmosphere. Emissions to the atmosphere. Emissions from boilers with a capacity up to 25 MW;

- TKP 17.08-04-2006 Environmental protection and management. Atmosphere. Emissions to the atmosphere. Emissions from boilers with capacity over $25 \mathrm{MW}$;

- Methods for assessment of emissions from stationary diesel sources (2001).

Industry:

- TKP 17.08-16-2011 Environmental protection and management. Atmosphere. Emissions to the atmosphere. Emissions from petrochemical enterprises.

Transport:

- TKP 17.08-12-2008 Environmental protection and management. Atmosphere. Emissions to the atmosphere. Emissions from railways.

Other:

- TKP 17.08-16-2011 Environmental protection and management. Atmosphere. Emissions to the atmosphere. Emissions from fires.

Table 13: Soot emissions subject to reporting

\begin{tabular}{lrl} 
Sector & $\begin{array}{c}\text { Number of } \\
\text { guidelines }\end{array}$ & Emission sources \\
\hline Stationary fuel combustion & 3 & Boilers (residual oil combustion) \\
& 1 & Stationary diesel installations \\
Petrochemical industry & 1 & Flaring, process furnaces \\
Metal industry and machine construction & 2 & Blacksmith forges, heating furnaces, drying chambers, \\
Fires & 1 & forging furnaces, etc. \\
Mobiles sources & 1 & $\begin{array}{l}\text { Forest fires, peat bog fires, agricultural waste burning, } \\
\text { burning of liquid petroleum products, etc. }\end{array}$ \\
& 1 & Road traffic - stock
\end{tabular}





\section{Annex 4. $\mathrm{PM}_{2.5}$ cost curves for stationary emission sources - specification of measures}

Measures below illustrate the cost curve approach to choosing the most cost-effective measures for a certain ambition level regarding PM 2.5 emission reductions. Measures should be applied in a given order, replacing already applied less efficient measures, until the target emission level ("remaining emissions") is achieved.

\begin{tabular}{|c|c|c|c|c|c|c|c|}
\hline Sector & Fuel & Abatement & $\begin{array}{r}\text { Replacing (\% of activity } \\
\text { data) }\end{array}$ & $\begin{array}{r}\text { Unit cost, } \\
\text { EUR/t } \mathrm{PM}_{2.5}\end{array}$ & $\begin{array}{r}\text { Marginal cost, } \\
\text { EUR/t PM }\end{array}$ & $\begin{array}{r}\text { Remaining } \\
\text { emissions, kt }\end{array}$ & $\begin{array}{r}\text { Accumulated costs, } \\
\text { th EUR }\end{array}$ \\
\hline Cement production & No fuel use & Electrostatic precipitator: 1 field & $0.81 \%$ cyclone & 45 & 14 & 50.35 & 16 \\
\hline Fertilizer production & No fuel use & High efficiency deduster & $7 \%$ cyclone & 29 & 25 & 36.61 & 355 \\
\hline $\begin{array}{l}\text { Glass production (flat, blown, container } \\
\text { glass) }\end{array}$ & No fuel use & Electrostatic precipitator: 1 field & $50 \%$ cyclone & 236 & 177 & 36.37 & 398 \\
\hline $\begin{array}{l}\text { Power \& district heat plants - existing } \\
\text { coal ( }<50 \text { MWth) }\end{array}$ & $\begin{array}{l}\text { Brown coal/lignite grade } 2 \\
\text { (also peat) }\end{array}$ & Electrostatic precipitator: 1 field & $40 \%$ cyclone & 386 & 214 & 36.12 & 452 \\
\hline $\begin{array}{l}\text { Glass production (flat, blown, container } \\
\text { glass) }\end{array}$ & No fuel use & Electrostatic precipitator: 1 field & $10 \%$ No control & 236 & 236 & 36.05 & 469 \\
\hline Cement production & No fuel use & Electrostatic precipitator: 2 fields & $0.81 \% \mathrm{ESP}_{1}$ & 53 & 308 & 35.99 & 485 \\
\hline Refineries & No fuel use & Electrostatic precipitator: 1 field & $70 \%$ cyclone & 510 & 332 & 34.54 & 966 \\
\hline $\begin{array}{l}\text { Power \& district heat plants - existing } \\
\text { (excl. coal) }\end{array}$ & Biomass fuels & Electrostatic precipitator: 1 field & $40 \%$ cyclone & 708 & 526 & 34.42 & 1,030 \\
\hline Medium boilers ( $<50 \mathrm{MW})$ - automatic & $\begin{array}{l}\text { Brown coal/lignite grade } 2 \\
\text { (also peat) }\end{array}$ & High efficiency deduster & $90 \%$ No control & 654 & 654 & 33.90 & 1,371 \\
\hline Industry: Other combustion, pulverized & $\begin{array}{l}\text { Brown coal/lignite grade } 2 \\
\text { (also peat) }\end{array}$ & High efficiency deduster & $10 \% \mathrm{ESP}_{2}$ & 388 & 771 & 33.88 & 1,387 \\
\hline Industry: Other combustion, pulverized & $\begin{array}{l}\text { Brown coal/lignite grade } 2 \\
\text { (also peat) }\end{array}$ & High efficiency deduster & $80 \% \mathrm{ESP}_{1}$ & 388 & 872 & 33.55 & 1,678 \\
\hline
\end{tabular}




\begin{tabular}{|c|c|c|c|c|c|c|c|}
\hline Sector & Fuel & Abatement & $\begin{array}{r}\text { Replacing (\% of activity } \\
\text { data) }\end{array}$ & $\begin{array}{l}\text { Unit cost, } \\
\text { EUR/t PM } 2.5\end{array}$ & $\begin{array}{r}\text { Marginal cost, } \\
\text { EUR/t PM }\end{array}$ & $\begin{array}{r}\text { Remaining } \\
\text { emissions, kt }\end{array}$ & $\begin{array}{r}\text { Accumulated costs, } \\
\text { th EUR }\end{array}$ \\
\hline Medium boilers $(<50 M W)$ - automatic & Hard coal, grade 1 & High efficiency deduster & $90 \%$ No control & 881 & 881 & 33.55 & 1,678 \\
\hline Industrial furnaces & Biomass fuels & Electrostatic precipitator: 1 field & $90 \%$ No control & 915 & 915 & 28.96 & 5,880 \\
\hline $\begin{array}{l}\text { Power \& district heat plants - existing } \\
\text { coal (<50 MWth) }\end{array}$ & $\begin{array}{l}\text { Brown coal/lignite grade } 2 \\
\text { (also peat) }\end{array}$ & High efficiency deduster & $80 \% \mathrm{ESP}_{1}$ & 447 & 995 & 28.90 & 5,931 \\
\hline $\begin{array}{l}\text { Production of glass fiber, gypsum, PVC, } \\
\text { other }\end{array}$ & No fuel use & Electrostatic precipitator: 1 field & $40 \%$ cyclone & 1,987 & 1,238 & 28.89 & 5,950 \\
\hline $\begin{array}{l}\text { Power \& district heat plants - existing } \\
\text { coal ( }<50 \mathrm{MW} \text { th) }\end{array}$ & $\begin{array}{l}\text { Brown coal/lignite grade } 2 \\
\text { (also peat) }\end{array}$ & High efficiency deduster & $10 \% \mathrm{ESP}_{2}$ & 447 & 1,319 & 28.88 & 5,955 \\
\hline $\begin{array}{l}\text { Glass production (flat, blown, container } \\
\text { glass) }\end{array}$ & No fuel use & High efficiency deduster & $90 \% \mathrm{ESP}_{1}$ & 312 & 1,481 & 28.84 & 6,017 \\
\hline $\begin{array}{l}\text { Glass production (flat, blown, container } \\
\text { glass) }\end{array}$ & No fuel use & Electrostatic precipitator: 2 fields & $10 \% \mathrm{ESP}_{1}$ & 278 & 1,560 & 28.84 & 6,021 \\
\hline Industry: Other combustion, pulverized & Hard coal, grade 1 & High efficiency deduster & $10 \% \mathrm{ESP}_{2}$ & 753 & 1,826 & 28.81 & 6,069 \\
\hline $\begin{array}{l}\text { Production of glass fiber, gypsum, PVC, } \\
\text { other }\end{array}$ & No fuel use & Electrostatic precipitator: 1 field & $1 \%$ No control & 1,987 & 1,987 & 28.81 & 6,070 \\
\hline Industry: Other combustion, pulverized & Hard coal, grade 1 & High efficiency deduster & $80 \% \mathrm{ESP}_{1}$ & 753 & 1,994 & 28.39 & 6,919 \\
\hline Cement production & No fuel use & High efficiency deduster & $6.24 \% \mathrm{ESP}_{2}$ & 123 & 2,365 & 27.97 & 7,904 \\
\hline Medium boilers ( $<1 \mathrm{MW})$ - manual & $\begin{array}{l}\text { Brown coal/lignite grade } 2 \\
\text { (also peat) }\end{array}$ & Cyclone & $90 \%$ No control & 2,821 & 2,821 & 27.81 & 8,350 \\
\hline Refineries & No fuel use & Electrostatic precipitator: 2 fields & $100 \% \mathrm{ESP}_{1}$ & 583 & 2,834 & 27.71 & 8,629 \\
\hline Refineries & No fuel use & High efficiency deduster & $90 \% \mathrm{ESP}_{2}$ & 669 & 3,427 & 27.63 & 8,933 \\
\hline Medium boilers ( $<1 \mathrm{MW})$ - manual & Hard coal, grade 1 & Cyclone & $90 \%$ No control & 3,886 & 3,886 & 27.63 & 8,933 \\
\hline $\begin{array}{l}\text { Power \& district heat plants - existing } \\
\text { (excl. coal) }\end{array}$ & Biomass fuels & High efficiency deduster & $10 \% \mathrm{ESP}_{2}$ & 953 & 3,973 & 27.62 & 8,940 \\
\hline Single house boilers $(<50 \mathrm{~kW})$ - manual & $\begin{array}{l}\text { Brown coal/lignite grade } 2 \\
\text { (also peat) }\end{array}$ & Coal single house boiler new & $90 \%$ No control & 4,106 & 4,106 & 27.45 & 9,638 \\
\hline Single house boilers $(<50 \mathrm{~kW})$ - manual & Hard coal, grade 1 & Coal single house boiler new & go No control & 4,308 & 4,308 & 27.45 & 9,645 \\
\hline
\end{tabular}




\begin{tabular}{|c|c|c|c|c|c|c|c|}
\hline Sector & Fuel & Abatement & $\begin{array}{r}\text { Replacing (\% of activity } \\
\text { data) }\end{array}$ & $\begin{array}{r}\text { Unit cost, } \\
\text { EUR/t PM } 2.5\end{array}$ & $\begin{array}{r}\text { Marginal cost, } \\
\mathrm{EUR} / \mathrm{t} \mathrm{PM}_{2,5}\end{array}$ & $\begin{array}{r}\text { Remaining } \\
\text { emissions, kt }\end{array}$ & $\begin{array}{r}\text { Accumulated costs, } \\
\text { th EUR }\end{array}$ \\
\hline $\begin{array}{l}\text { Power \& district heat plants - existing } \\
\text { (excl. coal) }\end{array}$ & Biomass fuels & High efficiency deduster & $80 \% \mathrm{ESP}_{1}$ & 953 & 4,459 & 27.43 & 9,755 \\
\hline Industrial furnaces & $\begin{array}{l}\text { Other biomass and waste } \\
\text { fuels }\end{array}$ & Electrostatic precipitator: 1 field & $90 \%$ No control & 4,515 & 4,515 & 27.17 & 10,904 \\
\hline $\begin{array}{l}\text { Power \& district heat plants - new (excl. } \\
\text { coal) }\end{array}$ & Heavy fuel oil & Good housekeeping: industrial oil boilers & $40 \%$ No control & 5,222 & 5,222 & 27.17 & 10,918 \\
\hline Industrial furnaces & Biomass fuels & High efficiency deduster & $90 \% \mathrm{ESP}_{1}$ & 1,226 & 6,042 & 26.87 & 12,708 \\
\hline Medium boilers $(<50 \mathrm{MW})$ - automatic & Fuelwood & High efficiency deduster & go \% cyclone & 8,172 & 6,106 & 26.60 & 14,397 \\
\hline $\begin{array}{l}\text { Power \& district heat plants - existing } \\
\text { (excl. coal) }\end{array}$ & Heavy fuel oil & Good housekeeping: industrial oil boilers & $50 \%$ No control & 6,191 & 6,191 & 26.59 & 14,449 \\
\hline Lime production & No fuel use & Electrostatic precipitator: 2 fields & $60 \% \mathrm{ESP}_{1}$ & 2,217 & 6,597 & 26.56 & 14,665 \\
\hline Industrial furnaces & Heavy fuel oil & Good housekeeping: industrial oil boilers & $90 \%$ No control & 6,780 & 6,780 & 26.51 & 14,992 \\
\hline Lime production & No fuel use & High efficiency deduster & $60 \% \mathrm{ESP}_{2}$ & 2,452 & 9,948 & 26.48 & 15,318 \\
\hline Industrial furnaces & $\begin{array}{l}\text { Derived coal (coke, } \\
\text { briquettes) }\end{array}$ & Electrostatic precipitator: 1 field & $90 \%$ No control & 10,091 & 10,091 & 26.45 & 15,626 \\
\hline $\begin{array}{l}\text { Power \& district heat plants - new (excl. } \\
\text { coal) }\end{array}$ & Heavy fuel oil & High efficiency deduster & $90 \%$ Good practice & 8,891 & 10,474 & 26.43 & 15,768 \\
\hline Medium boilers ( $<1 \mathrm{MW})$ - manual & Fuelwood & High efficiency deduster & $90 \%$ cyclone & 14,271 & 10,767 & 25.81 & 22,415 \\
\hline Flaring in gas \& oil industry & No fuel use & $\begin{array}{l}\text { Good practice in oil and gas industry- } \\
\text { flaring }\end{array}$ & $100 \%$ No control & 12,067 & 12,067 & 25.79 & 22,763 \\
\hline Briquettes production & No fuel use & Electrostatic precipitator: 1 field & $90 \%$ No control & 12,092 & 12,092 & 25.77 & 22,989 \\
\hline $\begin{array}{l}\text { Production of glass fiber, gypsum, PVC, } \\
\text { other }\end{array}$ & No fuel use & High efficiency deduster & $90 \% \mathrm{ESP}_{1}$ & 2,607 & 12,215 & 25.76 & 23,030 \\
\hline $\begin{array}{l}\text { Power \& district heat plants - existing } \\
\text { (excl. coal) }\end{array}$ & Heavy fuel oil & High efficiency deduster & $90 \%$ Good practice & 10,518 & 12,385 & 25.73 & 23,465 \\
\hline Medium boilers ( $<50 \mathrm{MW})$ - automatic & Fuelwood & Cyclone & $90 \%$ No control & 12,924 & 12,924 & 25.61 & 25,019 \\
\hline $\begin{array}{l}\text { Production of glass fiber, gypsum, PVC, } \\
\text { other }\end{array}$ & No fuel use & Electrostatic precipitator: 2 fields & $10 \% \mathrm{ESP}_{1}$ & 2,330 & 12,958 & 25.61 & 25,022 \\
\hline
\end{tabular}




\begin{tabular}{|c|c|c|c|c|c|c|c|}
\hline Sector & Fuel & Abatement & $\begin{array}{r}\text { Replacing (\% of activity } \\
\text { data) }\end{array}$ & $\begin{array}{r}\text { Unit cost, } \\
\text { EUR/t } \mathrm{PM}_{2.5}\end{array}$ & $\begin{array}{r}\text { Marginal cost, } \\
\text { EUR/t PM }\end{array}$ & $\begin{array}{r}\text { Remaining } \\
\text { emissions, kt }\end{array}$ & $\begin{array}{r}\text { Accumulated costs, } \\
\text { th EUR }\end{array}$ \\
\hline Single house boilers $(<50 \mathrm{~kW})$ - manual & Fuelwood & Biomass single house boiler improved & $90 \%$ No control & 13,267 & 13,267 & 25.33 & 28,646 \\
\hline Industrial furnaces & Heavy fuel oil & High efficiency deduster & go \% Good practice & 17,043 & 21,506 & 25.22 & 31,031 \\
\hline Heating stoves & Fuelwood & Improved stove-biomass & $40 \%$ No control & 21,723 & 21,723 & 22.73 & 85,188 \\
\hline Medium boilers ( $<1 \mathrm{MW})$ - manual & Fuelwood & Cyclone & $90 \%$ No control & 22,329 & 22,329 & 22.46 & 91,181 \\
\hline Single house boilers $(<50 \mathrm{~kW})$ - manual & Fuelwood & Biomass single house boiler new & $90 \%$ imroved & 16,219 & 25,075 & 22.37 & 93,465 \\
\hline Industrial furnaces & $\begin{array}{l}\text { Other biomass and waste } \\
\text { fuels }\end{array}$ & High efficiency deduster & $90 \% \mathrm{ESP}_{1}$ & 6,069 & 30,155 & 22.35 & 93,960 \\
\hline Single house boilers $(<50 \mathrm{~kW})$ - manual & Fuelwood & $\begin{array}{l}\text { Biomass single house boiler - pellets and } \\
\text { electrostatic precipitator }\end{array}$ & $90 \%$ new & 18,944 & 30,416 & 22.27 & 96,591 \\
\hline Heating stoves & Fuelwood & New stove with electrostatic precipitator & $50 \%$ new & 50,540 & 39,269 & 21.49 & 127,137 \\
\hline $\begin{array}{l}\text { Small industrial and business facilities - } \\
\text { fugitive }\end{array}$ & No fuel use & $\begin{array}{l}\text { Good practice: ind.process - stage } 2 \\
\text { (fugitive) }\end{array}$ & $50 \%$ good practice 1 & 161,567 & 47,106 & 21.39 & 132,051 \\
\hline Heating stoves & Hard coal, grade 1 & Improved stove-coal & $90 \%$ No control & 65,994 & 65,994 & 21.39 & 132,099 \\
\hline Industrial furnaces & $\begin{array}{l}\text { Derived coal (coke, } \\
\text { briquettes) }\end{array}$ & High efficiency deduster & $90 \% \mathrm{ESP}_{1}$ & 13,627 & 68,432 & 21.38 & 132,234 \\
\hline Heating stoves & $\begin{array}{l}\text { Brown coal/lignite grade } 2 \\
\text { (also peat) }\end{array}$ & Improved stove - coal & $90 \%$ No control & 74,243 & 74,243 & 20.49 & 198,519 \\
\hline Residential-commercial & Heavy fuel oil & Good housekeeping: domestic oil boilers & $90 \%$ No control & 82,503 & 82,503 & 20.49 & 198,571 \\
\hline Briquettes production & No fuel use & High efficiency deduster & $90 \% \mathrm{ESP}_{1}$ & 16,365 & 82,600 & 20.49 & 198,670 \\
\hline Fireplaces & Fuelwood & Improved fireplace & $90 \%$ No control & 86,992 & 86,992 & 20.37 & 209,106 \\
\hline Heating stoves & Fuelwood & New stove with electrostatic precipitator & $40 \%$ improved & 50,540 & 106,017 & 19.07 & 346,401 \\
\hline Fireplaces & Fuelwood & New fireplace & $90 \%$ improved & 102,418 & 128,525 & 19.00 & 355,512 \\
\hline $\begin{array}{l}\text { Small industrial and business facilities - } \\
\text { fugitive }\end{array}$ & No fuel use & $\begin{array}{l}\text { Good practice: ind.process - stage } 2 \\
\text { (fugitive) }\end{array}$ & $30 \%$ No control & 161,567 & 161,567 & 18.88 & 375,739 \\
\hline Heating stoves & Fuelwood & Pellet stove with electrostatic precipitator & $90 \%$ new with ESP & 55,829 & 199,460 & 18.56 & 438,342 \\
\hline Heating stoves & Hard coal, grade 1 & New stove - coal & $90 \%$ improved & 122,111 & 206,288 & 18.56 & 438,442 \\
\hline
\end{tabular}




\begin{tabular}{|c|c|c|c|c|c|c|c|}
\hline Sector & Fuel & Abatement & $\begin{array}{r}\text { Replacing (\% of activity } \\
\text { data) }\end{array}$ & $\begin{array}{r}\text { Unit cost, } \\
\text { EUR/t } P M_{2.5}\end{array}$ & $\begin{array}{r}\text { Marginal cost, } \\
\text { EUR/t PM }\end{array}$ & $\begin{array}{r}\text { Remaining } \\
\text { emissions, kt }\end{array}$ & $\begin{array}{r}\text { Accumulated costs } \\
\text { th EUF }\end{array}$ \\
\hline Heating stoves & $\begin{array}{l}\text { Brown coal/lignite grade } 2 \\
\text { (also peat) }\end{array}$ & New stove - coal & $90 \%$ improved & 137,375 & 232,074 & 17.97 & 576,575 \\
\hline Ploughing, tilling, harvesting & No fuel use & $\begin{array}{l}\text { Low-till farming, alternative cereal } \\
\text { harvesting }\end{array}$ & $90 \%$ No control & 334,859 & 334,859 & 17.91 & 594,652 \\
\hline Poultry & No fuel use & Feed modification (all livestock) & 50 No control & 458,546 & 458,546 & 17.88 & 611,755 \\
\hline Pigs & No fuel use & Feed modification (all livestock) & $90 \%$ No control & 580,724 & 580,724 & 17.85 & 630,104 \\
\hline Other cattle & No fuel use & Hay-silage for cattle & $90 \%$ No control & 645,585 & 645,585 & 17.83 & 640,461 \\
\hline Dairy cattle & No fuel use & Hay-silage for cattle & $90 \%$ No control & 645,585 & 645,585 & 17.82 & 645,729 \\
\hline Construction activities & No fuel use & Spraying water at construction places & $90 \%$ no control & 860,779 & 860,779 & 17.81 & 654,793 \\
\hline Residential-commercial & Diesel & Good housekeeping: domestic oil boilers & $90 \%$ No control & $1,055,593$ & $1,055,593$ & 17.81 & 654,798 \\
\hline
\end{tabular}

Table 15: $\mathrm{PM}_{2.5}$ cost curve specification (stationary sources) - Denmark

\begin{tabular}{|c|c|c|c|c|c|c|c|}
\hline Sector & Fuel & Abatement & $\begin{array}{l}\text { Replacing (\% of } \\
\text { activity data) }\end{array}$ & $\begin{array}{r}\text { Unit cost, } \\
\text { EUR/t } \text { PM }_{2.5}\end{array}$ & $\begin{array}{r}\text { Marginal cost, } \\
\text { EUR/t } \text { PM }_{2.5}\end{array}$ & $\begin{array}{r}\text { Remaining } \\
\text { emissions, kt }\end{array}$ & $\begin{array}{r}\text { Accumulated costs, } \\
\text { th EUR }\end{array}$ \\
\hline Electric arc furnace & No fuel use & High efficiency deduster & $1 \%$ no control & 80 & 80 & 11.08 & 2 \\
\hline Trash burning & No fuel use & Ban on open burning & $100 \%$ no control & 99 & 99 & 10.95 & 16 \\
\hline Agricultural waste burning & No fuel use & Ban on open burning & $100 \%$ no control & 104 & 104 & 10.76 & 35 \\
\hline Cast iron (grey iron foundries) & No fuel use & Electrostatic precipitator: 1 field & $25 \%$ cyclone & 374 & 229 & 10.68 & 52 \\
\hline Refineries & No fuel use & Electrostatic precipitator: 1 field & $1 \%$ no control & 397 & 397 & 10.68 & 54 \\
\hline Medium boilers ( $<50 M W)$ - automatic & Hard coal, grade 1 & High efficiency deduster & $60 \% \mathrm{CYC}$ & 768 & 637 & 10.64 & 78 \\
\hline Medium boilers ( $<50 M W)$ - automatic & Hard coal, grade 1 & High efficiency deduster & $40 \%$ no control & 768 & 768 & 10.61 & 105 \\
\hline Chemical industry (boilers) & Biomass fuels & Electrostatic precipitator: 1 field & $5 \%$ cyclone & 1,111 & 873 & 10.60 & 106 \\
\hline $\begin{array}{l}\text { Other industry (boilers; liquid and } \\
\text { gaseous fuels) }\end{array}$ & Biomass fuels & Electrostatic precipitator: 1 field & $5 \%$ cyclone & 1,111 & 873 & 10.58 & 124 \\
\hline
\end{tabular}




\begin{tabular}{|c|c|c|c|c|c|c|c|}
\hline Sector & Fuel & Abatement & $\begin{array}{r}\text { Replacing (\% of } \\
\text { activity data) }\end{array}$ & $\begin{array}{r}\text { Unit cost, } \\
\text { EUR/t } \mathrm{PM}_{2.5}\end{array}$ & $\begin{array}{l}\text { Marginal cost, } \\
\text { EUR/t PM }\end{array}$ & $\begin{array}{r}\text { Remaining } \\
\text { emissions, kt }\end{array}$ & $\begin{array}{r}\text { Accumulated costs, } \\
\text { th EUR }\end{array}$ \\
\hline Paper \& pulp (boilers) & Biomass fuels & Electrostatic precipitator: 1 field & $5 \%$ cyclone & 1,111 & 873 & 10.58 & 129 \\
\hline Meat frying, food preparation, BBO & No fuel use & Filters in households (kitchen) & $100 \%$ no control & 1,207 & 1,207 & 10.53 & 182 \\
\hline $\begin{array}{l}\text { Power \& district heat plants - new coal } \\
\text { (>50 MWth) }\end{array}$ & Hard coal, grade 1 & High efficiency deduster & $5 \% \mathrm{ESP}_{2}$ & 808 & 1,720 & 10.53 & 182 \\
\hline $\begin{array}{l}\text { Power \& district heat plants - existing } \\
\text { coal (>50 MWth) }\end{array}$ & Hard coal, grade 1 & High efficiency deduster & $5 \% \mathrm{ESP}_{2}$ & 901 & 2,143 & 10.53 & 186 \\
\hline Industry: Other combustion, pulverized & Hard coal, grade 1 & High efficiency deduster & $100 \% \mathrm{ESP} 2$ & 845 & 2,155 & 10.53 & 187 \\
\hline Refineries & No fuel use & Electrostatic precipitator: 2 fields & $10 \% \mathrm{ESP}_{1}$ & 452 & 2,166 & 10.53 & 191 \\
\hline Cast iron (grey iron foundries) & No fuel use & High efficiency deduster & $25 \% \mathrm{ESP}_{1}$ & 500 & 2,462 & 10.52 & 208 \\
\hline Refineries & No fuel use & High efficiency deduster & $99 \% \mathrm{ESP} 2$ & 517 & 2,591 & 10.51 & 248 \\
\hline Medium boilers $(<1 \mathrm{MW})$ - manual & Fuelwood & Pellet boiler & $100 \%$ no control & 2,827 & 2,827 & 10.48 & 316 \\
\hline $\begin{array}{l}\text { Other industry (large coal boilers; > } 50 \\
\text { MWth) }\end{array}$ & Hard coal, grade 1 & High efficiency deduster & $100 \% \mathrm{ESP} 2$ & 1,034 & 3,120 & 10.48 & 328 \\
\hline Medium boilers ( $<50 \mathrm{MW})$ - automatic & Fuelwood & Pellet boiler & $100 \%$ no control & 3,177 & 3,177 & 10.34 & 759 \\
\hline $\begin{array}{l}\text { Power \& district heat plants - existing } \\
\text { coal (<50 MWth) }\end{array}$ & Hard coal, grade 1 & High efficiency deduster & $40 \% \mathrm{ESP}_{2}$ & 1,047 & 3,911 & 10.34 & 761 \\
\hline Industrial furnaces & Biomass fuels & High efficiency deduster & $100 \% \mathrm{ESP}_{2}$ & 956 & 4,045 & 10.32 & 840 \\
\hline Heating stoves & Fuelwood & Improved stove - biomass & $35 \%$ no control & 5,058 & 5,058 & 8.13 & 11,959 \\
\hline Cast iron (grey iron foundries) (fugitive) & No fuel use & $\begin{array}{l}\text { Good practice: ind.process - stage } 2 \\
\text { (fugitive) }\end{array}$ & $1 \%$ no control & 5,274 & 5,274 & 8.12 & 11,962 \\
\hline Heating stoves & Hard coal, grade 1 & Briquette stove & $40 \%$ no control & 6,496 & 6,496 & 8.12 & 11,986 \\
\hline Chemical industry (boilers) & Biomass fuels & High efficiency deduster & $5 \% \mathrm{ESP}_{1}$ & 1,464 & 6,939 & 8.12 & 11,986 \\
\hline $\begin{array}{l}\text { Other industry (boilers; liquid and } \\
\text { gaseous fuels) }\end{array}$ & Biomass fuels & High efficiency deduster & $5 \% \mathrm{ESP}_{1}$ & 1,464 & 6,939 & 8.12 & 12,000 \\
\hline Paper \& pulp (boilers) & Biomass fuels & High efficiency deduster & $5 \% \mathrm{ESP}_{1}$ & 1,464 & 6,939 & 8.12 & 12,004 \\
\hline Fireplaces & Fuelwood & Improved fireplace & $100 \%$ no control & 8,707 & 8,707 & 8.02 & 12,906 \\
\hline
\end{tabular}




\begin{tabular}{|c|c|c|c|c|c|c|c|}
\hline Sector & Fuel & Abatement & $\begin{array}{r}\text { Replacing (\% of } \\
\text { activity data) }\end{array}$ & $\begin{array}{r}\text { Unit cost, } \\
\text { EUR/t } \mathrm{PM}_{2.5}\end{array}$ & $\begin{array}{r}\text { Marginal cost, } \\
\text { EUR/t PM }\end{array}$ & $\begin{array}{r}\text { Remaining } \\
\text { emissions, kt }\end{array}$ & $\begin{array}{r}\text { Accumulated costs, } \\
\text { th EUR }\end{array}$ \\
\hline $\begin{array}{l}\text { Power \& district heat plants - new (excl. } \\
\text { coal) }\end{array}$ & $\begin{array}{l}\text { Other biomass and waste } \\
\text { fuels }\end{array}$ & High efficiency deduster & $40 \% \mathrm{ESP}_{2}$ & 2,465 & 8,990 & 8.01 & 12,951 \\
\hline Heating stoves & Fuelwood & Pellet stove & $30 \%$ new & 27,989 & 13,636 & 7.56 & 19,069 \\
\hline Fuel conversion - combustion & Heavy fuel oil & High efficiency deduster & $100 \%$ good practice & 11,908 & 15,199 & 7.56 & 19,069 \\
\hline Industrial furnaces & Heavy fuel oil & High efficiency deduster & $100 \%$ good practice & 13,417 & 17,125 & 7.56 & 19,080 \\
\hline Transformation sector (boilers) & Heavy fuel oil & High efficiency deduster & $100 \%$ good practice & 23,239 & 29,925 & 7.56 & 19,081 \\
\hline $\begin{array}{l}\text { Other industry (boilers; liquid and } \\
\text { gaseous fuels) }\end{array}$ & Heavy fuel oil & High efficiency deduster & $100 \%$ good practice & 23,239 & 29,925 & 7.56 & 19,086 \\
\hline Paper \& pulp (boilers) & Heavy fuel oil & High efficiency deduster & $100 \%$ good practice & 23,239 & 29,925 & 7.56 & 19,087 \\
\hline Medium boilers ( $<50 \mathrm{MW})$ - automatic & Fuelwood & High efficiency deduster & $100 \%$ pellet boiler & 6,057 & 31,696 & 7.55 & 19,570 \\
\hline $\begin{array}{l}\text { Power \& district heat plants - new (excl. } \\
\text { coal) }\end{array}$ & Heavy fuel oil & High efficiency deduster & $28 \%$ good practice & 29,024 & 33,646 & 7.54 & 19,797 \\
\hline $\begin{array}{l}\text { Power \& district heat plants - existing } \\
\text { (excl. coal) }\end{array}$ & Heavy fuel oil & High efficiency deduster & $58 \%$ good practice & 50,617 & 58,405 & 7.53 & 20,131 \\
\hline Heating stoves & Fuelwood & Pellet stove & $70 \%$ improved & 27,989 & 73,134 & 5.30 & 183,465 \\
\hline Medium boilers (<1MW) - manual & Fuelwood & High efficiency deduster & $100 \%$ pellet boiler & 10,500 & 78,786 & 5.30 & 183,675 \\
\hline Fireplaces & Fuelwood & New fireplace & $40 \%$ improved & 41,493 & 96,978 & 5.27 & 186,050 \\
\hline $\begin{array}{l}\text { Small industrial and business facilities - } \\
\text { fugitive }\end{array}$ & No fuel use & $\begin{array}{l}\text { Good practice: ind.process - stage } 2 \\
\text { (fugitive) }\end{array}$ & $10 \%$ no control & 121,304 & 121,304 & 5.24 & 189,481 \\
\hline Heating stoves & Hard coal, grade 1 & New stove - coal & $40 \%$ Improved & 88,362 & 192,226 & 5.24 & 189,640 \\
\hline Ploughing, tilling, harvesting & No fuel use & $\begin{array}{l}\text { Low-till farming, alternative cereal } \\
\text { harvesting }\end{array}$ & $100 \%$ no control & 334,859 & 334,859 & 5.22 & 196,880 \\
\hline Poultry & No fuel use & Feed modification (all livestock) & $100 \%$ no control & 458,546 & 458,546 & 5.20 & 207,359 \\
\hline Other cattle & No fuel use & Feed modification (all livestock) & $100 \%$ no control & 458,546 & 458,546 & 5.19 & 209,169 \\
\hline
\end{tabular}




\begin{tabular}{|c|c|c|c|c|c|c|c|}
\hline Sector & Fuel & Abatement & $\begin{array}{l}\text { Replacing (\% of } \\
\text { activity data) }\end{array}$ & $\begin{array}{r}\text { Unit cost, } \\
\text { EUR/t PM } 2.5\end{array}$ & $\begin{array}{r}\text { Marginal cost, } \\
\text { EUR/t PM }_{2.5}\end{array}$ & $\begin{array}{r}\text { Remaining } \\
\text { emissions, kt }\end{array}$ & $\begin{array}{r}\text { Accumulated costs, } \\
\text { th EUR }\end{array}$ \\
\hline Dairy cattle & No fuel use & Feed modification (all livestock) & $100 \%$ no control & 458,546 & 458,546 & 5.19 & 211,060 \\
\hline Pigs & No fuel use & Feed modification (all livestock) & $100 \%$ no control & 580,724 & 580,724 & 5.10 & 263,533 \\
\hline Construction activities & No fuel use & Spraying water at construction places & $100 \%$ no control & 853,309 & 853,309 & 5.10 & 267,356 \\
\hline
\end{tabular}

Table 16: $\mathrm{PM}_{2.5}$ cost curve specification (stationary sources) - Finland

\begin{tabular}{|c|c|c|c|c|c|c|c|}
\hline Sector & Fuel & Abatement & $\begin{array}{r}\text { Replacing (\% of activity } \\
\text { data) }\end{array}$ & $\begin{array}{l}\text { Unit cost, } \\
\text { EUR/t PM } 2.5\end{array}$ & $\begin{array}{r}\text { Marginal cost, } \\
\text { EUR/t PM }\end{array}$ & $\begin{array}{r}\begin{array}{r}\text { Remaining } \\
\text { emissions, kt }\end{array}\end{array}$ & $\begin{array}{r}\text { Accumulated costs, } \\
\text { th EUR }\end{array}$ \\
\hline Agricultural waste burning & No fuel use & Ban on open burning & $100 \%$ no control & 90 & 90 & 17.89 & 1 \\
\hline Trash burning & No fuel use & Ban on open burning & $100 \%$ no control & 92 & 92 & 17.48 & 39 \\
\hline Fuel conversion - combustion & $\begin{array}{l}\text { Other biomass and waste } \\
\text { fuels }\end{array}$ & Electrostatic precipitator: 1 field & $100 \%$ cyclone & 211 & 108 & 17.24 & 65 \\
\hline Electric arc furnace & No fuel use & Cyclone & $1 \%$ no control & 127 & 127 & 17.19 & 71 \\
\hline Fuel conversion - combustion & $\begin{array}{l}\text { Other biomass and waste } \\
\text { fuels }\end{array}$ & High efficiency deduster & $100 \% \mathrm{ESP}_{1}$ & 246 & 794 & 17.17 & 90 \\
\hline Medium boilers ( $<50 \mathrm{MW})$ - automatic & Hard coal, grade 1 & High efficiency deduster & $60 \%$ cyclone & 1,041 & 889 & 17.10 & 145 \\
\hline Medium boilers ( $<50 \mathrm{MW})$ - automatic & Hard coal, grade 1 & High efficiency deduster & $40 \%$ no control & 1,041 & 1,041 & 17.04 & 207 \\
\hline $\begin{array}{l}\text { Glass production (flat, blown, container } \\
\text { glass) }\end{array}$ & No fuel use & High efficiency deduster & $49 \% \mathrm{ESP}_{2}$ & 241 & 1,055 & 17.04 & 216 \\
\hline Meat frying, food preparation, BBO & No fuel use & Filters in households (kitchen) & $100 \%$ no control & 1,207 & 1,207 & 16.99 & 268 \\
\hline Agglomeration plant-sinter & No fuel use & Cyclone & $1 \%$ no control & 1,456 & 1,456 & 16.99 & 276 \\
\hline Single house boilers $(<50 \mathrm{~kW})$ - manual & Fuelwood & Biomass single house boiler improved & $19 \%$ no control & 1,971 & 1,971 & 15.68 & 2,851 \\
\hline Refineries & No fuel use & Electrostatic precipitator: 2 fields & $100 \% \mathrm{ESP}_{1}$ & 452 & 2,166 & 15.64 & 2,930 \\
\hline Industry: Other combustion, pulverized & Brown coal/lignite grade 1 & High efficiency deduster & $100 \% \mathrm{ESP}_{1}$ & 721 & 2,435 & 15.64 & 2,943 \\
\hline $\begin{array}{l}\text { Power \& district heat plants - existing } \\
\text { coal (>50 MWth) }\end{array}$ & Hard coal, grade 1 & High efficiency deduster & $22 \% \mathrm{ESP} 2$ & 918 & 2,582 & 15.53 & 3,226 \\
\hline
\end{tabular}




\begin{tabular}{|c|c|c|c|c|c|c|c|}
\hline Sector & Fuel & Abatement & $\begin{array}{r}\text { Replacing (\% of activity } \\
\text { data) }\end{array}$ & $\begin{array}{r}\text { Unit cost, } \\
\text { EUR/t } \text { PM }_{2.5}\end{array}$ & $\begin{array}{l}\text { Marginal cost, } \\
\text { EUR/t } \mathrm{PM}_{2.5}\end{array}$ & $\begin{array}{r}\text { Remaining } \\
\text { emissions, kt }\end{array}$ & $\begin{array}{r}\text { Accumulated costs, } \\
\text { th EUR }\end{array}$ \\
\hline Refineries & No fuel use & High efficiency deduster & $100 \% \mathrm{ESP} 2$ & 517 & 2,591 & 15.49 & 3,320 \\
\hline $\begin{array}{l}\text { Power \& district heat plants - new coal } \\
\text { (>50 MWth) }\end{array}$ & Brown coal/lignite grade 1 & High efficiency deduster & $59 \% \mathrm{ESP}_{2}$ & 888 & 2,800 & 15.46 & 3,408 \\
\hline Medium boilers ( $<1 \mathrm{MW})$ - manual & Fuelwood & Pellet boiler & $100 \%$ no control & 2,827 & 2,827 & 15.42 & 3,529 \\
\hline $\begin{array}{l}\text { Production of glass fiber, gypsum, PVC, } \\
\text { other }\end{array}$ & No fuel use & Cyclone & $1 \%$ no control & 3,044 & 3,044 & 15.42 & 3,529 \\
\hline $\begin{array}{l}\text { Power \& district heat plants - new (excl. } \\
\text { coal) }\end{array}$ & Biomass fuels & High efficiency deduster & $100 \% \mathrm{ESP}_{2}$ & 662 & 3,085 & 15.03 & 4,726 \\
\hline $\begin{array}{l}\text { Power \& district heat plants - existing } \\
\text { coal (>50 MWth) }\end{array}$ & Brown coal/lignite grade 1 & High efficiency deduster & $45 \% \mathrm{ESP}_{2}$ & 977 & 3,198 & 14.89 & 5,190 \\
\hline Industrial furnaces & Biomass fuels & High efficiency deduster & $84 \% \mathrm{ESP}_{2}$ & 765 & 3,467 & 14.85 & 5,308 \\
\hline Agglomeration plant - sinter & No fuel use & High efficiency deduster & $99 \% \mathrm{ESP}_{2}$ & 834 & 3,648 & 14.80 & 5,503 \\
\hline Industrial furnaces & Biomass fuels & High efficiency deduster & $16 \% \mathrm{ESP}_{1}$ & 765 & 3,659 & 14.79 & 5,551 \\
\hline Cast iron (grey iron foundries) (fugitive) & No fuel use & $\begin{array}{l}\text { Good practice: ind.process - stage } 2 \\
\text { (fugitive) }\end{array}$ & $1 \%$ no control & 5,274 & 5,274 & 14.78 & 5,558 \\
\hline Medium boilers ( $<50 \mathrm{MW}$ ) - automatic & Fuelwood & Pellet boiler & $100 \%$ no control & 5,952 & 5,952 & 14.53 & 7,069 \\
\hline Chemical industry (boilers) & Heavy fuel oil & High efficiency deduster & $28 \%$ good practice & 4,613 & 6,028 & 14.53 & 7,070 \\
\hline Transformation sector (boilers) & Heavy fuel oil & High efficiency deduster & $28 \%$ good practice & 4,613 & 6,028 & 14.53 & 7,092 \\
\hline $\begin{array}{l}\text { Other industry (boilers; liquid and } \\
\text { gaseous fuels) }\end{array}$ & Heavy fuel oil & High efficiency deduster & $28 \%$ good practice & 4,613 & 6,028 & 14.53 & 7,093 \\
\hline Paper \& pulp (boilers) & Heavy fuel oil & High efficiency deduster & $28 \%$ good practice & 4,613 & 6,028 & 14.53 & 7,094 \\
\hline $\begin{array}{l}\text { Power \& district heat plants - existing } \\
\text { (excl. coal) }\end{array}$ & Biomass fuels & High efficiency deduster & $100 \% \mathrm{ESP}_{2}$ & 1,531 & 6,156 & 13.80 & 11,562 \\
\hline Lime production & No fuel use & High efficiency deduster & $50 \% \mathrm{ESP}_{2}$ & 1,913 & 7,427 & 13.79 & 11,636 \\
\hline Fuel conversion - combustion & Heavy fuel oil & High efficiency deduster & $100 \%$ good practice & 6,076 & 7,505 & 13.74 & 12,023 \\
\hline $\begin{array}{l}\text { Power \& district heat plants - existing } \\
\text { coal (<50 MWth) }\end{array}$ & Brown coal/lignite grade 1 & High efficiency deduster & $98 \% \mathrm{ESP}_{2}$ & 3,140 & 8,103 & 13.72 & 12,205 \\
\hline
\end{tabular}




\begin{tabular}{|c|c|c|c|c|c|c|c|}
\hline Sector & Fuel & Abatement & $\begin{array}{r}\text { Replacing (\% of activity } \\
\text { data) }\end{array}$ & $\begin{array}{r}\text { Unit cost, } \\
\text { EUR/t } \mathrm{PM}_{2.5}\end{array}$ & $\begin{array}{r}\text { Marginal cost, } \\
\text { EUR/t PM } \text { PM.5 }_{2}\end{array}$ & $\begin{array}{r}\text { Remaining } \\
\text { emissions, kt }\end{array}$ & $\begin{array}{r}\text { Accumulated costs, } \\
\text { th EUR }\end{array}$ \\
\hline $\begin{array}{l}\text { Production of glass fiber, gypsum, PVC, } \\
\text { other }\end{array}$ & No fuel use & High efficiency deduster & $18 \%$ cyclone & 2,040 & 9,246 & 13.71 & 12,247 \\
\hline Fireplaces & Fuelwood & Improved fireplace & $100 \%$ no control & 9,254 & 9,254 & 12.93 & 19,491 \\
\hline $\begin{array}{l}\text { Other industry (small coal boilers } ;<50 \\
\text { MWth) }\end{array}$ & Brown coal/lignite grade 1 & High efficiency deduster & $86 \% \mathrm{ESP}_{2}$ & 3,980 & 10,014 & 12.93 & 19,492 \\
\hline $\begin{array}{l}\text { Power \& district heat plants - existing } \\
\text { coal (<50 MWth) }\end{array}$ & Brown coal/lignite grade 1 & High efficiency deduster & $2 \% \mathrm{ESP}_{1}$ & 3,140 & 12,955 & 12.93 & 19,504 \\
\hline $\begin{array}{l}\text { Other industry (boilers; liquid and } \\
\text { gaseous fuels) }\end{array}$ & $\begin{array}{l}\text { Derived coal (coke, } \\
\text { briquettes) }\end{array}$ & High efficiency deduster & $100 \% \mathrm{ESP}_{1}$ & 2,985 & 13,601 & 12.93 & 19,505 \\
\hline $\begin{array}{l}\text { Other industry (small coal boilers } ;<50 \\
\text { MWth) }\end{array}$ & Brown coal/lignite grade 1 & High efficiency deduster & $14 \% \mathrm{ESP}_{1}$ & 3,980 & 15,906 & 12.93 & 19,506 \\
\hline Heating stoves & Fuelwood & Pellet stove & $21 \%$ new & 113,388 & 23,688 & 12.53 & 28,947 \\
\hline Pig iron, blast furnace & No fuel use & High efficiency deduster & $100 \% \mathrm{ESP}_{2}$ & 5,315 & 24,929 & 12.52 & 29,251 \\
\hline Single house boilers $(<50 \mathrm{~kW})$ - manual & Fuelwood & Biomass single house boiler - pellets & $78 \%$ improved & 3,740 & 25,716 & 12.09 & 40,351 \\
\hline Industrial furnaces & Heavy fuel oil & High efficiency deduster & $100 \%$ good practice & 21,179 & 27,653 & 12.03 & 41,900 \\
\hline Industrial furnaces & $\begin{array}{l}\text { Derived coal (coke, } \\
\text { briquettes) }\end{array}$ & High efficiency deduster & $100 \% \mathrm{ESP}_{1}$ & 8,144 & 39,585 & 12.01 & 42,844 \\
\hline Medium boilers ( $<50 \mathrm{MW})$ - automatic & Fuelwood & High efficiency deduster & $60 \%$ pellet boilers & 11,321 & 59,104 & 11.99 & 43,855 \\
\hline $\begin{array}{l}\text { Power \& district heat plants - new (excl. } \\
\text { coal) }\end{array}$ & Heavy fuel oil & High efficiency deduster & $28 \%$ good practice & 45,912 & 59,741 & 11.98 & 44,550 \\
\hline Medium boilers ( $<1 \mathrm{MW})$ - manual & Fuelwood & High efficiency deduster & $100 \%$ pellet boilers & 10,500 & 78,786 & 11.97 & 44,927 \\
\hline Fireplaces & Fuelwood & New fireplace & $40 \%$ improved & 44,099 & 103,067 & 11.79 & 63,998 \\
\hline Heating stoves & Fuelwood & Pellet stove & $26 \%$ no control & 113,388 & 113,388 & 10.45 & 215,969 \\
\hline $\begin{array}{l}\text { Small industrial and business facilities - } \\
\text { fugitive }\end{array}$ & No fuel use & $\begin{array}{l}\text { Good practice: ind.process - stage } 2 \\
\text { (fugitive) }\end{array}$ & $20 \%$ no control & 121,304 & 121,304 & 10.39 & 222,611 \\
\hline $\begin{array}{l}\text { Power \& district heat plants - existing } \\
\text { (excl. coal) }\end{array}$ & Heavy fuel oil & High efficiency deduster & $28 \%$ good practice & 97,479 & 126,512 & 10.39 & 222,757 \\
\hline Heating stoves & Fuelwood & Pellet stove & $53 \%$ improved & 113,388 & 172,475 & 8.81 & 495,418 \\
\hline
\end{tabular}




\begin{tabular}{|c|c|c|c|c|c|c|c|}
\hline Sector & Fuel & Abatement & $\begin{array}{r}\text { Replacing (\% of activity } \\
\text { data) }\end{array}$ & $\begin{array}{r}\text { Unit cost, } \\
\text { EUR/t } \mathrm{PM}_{2.5}\end{array}$ & $\begin{array}{r}\text { Marginal cost, } \\
\text { EUR/t } \mathrm{PM}_{2.5}\end{array}$ & $\begin{array}{r}\text { Remaining } \\
\text { emissions, kt }\end{array}$ & $\begin{array}{r}\text { Accumulated costs, } \\
\text { th EUR }\end{array}$ \\
\hline Ploughing, tilling, harvesting & No fuel use & $\begin{array}{l}\text { Low-till farming, alternative cereal } \\
\text { harvesting }\end{array}$ & $100 \%$ no control & 334,859 & 334,859 & 8.79 & 502,343 \\
\hline Poultry & No fuel use & Feed modification (all livestock) & $100 \%$ no control & 458,546 & 458,546 & 8.78 & 507,305 \\
\hline Other cattle & No fuel use & Feed modification (all livestock) & $100 \%$ no control & 458,546 & 458,546 & 8.77 & 508,946 \\
\hline Dairy cattle & No fuel use & Feed modification (all livestock) & $100 \%$ no control & 458,546 & 458,546 & 8.77 & 509,745 \\
\hline Pigs & No fuel use & Feed modification (all livestock) & $100 \%$ no control & 580,724 & 580,724 & 8.76 & 515,543 \\
\hline Construction activities & No fuel use & Spraying water at construction places & $100 \%$ no control & 861,282 & 861,282 & 8.75 & 522,504 \\
\hline
\end{tabular}

Table 17: $\mathrm{PM}_{2.5}$ cost curve specification (stationary sources) - Sweden

\begin{tabular}{|c|c|c|c|c|c|c|c|}
\hline Sector & Fuel & Abatement & $\begin{array}{r}\text { Replacing (\% of activity } \\
\text { data) }\end{array}$ & $\begin{array}{r}\text { Unit cost, } \\
\text { EUR/t }^{P_{2.5}}\end{array}$ & $\begin{array}{r}\text { Marginal cost, } \\
\text { EUR/t } \text { PM }_{2.5}\end{array}$ & $\begin{array}{r}\text { Remaining } \\
\text { emissions, kt }\end{array}$ & $\begin{array}{r}\text { Accumulated costs, } \\
\text { th EUR }\end{array}$ \\
\hline Primary aluminium & No fuel use & Electrostatic precipitator: 1 field & $3 \%$ no control & 64 & 64 & 19.98 & 4 \\
\hline Coke oven & No fuel use & Electrostatic precipitator: 1 field & $1 \%$ no control & 85 & 85 & 19.96 & 6 \\
\hline Agricultural waste burning & No fuel use & Ban on open burning & $100 \%$ no control & 104 & 104 & 19.91 & 12 \\
\hline Electric arc furnace & No fuel use & Cyclone & $1.5 \%$ no control & 127 & 127 & 19.84 & 21 \\
\hline $\begin{array}{l}\text { Production of glass fiber, gypsum, PVC, } \\
\text { other }\end{array}$ & No fuel use & Electrostatic precipitator: 1 field & $18 \%$ cyclone & 224 & 143 & 19.81 & 24 \\
\hline Primary aluminum & No fuel use & High efficiency deduster & $42 \% \mathrm{ESP}_{1}$ & 75 & 241 & 19.75 & 38 \\
\hline Coke oven & No fuel use & High efficiency deduster & $50 \% \mathrm{ESP}_{2}$ & 103 & 356 & 19.71 & 53 \\
\hline Coke oven & No fuel use & High efficiency deduster & $50 \% \mathrm{ESP}_{1}$ & 103 & 376 & 19.62 & 86 \\
\hline $\begin{array}{l}\text { Production of glass fiber, gypsum, PVC, } \\
\text { other }\end{array}$ & No fuel use & Cyclone & $1 \%$ no control & 394 & 394 & 19.62 & 86 \\
\hline Refineries & No fuel use & Electrostatic precipitator: 1 field & $1 \%$ no control & 397 & 397 & 19.61 & 92 \\
\hline Basic oxygen furnace & No fuel use & Cyclone & $1 \%$ no control & 469 & 469 & 19.49 & 146 \\
\hline
\end{tabular}




\begin{tabular}{|c|c|c|c|c|c|c|c|}
\hline Sector & Fuel & Abatement & $\begin{array}{r}\text { Replacing (\% of activity } \\
\text { data) }\end{array}$ & $\begin{array}{r}\text { Unit cost, } \\
\text { EUR/t } \text { PM }_{2.5}\end{array}$ & $\begin{array}{r}\text { Marginal cost, } \\
\mathrm{EUR} / \mathrm{t} \mathrm{PM}_{2.5}\end{array}$ & $\begin{array}{r}\text { Remaining } \\
\text { emissions, kt }\end{array}$ & $\begin{array}{r}\text { Accumulated costs, } \\
\text { th EUR }\end{array}$ \\
\hline Industry: Other combustion, pulverized & Brown coal/lignite grade 1 & High efficiency deduster & $50 \% \mathrm{ESP}_{2}$ & 397 & 801 & 19.48 & 154 \\
\hline $\begin{array}{l}\text { Glass production (flat, blown, container } \\
\text { glass) }\end{array}$ & No fuel use & High efficiency deduster & $49 \% \mathrm{ESP} 2$ & 241 & 1,055 & 19.47 & 166 \\
\hline $\begin{array}{l}\text { Other industry (large coal boilers; > } 50 \\
\text { MWth) }\end{array}$ & Brown coal/lignite grade 1 & High efficiency deduster & $50 \% \mathrm{ESP} 2$ & 467 & 1,181 & 19.44 & 199 \\
\hline Chemical industry (boilers) & Brown coal/lignite grade 1 & High efficiency deduster & $50 \% \mathrm{ESP}_{2}$ & 472 & 1,206 & 19.44 & 199 \\
\hline Paper \& pulp (boilers) & Brown coal/lignite grade 1 & High efficiency deduster & $50 \% \mathrm{ESP}_{2}$ & 472 & 1,206 & 19.44 & 202 \\
\hline Meat frying, food preparation, BBO & No fuel use & Filters in households (kitchen) & $100 \%$ No control & 1,207 & 1,207 & 19.36 & 297 \\
\hline $\begin{array}{l}\text { Production of glass fiber, gypsum, PVC, } \\
\text { other }\end{array}$ & No fuel use & High efficiency deduster & $18 \% \mathrm{ESP}_{1}$ & 291 & 1,331 & 19.36 & 300 \\
\hline Pig iron, blast furnace & No fuel use & Electrostatic precipitator: 1 field & $10 \%$ cyclone & 3,978 & 2,076 & 19.32 & 381 \\
\hline Basic oxygen furnace & No fuel use & High efficiency deduster & $45 \% \mathrm{ESP}_{2}$ & 460 & 2,134 & 18.81 & 1,480 \\
\hline Refineries & No fuel use & Electrostatic precipitator: 2 fields & $41 \% \mathrm{ESP}_{1}$ & 452 & 2,166 & 18.79 & 1,525 \\
\hline Refineries & No fuel use & High efficiency deduster & $99 \% \mathrm{ESP} 2$ & 517 & 2,591 & 18.74 & 1,654 \\
\hline $\begin{array}{l}\text { Power \& district heat plants - new (excl. } \\
\text { coal) }\end{array}$ & Biomass fuels & High efficiency deduster & $100 \% \mathrm{ESP}_{1}$ & 605 & 2,699 & 16.56 & 7,538 \\
\hline Medium boilers $(<50 M W)$ - automatic & Fuelwood & Pellet boiler & $100 \%$ no control & 3,177 & 3,177 & 15.76 & 10,074 \\
\hline $\begin{array}{l}\text { Power \& district heat plants - existing } \\
\text { (excl. coal) }\end{array}$ & Biomass fuels & High efficiency deduster & $100 \% \mathrm{ESP}_{1}$ & 733 & 3,322 & 14.16 & 15,369 \\
\hline Industry: Other combustion, pulverized & Hard coal, grade 1 & High efficiency deduster & $50 \% \mathrm{ESP}_{2}$ & 1,108 & 3,629 & 14.14 & 15,470 \\
\hline Pig iron, blast furnace & No fuel use & Electrostatic precipitator: 1 field & $1 \%$ no control & 3,978 & 3,978 & 14.13 & 15,492 \\
\hline Industrial furnaces & Biomass fuels & High efficiency deduster & $100 \% \mathrm{ESP}_{1}$ & 930 & 4,472 & 13.78 & 17,068 \\
\hline $\begin{array}{l}\text { Other industry (large coal boilers; > } 50 \\
\text { MWth) }\end{array}$ & Hard coal, grade 1 & High efficiency deduster & $50 \% \mathrm{ESP}_{2}$ & 1,413 & 5,272 & 13.78 & 17,083 \\
\hline Paper \& pulp (boilers) & Hard coal, grade 1 & High efficiency deduster & $50 \% \mathrm{ESP} 2$ & 1,458 & 5,513 & 13.78 & 17,084 \\
\hline Chemical industry (boilers) & Biomass fuels & High efficiency deduster & $100 \% \mathrm{ESP}_{1}$ & 1,422 & 6,939 & 13.75 & 17,264 \\
\hline
\end{tabular}




\begin{tabular}{|c|c|c|c|c|c|c|c|}
\hline Sector & Fuel & Abatement & $\begin{array}{r}\text { Replacing (\% of activity } \\
\text { data) }\end{array}$ & $\begin{array}{r}\text { Unit cost, } \\
\text { EUR/t } \text { PM }_{2.5}\end{array}$ & $\begin{array}{r}\text { Marginal cost, } \\
\mathrm{EUR} / \mathrm{t} \mathrm{PM}_{2.5}\end{array}$ & $\begin{array}{r}\text { Remaining } \\
\text { emissions, kt }\end{array}$ & $\begin{array}{r}\text { Accumulated costs, } \\
\text { th EUR }\end{array}$ \\
\hline $\begin{array}{l}\text { Other industry (boilers; liquid and } \\
\text { gaseous fuels) }\end{array}$ & Biomass fuels & High efficiency deduster & $100 \% \mathrm{ESP}_{1}$ & 1,422 & 6,939 & 13.31 & 20,328 \\
\hline Paper \& pulp (boilers) & Biomass fuels & High efficiency deduster & $100 \% \mathrm{ESP}_{1}$ & 1,422 & 6,939 & 11.73 & 31,275 \\
\hline Single house boilers $(<50 \mathrm{~kW})$ - manual & Fuelwood & Biomass single house boiler new & $60 \%$ Improved & 6,671 & 10,314 & 10.95 & 39,316 \\
\hline Single house boilers $(<50 \mathrm{~kW})$ - manual & Fuelwood & Biomass single house boiler - pellets & $100 \%$ NEW & 7,458 & 13,752 & 10.30 & 48,249 \\
\hline Fuel conversion - combustion & Heavy fuel oil & High efficiency deduster & $100 \%$ good practice & 11,493 & 14,604 & 10.29 & 48,389 \\
\hline Industrial furnaces & Heavy fuel oil & High efficiency deduster & $100 \%$ good practice & 12,949 & 16,453 & 10.27 & 48,751 \\
\hline Cement production & No fuel use & High efficiency deduster & $35 \% \mathrm{ESP} 2$ & 835 & 17,130 & 10.15 & 50,854 \\
\hline Pig iron, blast furnace (fugitive) & No fuel use & $\begin{array}{l}\text { Good practice: ind.process - stage } 2 \\
\text { (fugitive) }\end{array}$ & $1 \%$ of no control & 19,412 & 19,412 & 10.14 & 50,952 \\
\hline $\begin{array}{l}\text { Power \& district heat plants - new (excl. } \\
\text { coal) }\end{array}$ & Heavy fuel oil & High efficiency deduster & $57.7 \%$ good practice & 22,583 & 26,011 & 10.14 & 51,069 \\
\hline Pig iron, blast furnace & No fuel use & High efficiency deduster & $10 \% \mathrm{ESP}_{1}$ & 5,315 & 26,040 & 10.13 & 51,165 \\
\hline Pig iron, blast furnace & No fuel use & Electrostatic precipitator: 2 fields & $1 \% \mathrm{ESP}_{1}$ & 4,702 & 27,150 & 10.13 & 51,170 \\
\hline Transformation sector (boilers) & Heavy fuel oil & High efficiency deduster & $78 \%$ good practice & 22,486 & 28,846 & 10.13 & 51,231 \\
\hline $\begin{array}{l}\text { Other industry (boilers; liquid and } \\
\text { gaseous fuels) }\end{array}$ & Heavy fuel oil & High efficiency deduster & $78 \%$ good practice & 22,486 & 28,846 & 10.13 & 51,236 \\
\hline Paper \& pulp (boilers) & Heavy fuel oil & High efficiency deduster & $78 \%$ good practice & 22,486 & 28,846 & 10.13 & 51,259 \\
\hline Medium boilers ( $<50 \mathrm{MW})$ - automatic & Fuelwood & High efficiency deduster & $100 \%$ pellet boiler & 6,057 & 31,696 & 10.04 & 54,102 \\
\hline $\begin{array}{l}\text { Power \& district heat plants - existing } \\
\text { (excl. coal) }\end{array}$ & Heavy fuel oil & High efficiency deduster & $62 \%$ good practice & 29,148 & 33,661 & 10.03 & 54,306 \\
\hline Heating stoves & Fuelwood & Pellet stove & $50 \%$ new & 71,701 & 34,931 & 9.95 & 57,356 \\
\hline Industrial furnaces & $\begin{array}{l}\text { Derived coal (coke, } \\
\text { briquettes) }\end{array}$ & High efficiency deduster & $50 \% \mathrm{ESP}_{2}$ & 10,846 & 48,385 & 9.94 & 57,686 \\
\hline $\begin{array}{l}\text { Small industrial and business facilities - } \\
\text { fugitive }\end{array}$ & No fuel use & $\begin{array}{l}\text { Good practice: ind.process - stage } 2 \\
\text { (fugitive) }\end{array}$ & $20 \%$ No control & 121,304 & 121,304 & 9.84 & 70,004 \\
\hline Heating stoves & Fuelwood & Pellet stove & $50 \%$ improved & 71,701 & 187,353 & 9.65 & 104,911 \\
\hline
\end{tabular}




\begin{tabular}{|c|c|c|c|c|c|c|c|}
\hline Sector & Fuel & Abatement & $\begin{array}{r}\text { Replacing (\% of activity } \\
\text { data) }\end{array}$ & $\begin{array}{r}\text { Unit cost, } \\
\text { EUR/t } \text { PM }_{2.5}\end{array}$ & $\begin{array}{r}\text { Marginal cost, } \\
\text { EUR/t PM } \\
\text { EN.5 }^{2}\end{array}$ & $\begin{array}{r}\text { Remaining } \\
\text { emissions, kt }\end{array}$ & $\begin{array}{r}\text { Accumulated costs, } \\
\text { th EUR }\end{array}$ \\
\hline Ploughing, tilling, harvesting & No fuel use & $\begin{array}{l}\text { Low-till farming, alternative cereal } \\
\text { harvesting }\end{array}$ & $100 \%$ No control & 334,859 & 334,859 & 9.63 & 113,724 \\
\hline Poultry & No fuel use & Feed modification (all livestock) & $100 \%$ no control & 458,546 & 458,546 & 9.60 & 124,376 \\
\hline Other cattle & No fuel use & Feed modification (all livestock) & $100 \%$ no control & 458,546 & 458,546 & 9.60 & 127,259 \\
\hline Dairy cattle & No fuel use & Feed modification (all livestock) & $100 \%$ No control & 458,546 & 458,546 & 9.59 & 128,268 \\
\hline Pigs & No fuel use & Feed modification (all livestock) & $100 \%$ No control & 580,724 & 580,724 & 9.58 & 134,433 \\
\hline Construction activities & No fuel use & Spraying water at construction places & $100 \%$ No control & 824,004 & 824,004 & 9.58 & 139,216 \\
\hline
\end{tabular}




\section{Annex 5. Black carbon cost curve for stationary emission sources in Belarus - specification of measures}

Measures below illustrate the cost curve approach to choosing the most cost-effective measures for a certain ambition level regarding $B C$ emission reductions. Measures should be applied in a given order, replacing already applied less efficient measures, until the target emission level ("remaining emissions") is achieved.

\begin{tabular}{|c|c|c|c|c|c|c|c|}
\hline Sector & Fuel & Abatement & $\begin{array}{r}\text { Replacing (\% of activity } \\
\text { data) }\end{array}$ & $\begin{array}{l}\text { Unit cost, } \\
\text { EUR/t BC }\end{array}$ & $\begin{array}{r}\text { Marginal cost, } \\
\text { EUR/t BC }\end{array}$ & $\begin{array}{r}\text { Remaining } \\
\text { emissions, kt }\end{array}$ & $\begin{array}{l}\text { Accumulated } \\
\text { costs, th EUR }\end{array}$ \\
\hline Cement production & No fuel use & Electrostatic precipitator: 1 field & $0.81 \%$ cyclone & 35,781 & 8,893 & 2.615 & 16 \\
\hline Flaring in gas \& oil industry & No fuel use & $\begin{array}{l}\text { Good practice in oil and gas industry- } \\
\text { flaring }\end{array}$ & $100 \%$ no control & 15,523 & 15,523 & 2.593 & 365 \\
\hline Industrial furnaces & Biomass fuels & Electrostatic precipitator: 1 field & $90 \%$ no control & 17,267 & 17,267 & 2.350 & 4,563 \\
\hline Single house boilers ( $<50 \mathrm{~kW})$ - manual & Hard coal, grade 1 & Coal single house boiler new & go no control & 28,278 & 28,278 & 2.349 & 4,570 \\
\hline Medium boilers ( $<1 \mathrm{MW})$ - manual & Fuelwood & High efficiency deduster & $90 \%$ cyclone & 54,406 & 32,148 & 2.143 & 11,217 \\
\hline $\begin{array}{l}\text { Power \& district heat plants - existing } \\
\text { (excl. coal) }\end{array}$ & Biomass fuels & Electrostatic precipitator: 1 field & $40 \%$ cyclone & 66,795 & 38,202 & 2.141 & 11,280 \\
\hline Medium boilers ( $<50 \mathrm{MW}$ ) - automatic & Fuelwood & High efficiency deduster & $90 \%$ cyclone & 69,314 & 40,557 & 2.100 & 12,957 \\
\hline Single house boilers $(<50 \mathrm{~kW})$ - manual & Fuelwood & Biomass single house boiler new & $90 \%$ improved & 48,756 & 47,836 & 2.052 & 15,235 \\
\hline Single house boilers $(<50 \mathrm{~kW})$ - manual & Fuelwood & Biomass single house boiler improved & $90 \%$ no control & 49,355 & 49,355 & 1.979 & 18,852 \\
\hline $\begin{array}{l}\text { Power \& district heat plants - existing } \\
\text { coal (<50 MWth) }\end{array}$ & $\begin{array}{l}\text { Brown coal/lignite grade } 2 \\
\text { (also peat) }\end{array}$ & Electrostatic precipitator: 1 field & $40 \%$ cyclone & 125,101 & $53,55^{8}$ & 1.978 & 18,905 \\
\hline $\begin{array}{l}\text { Power \& district heat plants - new (excl. } \\
\text { coal) }\end{array}$ & Heavy fuel oil & High efficiency deduster & $90 \%$ good practice & 82,316 & 71,278 & 1.976 & 19,052 \\
\hline Industrial furnaces & Biomass fuels & High efficiency deduster & $90 \% \mathrm{ESP}_{1}$ & 22,434 & 75,450 & 1.952 & 20,840 \\
\hline
\end{tabular}




\begin{tabular}{|c|c|c|c|c|c|c|c|}
\hline Sector & Fuel & Abatement & $\begin{array}{r}\text { Replacing (\% of activity } \\
\text { data) }\end{array}$ & $\begin{array}{l}\text { Unit cost, } \\
\text { EUR/t BC }\end{array}$ & $\begin{array}{r}\text { Marginal cost, } \\
\text { EUR/t BC }\end{array}$ & $\begin{array}{r}\text { Remaining } \\
\text { emissions, kt }\end{array}$ & $\begin{array}{l}\text { Accumulated } \\
\text { costs, th EUR }\end{array}$ \\
\hline $\begin{array}{l}\text { Power \& district heat plants - existing } \\
\text { (excl. coal) }\end{array}$ & Heavy fuel oil & High efficiency deduster & $90 \%$ good practice & 97,319 & 84,228 & 1.947 & 21,290 \\
\hline Single house boilers $(<50 \mathrm{~kW})$ - manual & Fuelwood & $\begin{array}{l}\text { Biomass single house boiler - pellets and } \\
\text { electrostatic precipitator }\end{array}$ & $90 \%$ new & 58,150 & 102,487 & 1.921 & 23,915 \\
\hline Medium boilers $(<50 \mathrm{OMW})$ - automatic & Hard coal, grade 1 & High efficiency deduster & $90 \%$ no control & 104,621 & 104,621 & 1.921 & 23,916 \\
\hline Lime production & No fuel use & High efficiency deduster & $60 \% \mathrm{ESP}_{2}$ & 67,972 & 140,911 & 1.919 & 24,242 \\
\hline Single house boilers $(<50 \mathrm{~kW})$ - manual & $\begin{array}{l}\text { Brown coal/lignite grade } 2 \\
\text { (also peat) }\end{array}$ & Coal single house boiler new & 90 \% no control & 143,706 & 143,706 & 1.914 & 24,941 \\
\hline Industrial furnaces & Heavy fuel oil & High efficiency deduster & $90 \%$ good practice & 175,135 & 162,139 & 1.899 & 27,417 \\
\hline Industrial furnaces & $\begin{array}{l}\text { Other biomass and waste } \\
\text { fuels }\end{array}$ & Electrostatic precipitator: 1 field & $90 \%$ no control & 170,143 & 170,143 & 1.892 & 28,563 \\
\hline Lime production & No fuel use & Electrostatic precipitator: 2 fields & $60 \% \mathrm{ESP}_{1}$ & 63,373 & 187,864 & 1.891 & 28,780 \\
\hline $\begin{array}{l}\text { Glass production (flat, blown, container } \\
\text { glass) }\end{array}$ & No fuel use & Electrostatic precipitator: 1 field & $10 \%$ no control & 356,531 & 356,531 & 1.891 & 28,797 \\
\hline $\begin{array}{l}\text { Glass production (flat, blown, container } \\
\text { glass) }\end{array}$ & No fuel use & Electrostatic precipitator: 1 field & $50 \%$ cyclone & 356,531 & 205,368 & 1.891 & 28,800 \\
\hline Medium boilers $(<1 \mathrm{MW})$ - manual & Fuelwood & Cyclone & 90 \% no control & 234,455 & 234,455 & 1.865 & 34,793 \\
\hline Cement production & No fuel use & Electrostatic precipitator: 2 fields & $0.81 \% \mathrm{ESP}_{1}$ & 42,321 & 244,294 & 1.865 & 34,810 \\
\hline Heating stoves & Fuelwood & New stove with electrostatic precipitator & $40 \%$ improved & 335,875 & 254,432 & 1.325 & 172,105 \\
\hline Heating stoves & Fuelwood & New stove with electrostatic precipitator & $50 \%$ new & 335,875 & 254,432 & 1.160 & 214,193 \\
\hline Medium boilers $(<50 M W)$ - automatic & $\begin{array}{l}\text { Brown coal/lignite grade } 2 \\
\text { (also peat) }\end{array}$ & High efficiency deduster & $90 \%$ no control & 264,153 & 264,153 & 1.159 & 214,535 \\
\hline Industry: Other combustion, pulverized & Hard coal, grade 1 & High efficiency deduster & $80 \% \mathrm{ESP}_{1}$ & 149,130 & 269,707 & 1.156 & 215,384 \\
\hline Industry: Other combustion, pulverized & Hard coal, grade 1 & High efficiency deduster & $10 \% \mathrm{ESP}_{2}$ & 149,130 & 269,707 & 1.155 & 215,455 \\
\hline $\begin{array}{l}\text { Power \& district heat plants - new (excl. } \\
\text { coal) }\end{array}$ & Heavy fuel oil & Good housekeeping: industrial oil boilers & $40 \%$ no control & 292,000 & 292,000 & 1.155 & 215,469 \\
\hline $\begin{array}{l}\text { Power \& district heat plants - existing } \\
\text { (excl. coal) }\end{array}$ & Biomass fuels & High efficiency deduster & $80 \% \mathrm{ESP}_{1}$ & 87,668 & 301,802 & 1.155 & 215,580 \\
\hline
\end{tabular}




\begin{tabular}{|c|c|c|c|c|c|c|c|}
\hline Sector & Fuel & Abatement & $\begin{array}{r}\text { Replacing (\% of activity } \\
\text { data) }\end{array}$ & $\begin{array}{l}\text { Unit cost, } \\
\text { EUR/t BC }\end{array}$ & $\begin{array}{l}\text { Marginal cost, } \\
\text { EUR/t BC }\end{array}$ & $\begin{array}{r}\text { Remaining } \\
\text { emissions, kt }\end{array}$ & $\begin{array}{l}\text { Accumulated } \\
\text { costs, th EUR }\end{array}$ \\
\hline $\begin{array}{l}\text { Power \& district heat plants - existing } \\
\text { (excl. coal) }\end{array}$ & Biomass fuels & High efficiency deduster & $10 \% \mathrm{ESP}_{2}$ & 87,668 & 301,802 & 1.151 & 216,679 \\
\hline Medium boilers ( $<50 \mathrm{MW})$ - automatic & Fuelwood & Cyclone & $90 \%$ no control & 301,932 & 301,932 & 1.146 & 218,222 \\
\hline $\begin{array}{l}\text { Power \& district heat plants - existing } \\
\text { coal (<50 MWth) }\end{array}$ & $\begin{array}{l}\text { Brown coal/lignite grade } 2 \\
\text { (also peat) }\end{array}$ & High efficiency deduster & $80 \% \mathrm{ESP}_{1}$ & 141,228 & 306,682 & 1.146 & 218,290 \\
\hline $\begin{array}{l}\text { Power \& district heat plants - existing } \\
\text { (excl. coal) }\end{array}$ & Heavy fuel oil & Good housekeeping: industrial oil boilers & $50 \%$ no control & 346,000 & 346,000 & 1.146 & 218,344 \\
\hline Industrial furnaces & Heavy fuel oil & Good housekeeping: industrial oil boilers & $90 \%$ no control & 422,000 & 422,000 & 1.145 & 218,683 \\
\hline Residential-commercial & Heavy fuel oil & Good housekeeping: domestic oil boilers & $90 \%$ no control & 671,714 & 671,714 & 1.145 & 218,738 \\
\hline Heating stoves & Hard coal, grade 1 & Improved stove - coal & $90 \%$ no control & 685,315 & 685,315 & 1.145 & 218,786 \\
\hline Heating stoves & Fuelwood & Pellet stove with electrostatic precipitator & $90 \%$ new with ESP & 360,794 & 737,069 & 1.060 & 281,390 \\
\hline Industrial furnaces & $\begin{array}{l}\text { Other biomass and waste } \\
\text { fuels }\end{array}$ & High efficiency deduster & $90 \% \mathrm{ESP}_{1}$ & 221,844 & 752,252 & 1.059 & 281,884 \\
\hline Cement production & No fuel use & High efficiency deduster & $6.24 \% \mathrm{ESP}_{2}$ & 95,152 & 933,052 & 1.058 & 282,869 \\
\hline Heating stoves & $\begin{array}{l}\text { Brown coal/lignite grade } 2 \\
\text { (also peat) }\end{array}$ & Improved stove - coal & $90 \%$ no control & $1,187,889$ & $1,187,889$ & 1.002 & 349,154 \\
\hline Medium boilers (<1MW) - manual & Hard coal, grade 1 & Cyclone & $90 \%$ no control & $1,271,818$ & $1,271,818$ & 1.002 & 349,154 \\
\hline Fireplaces & Fuelwood & New fireplace & $90 \%$ improved & $2,325,847$ & $1,355,110$ & 0.996 & 358,258 \\
\hline Heating stoves & Hard coal, grade 1 & New stove - coal & $90 \%$ improved & $1,056,735$ & $1,428,154$ & 0.996 & 358,359 \\
\hline $\begin{array}{l}\text { Glass production (flat, blown, container } \\
\text { glass) }\end{array}$ & No fuel use & High efficiency deduster & $90 \% \mathrm{ESP}_{1}$ & 456,291 & $1,479,730$ & 0.996 & 358,421 \\
\hline Heating stoves & Fuelwood & Improved stove- biomass & $40 \%$ no control & $1,781,820$ & $1,781,820$ & 0.965 & 412,577 \\
\hline $\begin{array}{l}\text { Glass production (flat, blown, container } \\
\text { glass) }\end{array}$ & No fuel use & Electrostatic precipitator: 2 fields & $10 \% \mathrm{ESP}_{1}$ & 418,926 & $2,345,763$ & 0.965 & 412,581 \\
\hline Heating stoves & $\begin{array}{l}\text { Brown coal/lignite grade } 2 \\
\text { (also peat) }\end{array}$ & New stove - coal & $90 \%$ improved & $1,831,672$ & $2,475,456$ & 0.909 & 550,713 \\
\hline
\end{tabular}




\begin{tabular}{|c|c|c|c|c|c|c|c|}
\hline Sector & Fuel & Abatement & $\begin{array}{r}\text { Replacing (\% of activity } \\
\text { data) }\end{array}$ & $\begin{array}{l}\text { Unit cost, } \\
\text { EUR/t BC }\end{array}$ & $\begin{array}{r}\text { Marginal cost, } \\
\text { EUR/t BC }\end{array}$ & $\begin{array}{r}\text { Remaining } \\
\text { emissions, kt }\end{array}$ & $\begin{array}{l}\text { Accumulated } \\
\text { costs, th EUR }\end{array}$ \\
\hline Medium boilers $(<1 \mathrm{MW})$ - manual & $\begin{array}{l}\text { Brown coal/lignite grade } 2 \\
\text { (also peat) }\end{array}$ & Cyclone & $90 \%$ no control & $3,140,000$ & $3,140,000$ & 0.909 & 550,776 \\
\hline Residential-commercial & Diesel & Good housekeeping: domestic oil boilers & $90 \%$ no control & $4,702,000$ & $4,702,000$ & 0.909 & 550,780 \\
\hline Fireplaces & Fuelwood & Improved fireplace & $90 \%$ no control & $6,208,791$ & $6,208,791$ & 0.908 & 561,208 \\
\hline
\end{tabular}

$94 \quad P M_{2.5}$ and $B C$ emissions in Belarus 


\section{Annex 6. Alternative emission factors sets for industrial processes in}

Belarus

Current unabated emission factors (UEF) and BC shares are country-specific; removal efficiencies (RE) and alternative (EMEP/EEA Guidebook-based) UEF are common for all countries; BC shares are technology-specific and based on "disaggregation" of the Guidebook-based averaged number by technologies/device types available in GAINS (the method is described in Chapter 4.5 ).

Table 19: Alternative emission factors sets for industrial processes in Belarus

\begin{tabular}{|c|c|c|c|c|c|c|c|c|c|}
\hline \multirow[t]{2}{*}{ Sector } & \multirow[t]{2}{*}{ Abatement technology } & \multirow{2}{*}{$\begin{array}{r}\text { Application rates, as } \\
\text { assumed in the } \\
\text { Guidebook, \% }\end{array}$} & \multicolumn{3}{|c|}{$\mathrm{PM}_{2.5}$} & \multicolumn{4}{|c|}{ BC } \\
\hline & & & $\begin{array}{r}\text { Removal } \\
\text { efficiency, \% }\end{array}$ & $\begin{array}{r}\text { Current UEF } 15, \\
\mathrm{~kg} / \mathrm{t}\end{array}$ & $\begin{array}{r}\text { Alternative } \\
\text { UEF, } \mathrm{kg} / \mathrm{t}\end{array}$ & $\begin{array}{r}\text { Removal } \\
\text { efficiency, \% }\end{array}$ & $\begin{array}{r}\text { Current UEF, } \\
\mathrm{kg} / \mathrm{t}\end{array}$ & $\begin{array}{r}\text { Alternative } \\
\text { UEF, kg/t }\end{array}$ & $B C, \%$ of $\mathrm{PM}_{2.5}$ \\
\hline \multirow{6}{*}{$\begin{array}{l}\text { Cement production (default } \mathrm{EF}=130 \mathrm{~g} \\
\mathrm{PM} 2.5 / \mathrm{t} \text { clinker, } \mathrm{BC}=3 \% \text { of } \mathrm{PM} 2.5 \text { ) }\end{array}$} & No control & o & & 23.4 & 3.714286 & & 0.03 & 0.104628 & 2.816901 \\
\hline & Cyclone & o & 30 & 16.38 & 2.6 & 11 & 0.0267 & 0.093119 & 3.581489 \\
\hline & Electrostatic precipitator: 1 field & 20 & 93 & 1.638 & 0.26 & 91.1 & 0.00267 & 0.009312 & 3.581489 \\
\hline & Electrostatic precipitator: 2 fields & 20 & 96 & 0.936 & 0.148571 & 94.05 & 0.001785 & 0.006225 & 4.190141 \\
\hline & High efficiency deduster & 60 & 99 & 0.234 & 0.037143 & 99.98 & $6 \mathrm{E}-06$ & $2.09 \mathrm{E}-05$ & 0.056338 \\
\hline & Wet scrubber & o & 93 & 1.638 & 0.26 & 91.1 & 0.00267 & 0.009312 & 3.581489 \\
\hline $\begin{array}{l}\text { Lime production (default } \mathrm{EF}=30 \mathrm{~g} \\
\mathrm{PM} 2.5 / \mathrm{t} \text { lime, } \mathrm{BC}=0.46 \% \text { of } \mathrm{PM} 2.5 \text { ) }\end{array}$ & No control & o & & 1.4 & 0.75 & & 0.05 & 0.003139 & 0.418535 \\
\hline
\end{tabular}

${ }_{15}$ Emission vector JUN2015_EU in the GAINS model. 


\begin{tabular}{|c|c|c|c|c|c|c|c|c|c|}
\hline \multirow[t]{2}{*}{ Sector } & \multirow[t]{2}{*}{ Abatement technology } & \multirow{2}{*}{$\begin{array}{r}\text { Application rates, as } \\
\text { assumed in the } \\
\text { Guidebook, \% }\end{array}$} & \multicolumn{4}{|c|}{$\mathrm{PM}_{2.5}$} & \multicolumn{3}{|c|}{ BC } \\
\hline & & & $\begin{array}{r}\text { Removal } \\
\text { efficiency, } \%\end{array}$ & $\begin{array}{r}\text { Current UEF }{ }^{16} \\
\mathrm{~kg} / \mathrm{t}\end{array}$ & $\begin{array}{r}\text { Alternative } \\
\text { UEF, kg/t }\end{array}$ & $\begin{array}{r}\text { Removal } \\
\text { efficiency, \% }\end{array}$ & $\begin{array}{r}\text { Current UEF, } \\
\mathrm{kg} / \mathrm{t}\end{array}$ & $\begin{array}{c}\text { Alternative } \\
\text { UEF, kg/t }\end{array}$ & $\mathrm{BC}, \%$ of $\mathrm{PM}_{2.5}$ \\
\hline & Electrostatic precipitator: 1 field & 50 & 93 & 0.098 & 0.0525 & 91.1 & 0.00445 & 0.000279 & 0.532138 \\
\hline & Electrostatic precipitator: 2 fields & 0 & 96 & 0.056 & 0.03 & 94.05 & 0.002975 & 0.000187 & 0.622571 \\
\hline & High efficiency deduster & 50 & 99 & 0.014 & 0.0075 & 99.98 & $1 \mathrm{E}-05$ & $6.28 \mathrm{E}-07$ & 0.008371 \\
\hline & Wet scrubber & o & 93 & 0.098 & 0.0525 & 91.1 & 0.00445 & 0.000279 & 0.532138 \\
\hline \multirow{3}{*}{$\begin{array}{l}\text { Steel production in electric arc } \\
\text { furnaces (default } E F=21 \mathrm{~g} \mathrm{PM} 2.5 / \mathrm{t} \\
\text { steel, } \mathrm{BC}=0.36 \% \text { of } \mathrm{PM} 2.5 \text { ) }\end{array}$} & No control & 0 & & 7.546 & 2.1 & & 0 & 0.38 & 18.09524 \\
\hline & Cyclone & o & 30 & 5.2822 & 1.47 & 11 & o & 0.3382 & 23.0068 \\
\hline & High efficiency deduster & 100 & 99 & 0.08 & 0.021 & 99.98 & 0 & 0.000076 & 0.361905 \\
\hline \multirow{3}{*}{$\begin{array}{l}\text { Fertilizer production (default } \mathrm{EF}=180 \\
\mathrm{~g} \mathrm{PM} 2.5 / \mathrm{t} \text { product, } \mathrm{BC}=1.8 \% \text { of } \\
\mathrm{PM} 2.5 \text { ) }\end{array}$} & No control & 40 & & 18 & 0.293638 & & 0 & 0.004857 & 1.654124 \\
\hline & Cyclone & 30 & 30 & 12.6 & 0.205546 & 11 & 0 & 0.004323 & 2.103101 \\
\hline & High efficiency deduster & 30 & 99 & 0.18 & 0.002936 & 99.98 & 0 & $9.71 \mathrm{E}-07$ & 0.033082 \\
\hline
\end{tabular}

${ }^{16}$ Emission vector JUN2015_EU in the GAINS model. 


\section{Annex 7. Emission factors for heating stoves}

Table 20: Emission factors for heating stoves

\begin{tabular}{|c|c|c|c|c|c|c|}
\hline Parameter & Country & $\begin{array}{r}\text { Conventional } \\
\text { stove }\end{array}$ & $\begin{array}{r}\text { Energy-efficient } \\
\text { (improved) } \\
\text { stove }\end{array}$ & $\begin{array}{l}\text { Advanced/ } \\
\text { ecolabelled } \\
\text { (new) stove }\end{array}$ & $\begin{array}{l}\text { Pellet } \\
\text { stove }\end{array}$ & $\begin{array}{r}\text { Pellet stove } \\
\text { with ESP }{ }^{17}\end{array}$ \\
\hline \multirow{3}{*}{$\begin{array}{l}\text { Removal } \\
\text { efficiency } \\
\text { PM2.5, \% }\end{array}$} & GAINS, Finland & & $40 \%$ & $60 \%$ & $95 \%$ & $99.25 \%$ \\
\hline & GAINS, other countries & & $63 \%$ & $80 \%$ & $95 \%$ & $99.25 \%$ \\
\hline & Guidebook & & $50 \%$ & $87 \%$ & $96 \%$ & n.a. \\
\hline \multirow[t]{3}{*}{$\begin{array}{l}\text { Removal } \\
\text { efficiency BC, \% }\end{array}$} & GAINS, Finland & & $33 \%$ & $63 \%$ & $96 \%$ & $99.98 \%$ \\
\hline & GAINS, other countries & & $5 \%$ & $72 \%$ & $96 \%$ & $99.98 \%$ \\
\hline & Guidebook & & $20 \%$ & $65 \%$ & $94 \%$ & n.a. \\
\hline \multirow{4}{*}{$\begin{array}{l}\text { Current EF } \\
P M 2.5, g / G J\end{array}$} & Belarus & 651 & 241 & 130 & 33 & 4.9 \\
\hline & Denmark & 810 & 300 & 162 & 41 & 6.1 \\
\hline & Finland & 200 & 120 & 80 & 10 & 1.5 \\
\hline & Sweden & 316 & 117 & 63 & 16 & 2.4 \\
\hline $\begin{array}{l}\text { Alternative } E F \\
P M 2.5, \mathrm{~g} / G J\end{array}$ & Guidebook & 740 & 370 & 93 & 29 & 5.5 \\
\hline \multirow{4}{*}{$\begin{array}{l}\text { Current share of } \\
\mathrm{BC} \text { in PM.2.5, \% }\end{array}$} & Belarus & $15 \%$ & $39 \%$ & $22 \%$ & $12 \%$ & $0.4 \%$ \\
\hline & Denmark & $12 \%$ & $32 \%$ & $17 \%$ & $10 \%$ & $0.3 \%$ \\
\hline & Finland & $40 \%$ & $44 \%$ & $37 \%$ & $32 \%$ & $1 \%$ \\
\hline & Sweden & $22 \%$ & $55 \%$ & $30 \%$ & $17 \%$ & $1 \%$ \\
\hline $\begin{array}{l}\text { Alternative } \\
\text { share of } B C \text { in } \\
\text { PM. } 2.5, \%\end{array}$ & Guidebook & $10 \%$ & $16 \%$ & $28 \%$ & $15 \%$ & n.a. \\
\hline $\begin{array}{l}\text { Current EF BC, } \\
\text { g/GJ }\end{array}$ & Belarus & 100 & 95 & 28 & 4.1 & 0.02 \\
\hline
\end{tabular}

${ }_{17}$ This category is not present in the EMEP/EEA Guidebook. To derive alternative emission factors, the GAINS-based ratio of removal efficiencies of "pellet stove" and "pellet stove with ESP" (compared to a conventional stove) is applied to alternative emission factors for the "pellet stove" category. 


\begin{tabular}{|c|c|c|c|c|c|c|}
\hline Parameter & & $\begin{array}{r}\text { Conventional } \\
\text { stove }\end{array}$ & $\begin{array}{r}\text { Energy-efficient } \\
\text { (improved) } \\
\text { stove }\end{array}$ & $\begin{array}{r}\text { Advanced/ } \\
\text { ecolabelled } \\
\text { (new) stove }\end{array}$ & $\begin{array}{l}\text { Pellet } \\
\text { stove }\end{array}$ & $\begin{array}{r}\text { Pellet stove } \\
\text { with ESP }\end{array}$ \\
\hline & Denmark & 100 & 95 & 28 & 4.1 & 0.02 \\
\hline & Finland & 79 & 53 & 29 & 3.2 & 0.02 \\
\hline & Sweden & 68 & 65 & 19 & 2.8 & 0.01 \\
\hline $\begin{array}{l}\text { Alternative } E F \\
B C, g / G J\end{array}$ & Guidebook & 74 & 59 & 26 & 4.4 & 0.01 \\
\hline
\end{tabular}




\section{Annex 8. Baseline emissions and emission reduction potentials in the Nordic countries in 2030}

Figure 34: Baseline emissions and emission reduction potentials in the Nordic countries in 2030. $\mathrm{PM}_{2.5}$ ktonnes
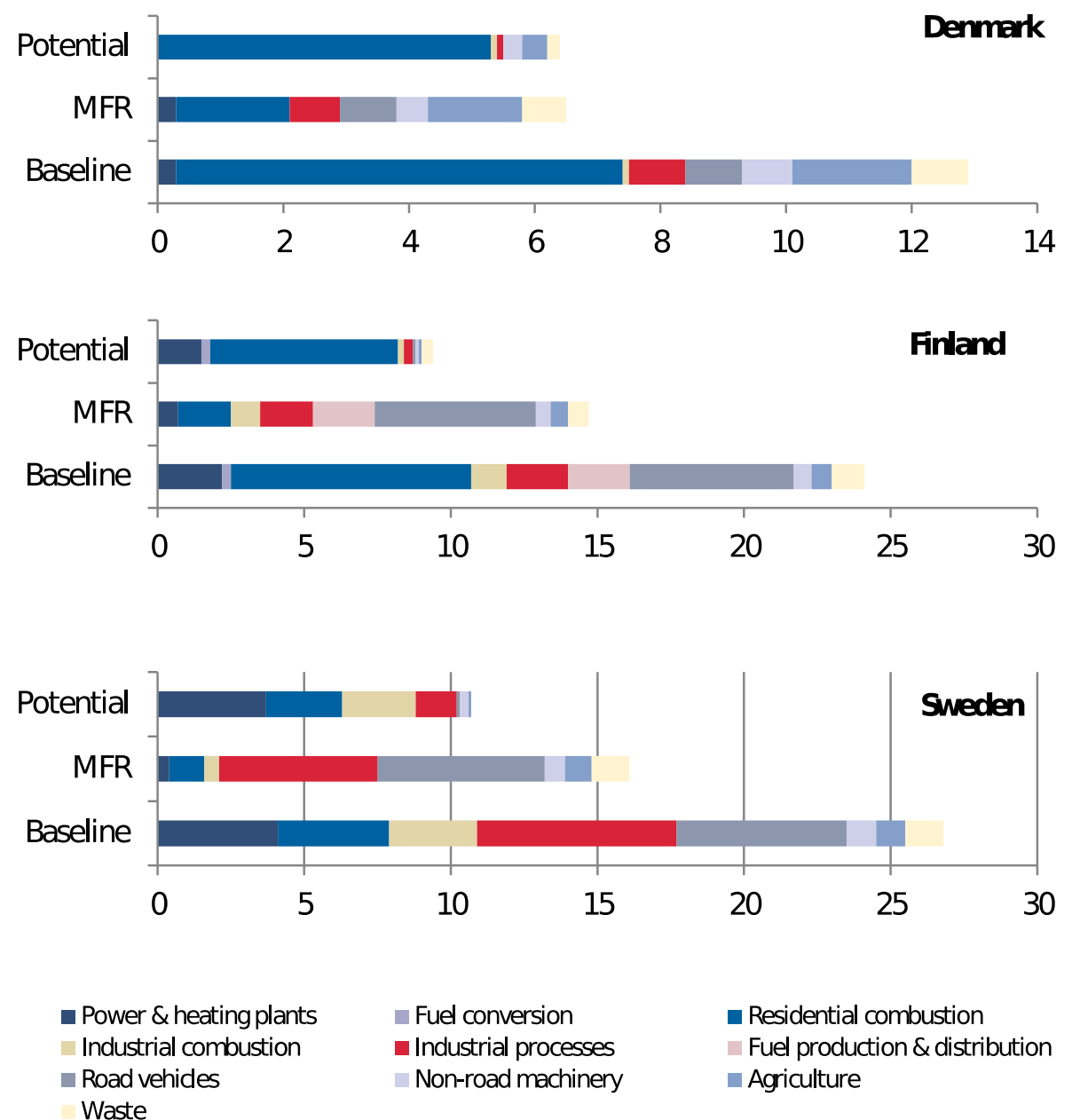
Waste 
Figure35: Baseline emissions and emission reduction potentials in the Nordic countries in 2030 . BC, ktonnes
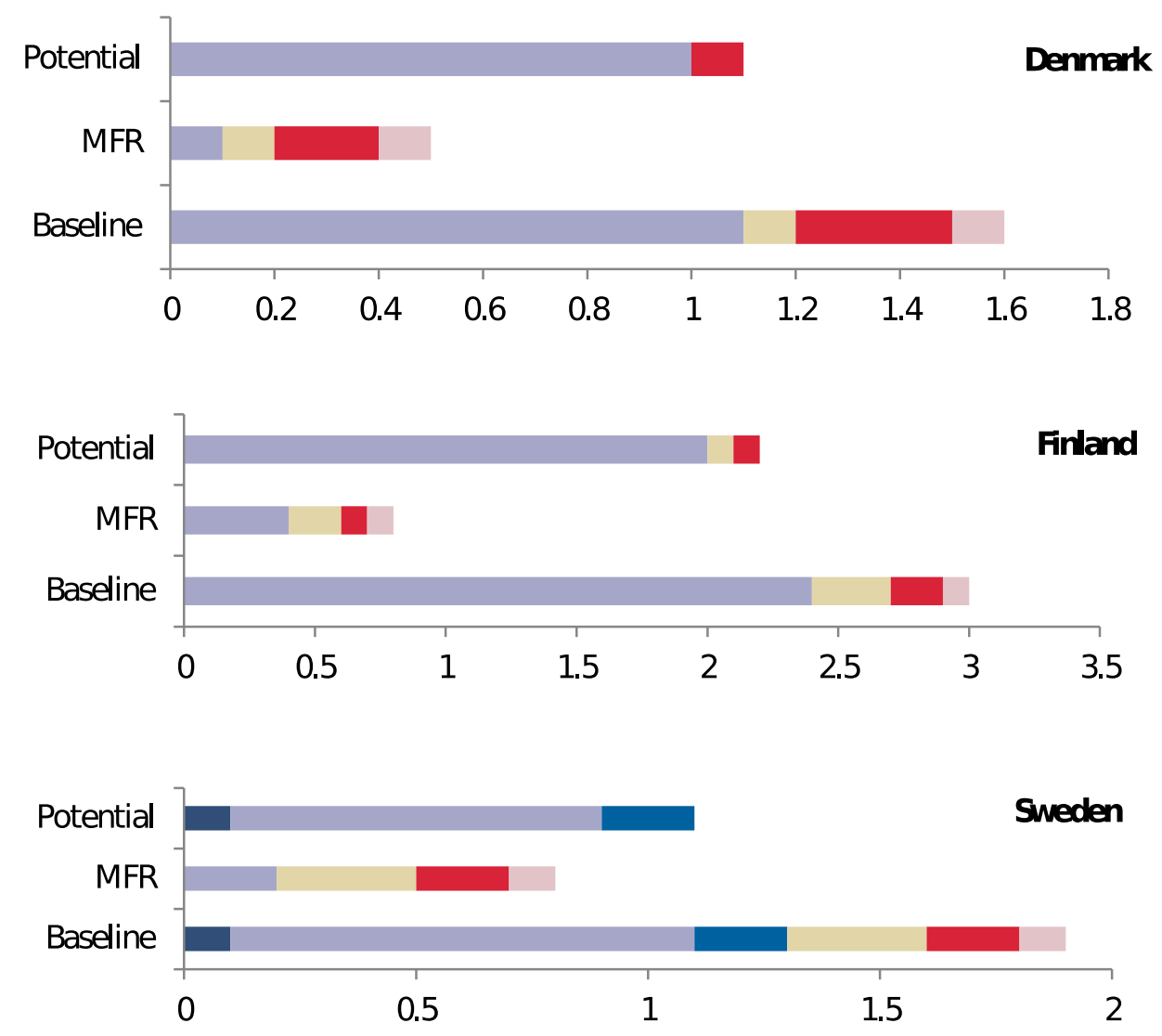

- Power \& heating plants — Residential combustion — Industrial combustion

Road vehicles $\quad$ Non-road machinery $\quad$ Waste 


\section{Annex 9. Ranking of black carbon reduction measures for stationary emission sources by marginal costs, the Nordic countries}

Measures below illustrate ranking of cost-effective measures available for $\mathrm{BC}$ according to the GAINS model. Applying measures in a given order would assure the most costeffective approach to "closing the gap" between the baseline and MFR scenarios.

Table 21: Ranking of BC emission reduction measures (stationary sources) - Denmark

\begin{tabular}{|c|c|c|c|c|c|}
\hline Sector & Fuel & Abatement & $\begin{array}{r}\text { Replacing (\% of } \\
\text { activity data) }\end{array}$ & $\begin{array}{l}\text { Unit cost, } \\
\text { EUR/t BC }\end{array}$ & $\begin{array}{r}\text { Marginal cost, } \\
\text { EUR/t BC }\end{array}$ \\
\hline $\begin{array}{l}\text { Agricultural waste } \\
\text { burning }\end{array}$ & No fuel use & $\begin{array}{l}\text { Ban on open } \\
\text { burning }\end{array}$ & $100 \%$ no control & 786 & 786 \\
\hline Trash burning & No fuel use & $\begin{array}{l}\text { Ban on open } \\
\text { burning }\end{array}$ & $100 \%$ no control & 1,063 & 1,063 \\
\hline $\begin{array}{l}\text { Meat frying, food } \\
\text { preparation, } B B O\end{array}$ & No fuel use & $\begin{array}{l}\text { Filters in } \\
\text { households } \\
\text { (kitchen) }\end{array}$ & $100 \%$ no control & 9,100 & 9,100 \\
\hline $\begin{array}{l}\text { Medium boilers } \\
(<1 \mathrm{MW}) \text { - manual }\end{array}$ & Fuelwood & Pellet boiler & $100 \%$ no control & 10,882 & 10,882 \\
\hline $\begin{array}{l}\text { Chemical industry } \\
\text { (boilers) }\end{array}$ & Biomass fuels & $\begin{array}{l}\text { Electrostatic } \\
\text { precipitator: } 1 \text { field }\end{array}$ & $5 \%$ cyclone & 20,955 & 12,684 \\
\hline $\begin{array}{l}\text { Other industry } \\
\text { (boilers; liquid and } \\
\text { gaseous fuels) }\end{array}$ & Biomass fuels & $\begin{array}{l}\text { Electrostatic } \\
\text { precipitator: } 1 \text { field }\end{array}$ & $5 \%$ cyclone & 20,955 & 12,684 \\
\hline $\begin{array}{l}\text { Paper \& pulp } \\
\text { (boilers) }\end{array}$ & Biomass fuels & $\begin{array}{l}\text { Electrostatic } \\
\text { precipitator: } 1 \text { field }\end{array}$ & $5 \%$ cyclone & 20,955 & 12,684 \\
\hline Heating stoves & Hard coal, grade 1 & Briquette stove & $40 \%$ no control & 20,191 & 20,191 \\
\hline $\begin{array}{l}\text { Medium boilers } \\
(<50 \mathrm{MW})- \\
\text { automatic }\end{array}$ & Fuelwood & Pellet boiler & $100 \%$ no control & 27,205 & 27,205 \\
\hline Industrial furnaces & Biomass fuels & $\begin{array}{l}\text { High efficiency } \\
\text { deduster }\end{array}$ & $100 \% \mathrm{ESP} 2$ & 17,493 & 37,943 \\
\hline $\begin{array}{l}\text { Medium boilers } \\
(<50 M W)- \\
\text { automatic }\end{array}$ & Hard coal, grade 1 & $\begin{array}{l}\text { High efficiency } \\
\text { deduster }\end{array}$ & $60 \%$ cyclone & 80,016 & 51,978 \\
\hline $\begin{array}{l}\text { Medium boilers } \\
(<50 \mathrm{MW})- \\
\text { automatic }\end{array}$ & Hard coal, grade 1 & $\begin{array}{l}\text { High efficiency } \\
\text { deduster }\end{array}$ & $40 \%$ no control & 80,016 & 80,016 \\
\hline
\end{tabular}




\begin{tabular}{|c|c|c|c|c|c|}
\hline Sector & Fuel & Abatement & $\begin{array}{r}\text { Replacing ( } \% \text { of } \\
\text { activity data) }\end{array}$ & $\begin{array}{l}\text { Unit cost, } \\
\text { EUR/t BC }\end{array}$ & $\begin{array}{r}\text { Marginal cost, } \\
\text { EUR/t BC }\end{array}$ \\
\hline $\begin{array}{l}\text { Chemical industry } \\
\text { (boilers) }\end{array}$ & Biomass fuels & $\begin{array}{l}\text { High efficiency } \\
\text { deduster }\end{array}$ & $5 \% \mathrm{ESP}_{1}$ & 26,785 & 86,599 \\
\hline $\begin{array}{l}\text { Other industry } \\
\text { (boilers; liquid and } \\
\text { gaseous fuels) }\end{array}$ & Biomass fuels & $\begin{array}{l}\text { High efficiency } \\
\text { deduster }\end{array}$ & $5 \% \mathrm{ESP}_{1}$ & 26,785 & 86,599 \\
\hline $\begin{array}{l}\text { Paper \& pulp } \\
\text { (boilers) }\end{array}$ & Biomass fuels & $\begin{array}{l}\text { High efficiency } \\
\text { deduster }\end{array}$ & $5 \% \mathrm{ESP}_{1}$ & 26,785 & 86,599 \\
\hline $\begin{array}{l}\text { Fuel conversion - } \\
\text { combustion }\end{array}$ & Heavy fuel oil & $\begin{array}{l}\text { High efficiency } \\
\text { deduster }\end{array}$ & $\begin{array}{r}100 \% \text { good } \\
\text { practice }\end{array}$ & 137,928 & 129,185 \\
\hline Industrial furnaces & Heavy fuel oil & $\begin{array}{l}\text { High efficiency } \\
\text { deduster }\end{array}$ & $\begin{array}{r}100 \% \text { good } \\
\text { practice }\end{array}$ & 137,928 & 129,185 \\
\hline $\begin{array}{l}\text { Power \& district } \\
\text { heat plants - } \\
\text { existing coal }(<50 \\
\text { MWth) }\end{array}$ & Hard coal, grade 1 & $\begin{array}{l}\text { High efficiency } \\
\text { deduster }\end{array}$ & $40 \% \mathrm{ESP}_{2}$ & 51,194 & 140,766 \\
\hline $\begin{array}{l}\text { Power \& district } \\
\text { heat plants - new } \\
\text { (excl. coal) }\end{array}$ & $\begin{array}{l}\text { Other biomass and } \\
\text { waste fuels }\end{array}$ & $\begin{array}{l}\text { High efficiency } \\
\text { deduster }\end{array}$ & $40 \% \mathrm{ESP}_{2}$ & 90,518 & 195,616 \\
\hline Heating stoves & Fuelwood & Pellet stove & $30 \%$ new & 224,498 & 69,206 \\
\hline Heating stoves & Fuelwood & Pellet stove & $70 \%$ Improved & 224,498 & 208,457 \\
\hline $\begin{array}{l}\text { Transformation } \\
\text { sector (boilers) }\end{array}$ & Heavy fuel oil & $\begin{array}{l}\text { High efficiency } \\
\text { deduster }\end{array}$ & $\begin{array}{r}100 \% \text { good } \\
\text { practice }\end{array}$ & 238,848 & 225,626 \\
\hline $\begin{array}{l}\text { Other industry } \\
\text { (boilers; liquid and } \\
\text { gaseous fuels) }\end{array}$ & Heavy fuel oil & $\begin{array}{l}\text { High efficiency } \\
\text { deduster }\end{array}$ & $\begin{array}{r}100 \% \text { good } \\
\text { practice }\end{array}$ & 238,848 & 225,626 \\
\hline $\begin{array}{l}\text { Paper \& pulp } \\
\text { (boilers) }\end{array}$ & Heavy fuel oil & $\begin{array}{l}\text { High efficiency } \\
\text { deduster }\end{array}$ & $\begin{array}{r}100 \% \text { good } \\
\text { practice }\end{array}$ & 238,848 & 225,626 \\
\hline $\begin{array}{l}\text { Power \& district } \\
\text { heat plants - new } \\
\text { (excl. coal) }\end{array}$ & Heavy fuel oil & $\begin{array}{l}\text { High efficiency } \\
\text { deduster }\end{array}$ & $28 \%$ good practice & 268,654 & 228,996 \\
\hline $\begin{array}{l}\text { Medium boilers } \\
(<50 \mathrm{MW})- \\
\text { automatic }\end{array}$ & Fuelwood & $\begin{array}{l}\text { High efficiency } \\
\text { deduster }\end{array}$ & $100 \%$ pellet boiler & 51,385 & 247,382 \\
\hline $\begin{array}{l}\text { Power \& district } \\
\text { heat plants - new } \\
\text { coal (>50 MWth) }\end{array}$ & Hard coal, grade 1 & $\begin{array}{l}\text { High efficiency } \\
\text { deduster }\end{array}$ & $5 \% \mathrm{ESP}_{2}$ & 208,142 & 263,069 \\
\hline $\begin{array}{l}\text { Industry: Other } \\
\text { combustion, } \\
\text { pulverized }\end{array}$ & Hard coal, grade 1 & $\begin{array}{l}\text { High efficiency } \\
\text { deduster }\end{array}$ & $100 \% \mathrm{ESP}_{2}$ & 211,442 & 274,874 \\
\hline $\begin{array}{l}\text { Medium boilers } \\
(<1 \mathrm{MW})-\text { manual }\end{array}$ & Fuelwood & $\begin{array}{l}\text { High efficiency } \\
\text { deduster }\end{array}$ & $100 \%$ pellet boiler & 40,028 & 276,275 \\
\hline $\begin{array}{l}\text { Power \& district } \\
\text { heat plants - } \\
\text { existing coal (>50 } \\
\text { MWth) }\end{array}$ & Hard coal, grade 1 & $\begin{array}{l}\text { High efficiency } \\
\text { deduster }\end{array}$ & $5 \% \mathrm{ESP}_{2}$ & 232,146 & 327,150 \\
\hline
\end{tabular}




\begin{tabular}{|c|c|c|c|c|c|}
\hline Sector & Fuel & Abatement & $\begin{array}{r}\text { Replacing (\% of } \\
\text { activity data) }\end{array}$ & $\begin{array}{l}\text { Unit cost, } \\
\text { EUR/t BC }\end{array}$ & $\begin{array}{r}\text { Marginal cost, } \\
\text { EUR/t BC }\end{array}$ \\
\hline $\begin{array}{l}\text { Power \& district } \\
\text { heat plants - } \\
\text { existing (excl. coal) }\end{array}$ & Heavy fuel oil & $\begin{array}{l}\text { High efficiency } \\
\text { deduster }\end{array}$ & $58 \%$ good practice & 468,494 & 397,452 \\
\hline $\begin{array}{l}\text { Other industry } \\
\text { (large coal boilers; } \\
\text { > } 50 \mathrm{MWth} \text { ) }\end{array}$ & Hard coal, grade 1 & $\begin{array}{l}\text { High efficiency } \\
\text { deduster }\end{array}$ & $100 \% \mathrm{ESP}_{2}$ & 270,754 & 416,526 \\
\hline Heating stoves & Fuelwood & $\begin{array}{l}\text { Improved stove - } \\
\text { biomass }\end{array}$ & $35 \%$ no control & 516,240 & 516,240 \\
\hline Fireplaces & Fuelwood & Improved fireplace & $100 \%$ no control & 651,280 & 651,280 \\
\hline Fireplaces & Fuelwood & New fireplace & $40 \%$ improved & 987,564 & $1,071,635$ \\
\hline Heating stoves & Hard coal, grade 1 & New stove - coal & $40 \%$ Improved & 764,673 & $1,330,792$ \\
\hline
\end{tabular}

Table 22: Ranking of BC emission reduction measures (stationary sources) - Finland

\begin{tabular}{|c|c|c|c|c|c|}
\hline Sector & Fuel & Abatement & $\begin{array}{l}\text { Replacing (\% of } \\
\text { activity data) }\end{array}$ & $\begin{array}{l}\text { Unit cost, } \\
\text { EUR/t BC }\end{array}$ & $\begin{array}{r}\text { Marginal cost, } \\
\text { EUR/t BC }\end{array}$ \\
\hline $\begin{array}{l}\text { Agricultural waste } \\
\text { burning }\end{array}$ & No fuel use & $\begin{array}{l}\text { Ban on open } \\
\text { burning }\end{array}$ & $100 \%$ no control & 435 & 435 \\
\hline Trash burning & No fuel use & $\begin{array}{l}\text { Ban on open } \\
\text { burning }\end{array}$ & $100 \%$ no control & 1,240 & 1,240 \\
\hline $\begin{array}{l}\text { Fuel conversion - } \\
\text { combustion }\end{array}$ & $\begin{array}{l}\text { Other biomass and } \\
\text { waste fuels }\end{array}$ & $\begin{array}{l}\text { Electrostatic } \\
\text { precipitator: } 1 \text { field }\end{array}$ & $100 \%$ cyclone & 6,111 & 2,408 \\
\hline $\begin{array}{l}\text { Single house } \\
\text { boilers }(<50 \mathrm{~kW})- \\
\text { manual }\end{array}$ & Fuelwood & $\begin{array}{l}\text { Biomass single } \\
\text { house boiler } \\
\text { improved }\end{array}$ & $19 \%$ no control & 6,548 & 6,548 \\
\hline $\begin{array}{l}\text { Meat frying, food } \\
\text { preparation, } \mathrm{BBO}\end{array}$ & No fuel use & $\begin{array}{l}\text { Filters in } \\
\text { households } \\
\text { (kitchen) }\end{array}$ & $100 \%$ no control & 9,100 & 9,100 \\
\hline $\begin{array}{l}\text { Medium boilers } \\
\text { (<1MW) - manual }\end{array}$ & Fuelwood & Pellet boiler & $100 \%$ no control & 10,882 & 10,882 \\
\hline $\begin{array}{l}\text { Fuel conversion - } \\
\text { combustion }\end{array}$ & $\begin{array}{l}\text { Other biomass and } \\
\text { waste fuels }\end{array}$ & $\begin{array}{l}\text { High efficiency } \\
\text { deduster }\end{array}$ & $100 \% \mathrm{ESP}_{1}$ & 6,918 & 15,203 \\
\hline Industrial furnaces & Biomass fuels & $\begin{array}{l}\text { High efficiency } \\
\text { deduster }\end{array}$ & $84 \% \mathrm{ESP} 2$ & 14,428 & 33,305 \\
\hline Industrial furnaces & Biomass fuels & $\begin{array}{l}\text { High efficiency } \\
\text { deduster }\end{array}$ & $16 \% \mathrm{ESP}_{1}$ & 14,428 & 47,016 \\
\hline $\begin{array}{l}\text { Single house } \\
\text { boilers }(<50 \mathrm{~kW})- \\
\text { manual }\end{array}$ & Fuelwood & $\begin{array}{l}\text { Biomass single } \\
\text { house boiler - } \\
\text { pellets }\end{array}$ & $78 \%$ improved & 11,907 & 53,989 \\
\hline $\begin{array}{l}\text { Fuel conversion - } \\
\text { combustion }\end{array}$ & Heavy fuel oil & $\begin{array}{l}\text { High efficiency } \\
\text { deduster }\end{array}$ & $100 \% \mathrm{GP}$ & 70,414 & 63,803 \\
\hline $\begin{array}{l}\text { Chemical industry } \\
\text { (boilers) }\end{array}$ & Heavy fuel oil & $\begin{array}{l}\text { High efficiency } \\
\text { deduster }\end{array}$ & $28 \% \mathrm{GP}$ & 73,081 & 70,050 \\
\hline
\end{tabular}




\begin{tabular}{|c|c|c|c|c|c|}
\hline Sector & Fuel & Abatement & $\begin{array}{r}\text { Replacing ( } \% \text { of } \\
\text { activity data) }\end{array}$ & $\begin{array}{l}\text { Unit cost, } \\
\text { EUR/t BC }\end{array}$ & $\begin{array}{r}\text { Marginal cost, } \\
\text { EUR/t BC }\end{array}$ \\
\hline $\begin{array}{l}\text { Transformation } \\
\text { sector (boilers) }\end{array}$ & Heavy fuel oil & $\begin{array}{l}\text { High efficiency } \\
\text { deduster }\end{array}$ & $28 \% \mathrm{GP}$ & 73,081 & 70,050 \\
\hline $\begin{array}{l}\text { Other industry } \\
\text { (boilers; liquid and } \\
\text { gaseous fuels) }\end{array}$ & Heavy fuel oil & $\begin{array}{l}\text { High efficiency } \\
\text { deduster }\end{array}$ & $28 \%$ GP & 73,081 & 70,050 \\
\hline $\begin{array}{l}\text { Paper \& pulp } \\
\text { (boilers) }\end{array}$ & Heavy fuel oil & $\begin{array}{l}\text { High efficiency } \\
\text { deduster }\end{array}$ & $28 \%$ GP & 73,081 & 70,050 \\
\hline $\begin{array}{l}\text { Medium boilers } \\
(<50 \mathrm{MW})- \\
\text { automatic }\end{array}$ & Hard coal, grade 1 & $\begin{array}{l}\text { High efficiency } \\
\text { deduster }\end{array}$ & $60 \%$ cyclone & 76,040 & 50,826 \\
\hline $\begin{array}{l}\text { Medium boilers } \\
(<50 \mathrm{MW})- \\
\text { automatic }\end{array}$ & Hard coal, grade 1 & $\begin{array}{l}\text { High efficiency } \\
\text { deduster }\end{array}$ & $40 \%$ no control & 76,040 & 76,040 \\
\hline $\begin{array}{l}\text { Pig iron, blast } \\
\text { furnace }\end{array}$ & No fuel use & $\begin{array}{l}\text { High efficiency } \\
\text { deduster }\end{array}$ & $100 \% \mathrm{ESP}_{2}$ & 43,275 & 103,710 \\
\hline Lime production & No fuel use & $\begin{array}{l}\text { High efficiency } \\
\text { deduster }\end{array}$ & $50 \% \mathrm{ESP}_{2}$ & 53,047 & 105,194 \\
\hline $\begin{array}{l}\text { Power \& district } \\
\text { heat plants - new } \\
\text { (excl. coal) }\end{array}$ & Biomass fuels & $\begin{array}{l}\text { High efficiency } \\
\text { deduster }\end{array}$ & $100 \% \mathrm{ESP}_{2}$ & 49,960 & 118,887 \\
\hline $\begin{array}{l}\text { Agglomeration } \\
\text { plant-sinter }\end{array}$ & No fuel use & $\begin{array}{l}\text { High efficiency } \\
\text { deduster }\end{array}$ & $99 \% \mathrm{ESP} 2$ & 91,898 & 205,734 \\
\hline Industrial furnaces & Heavy fuel oil & $\begin{array}{l}\text { High efficiency } \\
\text { deduster }\end{array}$ & $100 \% \mathrm{GP}$ & 217,644 & 208,465 \\
\hline $\begin{array}{l}\text { Power \& district } \\
\text { heat plants - } \\
\text { existing (excl. coal) }\end{array}$ & Biomass fuels & $\begin{array}{l}\text { High efficiency } \\
\text { deduster }\end{array}$ & $100 \% \mathrm{ESP}_{2}$ & 115,573 & 237,774 \\
\hline $\begin{array}{l}\text { Medium boilers } \\
(<1 \mathrm{MW})-\text { manual }\end{array}$ & Fuelwood & $\begin{array}{l}\text { High efficiency } \\
\text { deduster }\end{array}$ & $100 \%$ pellet boilers & 40,028 & 276,275 \\
\hline Heating stoves & Fuelwood & Pellet stove & $21 \%$ new & 284,174 & 63,533 \\
\hline Heating stoves & Fuelwood & Pellet stove & $26 \%$ no control & 284,174 & 284,174 \\
\hline Heating stoves & Fuelwood & Pellet stove & $53 \%$ improved & 284,174 & 382,290 \\
\hline $\begin{array}{l}\text { Power \& district } \\
\text { heat plants - new } \\
\text { (excl. coal) }\end{array}$ & Heavy fuel oil & $\begin{array}{l}\text { High efficiency } \\
\text { deduster }\end{array}$ & $28 \%$ good practice & 422,785 & 403,559 \\
\hline $\begin{array}{l}\text { Agglomeration } \\
\text { plant-sinter }\end{array}$ & No fuel use & Cyclone & $1 \%$ no control & 442,000 & 442,000 \\
\hline Fireplaces & Fuelwood & Improved fireplace & $100 \%$ no control & 707,913 & 707,913 \\
\hline $\begin{array}{l}\text { Other industry } \\
\text { (boilers; liquid and } \\
\text { gaseous fuels) }\end{array}$ & $\begin{array}{l}\text { Derived coal (coke, } \\
\text { briquettes) }\end{array}$ & $\begin{array}{l}\text { High efficiency } \\
\text { deduster }\end{array}$ & $100 \% \mathrm{ESP}_{1}$ & 236,747 & 736,486 \\
\hline $\begin{array}{l}\text { Glass production } \\
\text { (flat, blown, } \\
\text { container glass) }\end{array}$ & No fuel use & $\begin{array}{l}\text { High efficiency } \\
\text { deduster }\end{array}$ & $49 \% \mathrm{ESP}_{2}$ & 352,521 & 788,364 \\
\hline
\end{tabular}




\begin{tabular}{|c|c|c|c|c|c|}
\hline Sector & Fuel & Abatement & $\begin{array}{r}\text { Replacing (\% of } \\
\text { activity data) }\end{array}$ & $\begin{array}{l}\text { Unit cost, } \\
\text { EUR/t BC }\end{array}$ & $\begin{array}{r}\text { Marginal cost, } \\
\text { EUR/t BC }\end{array}$ \\
\hline $\begin{array}{l}\text { Power \& district } \\
\text { heat plants - } \\
\text { existing (excl. coal) }\end{array}$ & Heavy fuel oil & $\begin{array}{l}\text { High efficiency } \\
\text { deduster }\end{array}$ & $28 \%$ good practice & 897,680 & 854,706 \\
\hline Fireplaces & Fuelwood & New fireplace & $40 \%$ improved & $1,073,439$ & $1,164,821$ \\
\hline $\begin{array}{l}\text { Power \& district } \\
\text { heat plants - } \\
\text { existing coal }(<50 \\
\text { MWth) }\end{array}$ & $\begin{array}{l}\text { Brown coal/lignite } \\
\text { grade } 1\end{array}$ & $\begin{array}{l}\text { High efficiency } \\
\text { deduster }\end{array}$ & $98 \% \mathrm{ESP}_{2}$ & 594,719 & 784,148 \\
\hline $\begin{array}{l}\text { Power \& district } \\
\text { heat plants - } \\
\text { existing coal }(<50 \\
\text { MWth) }\end{array}$ & $\begin{array}{l}\text { Brown coal/lignite } \\
\text { grade } 1\end{array}$ & $\begin{array}{l}\text { High efficiency } \\
\text { deduster }\end{array}$ & $2 \% \mathrm{ESP}_{1}$ & 594,719 & $1,674,550$ \\
\hline
\end{tabular}

Table 23: Ranking of BC emission reduction measures (stationary sources) - Sweden

\begin{tabular}{|c|c|c|c|c|c|}
\hline Sector & Fuel & Abatement & $\begin{array}{r}\text { Replacing ( } \% \text { of } \\
\text { activity data) }\end{array}$ & $\begin{array}{l}\text { Unit cost, } \\
\text { EUR/t BC }\end{array}$ & $\begin{array}{r}\text { Marginal cost, } \\
\text { EUR/t BC }\end{array}$ \\
\hline Coke oven & No fuel use & $\begin{array}{l}\text { Electrostatic } \\
\text { precipitator: } 1 \text { field }\end{array}$ & $1 \%$ no control & 622 & 622 \\
\hline $\begin{array}{l}\text { Agricultural waste } \\
\text { burning }\end{array}$ & No fuel use & $\begin{array}{l}\text { Ban on open } \\
\text { burning }\end{array}$ & $100 \%$ no control & 786 & 786 \\
\hline Coke oven & No fuel use & $\begin{array}{l}\text { High efficiency } \\
\text { deduster }\end{array}$ & $50 \% \mathrm{ESP}_{2}$ & 728 & 1,289 \\
\hline Coke oven & No fuel use & $\begin{array}{l}\text { High efficiency } \\
\text { deduster }\end{array}$ & $50 \% \mathrm{ESP}_{1}$ & 728 & 1,810 \\
\hline $\begin{array}{l}\text { Meat frying, food } \\
\text { preparation, BBO }\end{array}$ & No fuel use & $\begin{array}{l}\text { Filters in } \\
\text { households } \\
\text { (kitchen) }\end{array}$ & $100 \%$ No control & 9,100 & 9,100 \\
\hline $\begin{array}{l}\text { Single house } \\
\text { boilers (<50 kW) - } \\
\text { manual }\end{array}$ & Fuelwood & $\begin{array}{l}\text { Biomass single } \\
\text { house boiler new }\end{array}$ & $60 \%$ Improved & 24,064 & 23,609 \\
\hline $\begin{array}{l}\text { Medium boilers } \\
(<50 \mathrm{MW})- \\
\text { automatic }\end{array}$ & Fuelwood & Pellet boiler & $100 \%$ no control & 27,205 & 27,205 \\
\hline $\begin{array}{l}\text { Pig iron, blast } \\
\text { furnace }\end{array}$ & No fuel use & $\begin{array}{l}\text { Electrostatic } \\
\text { precipitator: } 1 \text { field }\end{array}$ & $10 \%$ cyclone & 33,394 & 13,428 \\
\hline $\begin{array}{l}\text { Pig iron, blast } \\
\text { furnace }\end{array}$ & No fuel use & $\begin{array}{l}\text { Electrostatic } \\
\text { precipitator: } 1 \text { field }\end{array}$ & $1 \%$ no control & 33,394 & 33,394 \\
\hline $\begin{array}{l}\text { Single house } \\
\text { boilers }(<50 \mathrm{~kW})- \\
\text { manual }\end{array}$ & Fuelwood & $\begin{array}{l}\text { Biomass single } \\
\text { house boiler- } \\
\text { pellets }\end{array}$ & $100 \%$ NEW & 26,283 & 40,928 \\
\hline Industrial furnaces & Biomass fuels & $\begin{array}{l}\text { High efficiency } \\
\text { deduster }\end{array}$ & $100 \% \mathrm{ESP}_{1}$ & 17,013 & 55,856 \\
\hline $\begin{array}{l}\text { Chemical industry } \\
\text { (boilers) }\end{array}$ & Biomass fuels & $\begin{array}{l}\text { High efficiency } \\
\text { deduster }\end{array}$ & $100 \% \mathrm{ESP}_{1}$ & 26,015 & 86,712 \\
\hline
\end{tabular}




\begin{tabular}{|c|c|c|c|c|c|}
\hline Sector & Fuel & Abatement & $\begin{array}{r}\text { Replacing ( } \% \text { of } \\
\text { activity data) }\end{array}$ & $\begin{array}{l}\text { Unit cost, } \\
\text { EUR/t BC }\end{array}$ & $\begin{array}{r}\text { Marginal cost, } \\
\text { EUR/t BC }\end{array}$ \\
\hline $\begin{array}{l}\text { Other industry } \\
\text { (boilers; liquid and } \\
\text { gaseous fuels) }\end{array}$ & Biomass fuels & $\begin{array}{l}\text { High efficiency } \\
\text { deduster }\end{array}$ & $100 \% \mathrm{ESP}_{1}$ & 26,015 & 86,712 \\
\hline $\begin{array}{l}\text { Paper \& pulp } \\
\text { (boilers) }\end{array}$ & Biomass fuels & $\begin{array}{l}\text { High efficiency } \\
\text { deduster }\end{array}$ & $100 \% \mathrm{ESP}_{1}$ & 26,015 & 86,712 \\
\hline $\begin{array}{l}\text { Fuel conversion - } \\
\text { combustion }\end{array}$ & Heavy fuel oil & $\begin{array}{l}\text { High efficiency } \\
\text { deduster }\end{array}$ & $\begin{array}{l}100 \% \text { Good } \\
\text { practice }\end{array}$ & 133,127 & 124,131 \\
\hline Industrial furnaces & Heavy fuel oil & $\begin{array}{l}\text { High efficiency } \\
\text { deduster }\end{array}$ & $\begin{array}{r}100 \% \text { Good } \\
\text { practice }\end{array}$ & 133,127 & 124,131 \\
\hline $\begin{array}{l}\text { Pig iron, blast } \\
\text { furnace }\end{array}$ & No fuel use & $\begin{array}{l}\text { High efficiency } \\
\text { deduster }\end{array}$ & $10 \% \mathrm{ESP}_{1}$ & 43,275 & 144,645 \\
\hline $\begin{array}{l}\text { Power \& district } \\
\text { heat plants - new } \\
\text { (excl. coal) }\end{array}$ & Heavy fuel oil & $\begin{array}{l}\text { High efficiency } \\
\text { deduster }\end{array}$ & $\begin{array}{r}57.7 \% \text { Good } \\
\text { practice }\end{array}$ & 209,042 & 177,090 \\
\hline $\begin{array}{l}\text { Power \& district } \\
\text { heat plants - new } \\
\text { (excl. coal) }\end{array}$ & Biomass fuels & $\begin{array}{l}\text { High efficiency } \\
\text { deduster }\end{array}$ & $100 \% \mathrm{ESP}_{1}$ & 55,611 & 182,432 \\
\hline $\begin{array}{l}\text { Transformation } \\
\text { sector (boilers) }\end{array}$ & Heavy fuel oil & $\begin{array}{l}\text { High efficiency } \\
\text { deduster }\end{array}$ & $78 \%$ Good practice & 231,146 & 217,519 \\
\hline $\begin{array}{l}\text { Other industry } \\
\text { (boilers; liquid and } \\
\text { gaseous fuels) }\end{array}$ & Heavy fuel oil & $\begin{array}{l}\text { High efficiency } \\
\text { deduster }\end{array}$ & $78 \%$ Good practice & 231,146 & 217,519 \\
\hline $\begin{array}{l}\text { Paper \& pulp } \\
\text { (boilers) }\end{array}$ & Heavy fuel oil & $\begin{array}{l}\text { High efficiency } \\
\text { deduster }\end{array}$ & $78 \%$ Good practice & 231,146 & 217,519 \\
\hline $\begin{array}{l}\text { Power \& district } \\
\text { heat plants - } \\
\text { existing (excl. coal) }\end{array}$ & Biomass fuels & $\begin{array}{l}\text { High efficiency } \\
\text { deduster }\end{array}$ & $100 \% \mathrm{ESP}_{1}$ & 67,413 & 224,662 \\
\hline $\begin{array}{l}\text { Pig iron, blast } \\
\text { furnace }\end{array}$ & No fuel use & $\begin{array}{l}\text { Electrostatic } \\
\text { precipitator: } 2 \\
\text { fields }\end{array}$ & $1 \% \mathrm{ESP}_{1}$ & 39,465 & 226,930 \\
\hline $\begin{array}{l}\text { Power \& district } \\
\text { heat plants - } \\
\text { existing (excl. coal) }\end{array}$ & Heavy fuel oil & $\begin{array}{l}\text { High efficiency } \\
\text { deduster }\end{array}$ & $62 \%$ Good practice & 269,754 & 228,996 \\
\hline $\begin{array}{l}\text { Medium boilers } \\
(<50 \mathrm{MW})- \\
\text { automatic }\end{array}$ & Fuelwood & $\begin{array}{l}\text { High efficiency } \\
\text { deduster }\end{array}$ & $100 \%$ pellet boiler & 51,385 & 247,382 \\
\hline $\begin{array}{l}\text { Industry: Other } \\
\text { combustion, } \\
\text { pulverized }\end{array}$ & Hard coal, grade 1 & $\begin{array}{l}\text { High efficiency } \\
\text { deduster }\end{array}$ & $50 \% \mathrm{ESP}_{2}$ & 162,833 & 271,501 \\
\hline Heating stoves & Fuelwood & Pellet stove & $50 \%$ new & 330,144 & 101,774 \\
\hline Heating stoves & Fuelwood & Pellet stove & $50 \%$ improved & 330,144 & 306,555 \\
\hline $\begin{array}{l}\text { Paper \& pulp } \\
\text { (boilers) }\end{array}$ & Hard coal, grade 1 & $\begin{array}{l}\text { High efficiency } \\
\text { deduster }\end{array}$ & $50 \% \mathrm{ESP}_{2}$ & 214,343 & 414,840 \\
\hline $\begin{array}{l}\text { Other industry } \\
\text { (large coal boilers; } \\
>50 \mathrm{MWth} \text { ) }\end{array}$ & Hard coal, grade 1 & $\begin{array}{l}\text { High efficiency } \\
\text { deduster }\end{array}$ & $50 \% \mathrm{ESP}_{2}$ & 217,243 & 414,840 \\
\hline
\end{tabular}




\begin{tabular}{l|l|rrr} 
Sector & Fuel & Abatement & $\begin{array}{r}\text { Replacing (\% of } \\
\text { activity data) }\end{array}$ & $\begin{array}{r}\text { Unit cost, } \\
\text { EUR/t BC }\end{array}$ \\
$\begin{array}{l}\text { Glass production } \\
\text { (flat, blown, } \\
\text { container glass) }\end{array}$ & No fuel use & $\begin{array}{l}\text { High efficiency } \\
\text { deduster }\end{array}$ & $49 \%$ ESP2 & 352,521 \\
$\begin{array}{l}\text { Cement } \\
\text { production }\end{array}$ & No fuel use & $\begin{array}{l}\text { High efficiency } \\
\text { deduster }\end{array}$ & $35 \%$ ESP2 & 290,269 \\
\hline
\end{tabular}





\section{Annex 10. Transboundary effects from the implementation of MFR scenarios}

Relative changes in population-weighted $\mathrm{PM}_{2.5}$ concentrations, a corresponding increase in average life expectancy (Life Years Gained) and the monetary valuation of health effects (including morbidity). In columns - countries where MFR is implemented, in rows - countries where the effects are noticeable.

Table 24: Population-weighted concentrations of $\mathrm{PM}_{2.51} \mu \mathrm{g} / \mathrm{m}^{3}$

\begin{tabular}{|c|c|c|c|c|c|c|}
\hline & Belarus & Denmark & Finland & Sweden & $\begin{array}{l}3 \text { Nordic } \\
\text { countries }\end{array}$ & $\begin{array}{r}3 \text { Nordic countries } \\
+ \text { Belarus }\end{array}$ \\
\hline Belarus & 0.598 & 0.001 & 0.001 & 0.001 & 0.001 & 0.599 \\
\hline Denmark & - & 0.443 & - & 0.019 & 0.462 & 0.463 \\
\hline Finland & 0.010 & 0.001 & 0.471 & 0.011 & 0.482 & 0.492 \\
\hline Sweden & 0.004 & 0.021 & 0.003 & 0.163 & 0.187 & 0.191 \\
\hline $\begin{array}{l}\text { Countries } \\
\text { outside the } \\
\text { Nordic } \\
\text { community } \\
\text { that would } \\
\text { benefit from } \\
\text { MFR } \\
\text { emission } \\
\text { reductions }\end{array}$ & $\begin{array}{r}\text { Estonia, } \\
\text { Lithuania, } \\
\text { Latvia, Moldova, } \\
\text { Poland, } \\
\text { Romania, } \\
\text { Russian } \\
\text { Federation, } \\
\text { Ukraine }\end{array}$ & $\begin{array}{r}\text { Estonia, } \\
\text { Lithuania, } \\
\text { Latvia, } \\
\text { Netherlands, } \\
\text { Poland, } \\
\text { Germany }\end{array}$ & $\begin{array}{r}\text { Estonia, } \\
\text { Lithuania, } \\
\text { Latvia, } \\
\text { Russian } \\
\text { Federation }\end{array}$ & $\begin{array}{r}\text { Estonia, } \\
\text { Lithuania, } \\
\text { Latvia }\end{array}$ & $\begin{array}{r}\text { Estonia, } \\
\text { Lithuania, } \\
\text { Latvia, } \\
\text { Netherlands, } \\
\text { Poland, } \\
\text { Germany, } \\
\text { Russian } \\
\text { Federation }\end{array}$ & $\begin{array}{r}\text { Estonia, Lithuania, } \\
\text { Latvia, } \\
\text { Netherlands, } \\
\text { Poland, Germany, } \\
\text { Russian } \\
\text { Federation, } \\
\text { Romania, Moldova, } \\
\text { Ukraine }\end{array}$ \\
\hline
\end{tabular}

Table 25: Changes in average life expectancy, Life Years Gained (VOLY approach)

\begin{tabular}{|c|c|c|c|c|c|c|}
\hline & Belarus & Denmark & Finland & Sweden & $\begin{array}{l}3 \text { Nordic } \\
\text { countries }\end{array}$ & $\begin{array}{r}3 \text { Nordic countries } \\
+ \text { Belarus }\end{array}$ \\
\hline Belarus & 4,317 & 7 & 7 & 7 & 7 & 4,324 \\
\hline Denmark & - & 1,601 & - & 69 & 1,670 & 1,673 \\
\hline Finland & 36 & 3 & 1,562 & 36 & 1,598 & 1,631 \\
\hline Sweden & 23 & 122 & 17 & 948 & 1,087 & 1,111 \\
\hline Nordic countries* & 56 & 1,736 & 1,579 & 1,072 & 4,383 & 4,446 \\
\hline Other Europe & 3,987 & 232 & 141 & 19 & 420 & 4,436 \\
\hline Europe, total & 8,360 & 1,975 & 1,728 & 1,097 & 4,810 & 13,207 \\
\hline
\end{tabular}

Note: * Here - including even Norway. 
Table 26: Valuation of health effects (mortality valued in VOLY), MEuro

\begin{tabular}{|c|c|c|c|c|c|c|}
\hline & Belarus & Denmark & Finland & Sweden & $\begin{array}{l}3 \text { Nordic } \\
\text { countries }\end{array}$ & $\begin{array}{r}3 \text { Nordic countries } \\
+ \text { Belarus }\end{array}$ \\
\hline Belarus & 314.7 & 0.5 & 0.5 & 0.5 & 0.5 & 315.3 \\
\hline Denmark & & 125.5 & & 5.4 & 130.9 & 131.1 \\
\hline Finland & 2.6 & 0.3 & 123.8 & 2.9 & 126.7 & 129.3 \\
\hline Sweden & 1.9 & 9.8 & 1.4 & 75.9 & 87.0 & 88.9 \\
\hline Nordic countries* & 4.5 & 136.3 & 125.2 & 85.7 & 346.9 & 351.9 \\
\hline Other Europe & 292.3 & 18.4 & 10.3 & 1.4 & 32.3 & 326.8 \\
\hline Europe, total & 611.5 & 155.2 & 136.0 & 87.6 & 379.6 & 993.9 \\
\hline
\end{tabular}

Note: * Here - including even Norway.

Table 27: Valuation of health effects (mortality valued in VSL based on avoided fatalities), MEuro

\begin{tabular}{lrrrrrr} 
& Belarus & Denmark & Finland & Sweden & $\begin{array}{r}\text { 3 Nordic } \\
\text { countries }\end{array}$ & $\begin{array}{r}3 \text { Nordic countries } \\
+ \text { Belarus }\end{array}$ \\
Belarus & 1,082 & 2 & 2 & 2 & 2 & 1,084 \\
Denmark & - & 440 & - & 19 & 459 & 460 \\
Finland & 10 & 1 & 459 & 11 & 470 & 480 \\
Sweden & 6 & 34 & 5 & 262 & 301 & 307 \\
Nordic countries* & 16 & 477 & 464 & 296 & 1,236 & 1,254 \\
Other Europe & 1,002 & 72 & 35 & 5 & 119 & 1,129 \\
Europe, total & 2,100 & 550 & 501 & 303 & 1,357 & 3,467 \\
\hline
\end{tabular}

Note: * Here - including even Norway. 
Nordic Council of Ministers

Nordens Hus

Ved Stranden 18

DK-1061 Copenhagen $\mathrm{K}$

www.norden.org

\section{Particle emissions in Belarus and in the Nordic countries}

The overall goal of the project is to stimulate decision-makers in Belarus to prioritize abatement measures aimed at black carbon in their efforts to reduce emissions of PM2.5, as encouraged in the Gothenburg protocol under the UNECE CLRTAP. To reach this purpose and in order to build up scientific basis necessary for further policy development, a comprehensive analysis of PM2.5 and BC emissions, emission reduction potentials and cost-effective abatement measures in Belarus has been conducted.

The report presents two main parts of the conducted analysis: a part focused on the emission inventories, and a part summarizing the results of the integrated assessment modelling. The main focus is on analysis for Belarus; however, a range of modelling results have been obtained for the three participating Nordic countries - Denmark, Finland and Sweden. 